\title{
Make a difference to your profession and become a CJNS reviewer
}

The Canadian Journal of Neurological Sciences (CJNS) is always looking for talented and skilled reviewers to submit timely and high quality reviews of manuscripts. Without these volunteers, the journal cannot maintain a steady stream of high quality, informational articles relevant to readers.

Reviewing for CJNS supports Canadian clinical neurosciences. Make it your top refereeing priority.

The Benefits of Becoming a Reviewer:

- An annual record of all your refereeing contributions for academic promotional purposes.

- Your name included in the "Thank you to Reviewers" list in the February issue of CJNS.

- Eligibility for the "Distinguished Reviewer of the Year" award, recognizing extensive, timely and high quality reviews.

- Reviewers who regularly contribute to the CINS are considered for the editorial board.

- Credits towards your Maintenance of Certification.

- Serving as a CINS reviewer supports your journal and Canadian clinical neurosciences.

cut here

Please fill out the form below and mail to the Canadian Journal of Neurological Sciences, \#709 - 7015 Macleod Trail SW, Calgary, AB T2H $2 \mathrm{~K} 6$ CANADA or fax to (403) 229-166r.

A CJNS representative will contact you as soon as a manuscript requiring your expertise becomes available.

Name:

(PLEASE PRINT)

Address:

City:

Postal Code:

Phone:

Area(s) of expertise:

Brief training background:

Current academic position:
Province:

Email:

Fax: 


\section{$\aleph^{*}$ Rebif $44_{\operatorname{mgx} 3}$}

$22 \mathrm{mcg} / 0.5 \mathrm{~mL}$ and $44 \mathrm{mcg} / 0.5 \mathrm{~mL}$ liquid formulation for injection

\section{THERAPEUTIC CLASSIFICATION:}

mmunomodulato

\section{INDICATIONS AND CLINICAL USE:}

Multiple Sclerosis: Rebif is indicated for the treatment of relapsing forms of multiple sclerosis, to reduce the number and severity of clinical exacerbations, slow the progression of physical disability, reduce the requirement for steroids, and reduce the number of hospitalizations for treatment of multiple sclerosis and reduction in T.-Gd enhanced and T, (burden of disease) as seen on MRI. Relapsing forms of multiple sclerosis include the subgroups of MS in which patients still experience recurrent attacks of neurological dysfunction including traditional RRMS but also SPMS

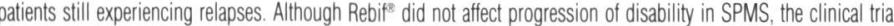
has shown that secondary progressive MS patients who still experience relapses, had a statistically significan improvement on relapse rate and on MRI measures of disease activity as compared to patients on placebo. Rebif has not yet been investigated in patients with primary progressive multiple sclerosis and should not be administered to such patients.

\section{CONTRAINDICATIONS:}

Rebif (Interferon beta-1a) is contraindicated in patients with a known hypersensitivity to natural or recombinan interferon beta, albumin (human), or any other component of the formulation. Rebif is is contraindicated in pregnant patients (see WARNINGS)

\section{WARNINGS:}

Rebif (Interferon beta-1a) should be used under the supervision of a physician. The first injection should be performed under the supervision of an appropriately qualified health care professional

Relapsing forms of Multiple Sclerosis: Depression: Depression and suicidal ideation are known to occur in increased frequency in the multiple sclerosis population and in association with interferon use, including Rebifs Some association of increased depression has been noted with interferon use. However, clinical trial data with Rebif has not shown an increase in depression compared to placebo-treated patients. Patients treated with Rebit should be advised to immediately report any symptoms of depression and/or suicidal ideation to their prescribing physician. Patients exhibiting depression should be monitored closely during therapy with Rebif ${ }^{ \pm}$and treated appropriately. Cessation 0 therapy with Interferon beta-1a should be considered. Hepatic Injury: Isolated, life-threatening cases of acute hepatic failure have been reported with Rebif therapy Symptomatic hepatic dysfunction, primarily presenting as jaundice, has been reported as a rare complication of Rebif ${ }^{8}$ use. Several possible mechanisms may explain the effect of Rebit on the liver (including direct toxicity, indirect toxicity via release of cytokines and/or autoimmunity). Asymptomatic elevations of transaminases (particularly ALT) is common with interferon therapy (see ADVERSE REACTIONS). Dose reduction or discontinuation should be considered if ALT rises 5 times above the ULN. Anaphylaxis: Anaphylaxis has been reported as a rare complication of Rebif ${ }^{\circledR}$ use. Other allergic reactions have included skin rash, angioedema, an urticaria and have ranged from mild to severe without a clear relationship to dose or duration of exposure. Several allergic reactions, some severe, have occurred after prolonged use. Pregnancy and Lactation: Rebif should not be administered in case of pregnancy and lactation. There are no adequate and well-controlled studies of Rebifer in pregnant women. In the clinical trials there were 2 spontaneous abortions observed and 5 fetuses carried to term among 7 women in the Rebif ${ }^{8}$ groups. There have been cases of spontaneous abortion in the post-marketing setting. In cynomolgous monkeys administered doses approximately 2 times the cumulative weekly human dose (based on eithe body weight or surface area), Rebit" treatment has been associated with significant increases in embryolethal or abortifacient effects either during the period of organogenesis (gestation day 21-89) or later in pregnancy. There were no fetal malformations or other evidence of teratogenesis noted in these studies; however, it is not known if teratogenic effects exist in humans. These effects are consistent with the abortifacient effects of other type I interferons. Patients should be advised about the abortifacient potential of Rebif ${ }^{\star}$. Fertile women receiving Rebif ${ }^{\circledast}$ should be advised to take adequate contraceptive measures. It is not known if interferons alter the efficacy of ora contraceptives. Patients planning for pregnancy and those becoming pregnant should be informed of the potentia hazards of interferons to the foetus and Rebif ${ }^{\text {s. }}$ should be discontinued (see CONTRAINDICATIONS and also PRECAUTIONS: Information to be provided to the patient). It is not known whether Rebit is excreted in human milk. Because of the potential for serious adverse reactions in nursing infants, a decision should be made either to discontinue nursing or to discontinue Rebit ${ }^{3}$ therapy. Cardiac Disease: Patients with cardiac disease, such as angina, congestive heart failure or arrhythmia, should be closely monitored for worsening of their clinical condition during initiation and continued therapy with Rebif*. Symptoms of the flu-like syndrome associated with Rebif may prove stressful to patients with cardiac conditions.

\section{PRECAUTIONS:}

General: Patients should be informed of the most common adverse reactions associated with interferon beta administration, including symptoms of the flu-like syndrome (see ADVERSE REACTIONS). These symptoms tend to be most prominent at the initiation of therapy and decrease in frequency and severity with continued treatment Caution should be exercised when administering Rebifs (Interferon beta-1a) to patients with pre-existing seizures disorder. For patients without a pre-existing seizure disorder who develop seizures during therapy, an etiologic basis should be stablished and appropriate anti-convulsant therapy instituted prior to continuing treatment with Rebif*. The effect of Rebif ${ }^{\oplus}$ administration on the medical management of patients with seizure disorder is unknown. Serum neutralising antibodies against Rebif ${ }^{*}$ may develop. The precise incidence and clinical significance of antibodies is as yet uncertain See ADVERSE REACTIONS). Pediatric use: There is no controlled clinical experience with Rebife in children unde 16 years of age with multiple sclerosis and therefore Rebifs should not be used in this population. Patients with Special Diseases and Conditions: Caution should be used and close monitoring considered when administering Rebits to patients with severe renal failure, patients with severe myelosuppression, and patients with cardiac disease (see WARNINGS). Drug Interaction: No formal drug interaction studies have been conducted with Rebif in humans. Interferons have been reported to reduce the activity of hepatic cytochrome $\mathrm{p}_{450}$-dependent enzymes in humans and animals. Caution should be exercised when administering Rebife in combination with medicinal products that have a narrow therapeutic index and are largely dependent on the hepatic cytochrome $p_{450}$ system for clearance, e.g. antiepileptics and some classes of antidepressants. The interaction of Rebif with corticosteroids or ACTH has not been studied systematically. Clinical studies indicate that multiple sclerosis patients can receive Rebif ${ }^{8}$ and corticosteroids or ACTH during relapses. Rebifs should not be mixed with other drugs in the same syringe. Laboratory Tests: Relapsing forms of multiple sclerosis: Laboratory abnormalities are associated with the use of interferons Therefore, in addition to those laboratory tests normally required for monitoring patients with multiple sclerosis, liver enzymes should be monitored at baseline, every month for the first 6 months and every 6 months thereafter (see WARNINGS). Complete and differential white blood cell counts, platelet counts and blood chemistries are also recommended during Rebif therapy. These tests should be performed at baseline, months 1.3 and 6 , and every 6 months thereafter. Patients being treated with interferon beta may occasionally develop new or worsening thyroid abnormalities. Thyroid testing should be performed at baseline and every 6 months. In case of abnormal results or in patients with a past history of thyroid dysfunction, any necessary treatment and more frequent testing should be performed as clinically indicated (see ADVERSE REACTIONS)

\section{ADVERSE REACTIONS:}

Multiple Sclerosis: As with other interferon preparations, flu-like symptoms are not uncommon. The use of interferon beta may cause flu-like syndrome, asthenia, pyrexia, chills, arthralgia, myalgia, headache, and injection site reactions. Less frequent adverse reactions include cold sores, stuffy nose, light headedness, mucosal irritation, haematological disorders (leukopenia, lymphopenia, granulocytopenia), and alterations in liver function tests such as elevated AST and ALT. These effects are usually mild and reversible. Fever and flu-like symptoms can be treated with acetaminophen or ibuprofen. Depending on the severity and persistence of the side-effects, the dose may be lowered or temporarily interrupted, at the discretion of the physician. Most injection site reactions are mild to moderate. Allergic reactions, such as pruritus, rash, erythematous rash and maculo-papular rash may occur. Cases of skin ulceration/necrosis at the site of injection have been reported with long term treatment. Anaphylaxis has also been observed with the use of Rebif' (see WARNINGS). Serious adverse hepatic reactions such as hepatitis, with or without jaundice, have been rarely reported and isolated cases of acute hepatic failure have been reported (see WARNINGS). Occasional thyroid dysfunction, generally transient and mild, may occur during the first year of treatment, particularly in patients with pre-existing thyroiditis (see PRECAUTIONS: Laboratory Tests). The adverse events experienced during the first two years of the PRISMS study are listed below, by WHOART System Organ Class. The most common amongst the injection site reactions was in the form of mild erythema. The majority of the other injection site reactions were also mild in the 2 Rebif ${ }^{8}$ groups. Necrosis was reported in 8 patients treated with Rebif?. Two of these patients were in the $66 \mathrm{mcg}$ weekly and six in the $132 \mathrm{mcg}$ weekly groups. All patients completed the planned treatment period, with only 1 requiring temporary dose reductions and another patient stopping treatment for 2 weeks. Those that required treatment, received antibiotics.

Proportion of Patients Enrolled in the PRISMS study Reporting Adverse Events During Years 1 and 2 of Treatment

\begin{tabular}{|c|c|c|c|c|}
\hline Body System & $\begin{array}{l}\text { Preferred } \\
\text { term }\end{array}$ & Placebo & $\begin{array}{l}\text { Rebif }^{*} 66 \mathrm{mcg} \\
\text { weekly }\end{array}$ & $\begin{array}{c}\text { Rebif }^{\oplus} 132 \mathrm{mcg} \\
\text { weekly }\end{array}$ \\
\hline $\begin{array}{l}\text { Application site } \\
\text { disorders }\end{array}$ & $\begin{array}{l}\text { Injection site } \\
\text { inflammation (a)(b) } \\
\text { Injection site reaction (a)(b) } \\
\text { Injection site pain (b) }\end{array}$ & $\begin{array}{l}15.0 \% \\
13.4 \% \\
14.4 \%\end{array}$ & $\begin{array}{l}65.6 \% \\
31.2 \% \\
20.1 \%\end{array}$ & $\begin{array}{l}65.8 \% \\
\\
34.8 \% \\
22.8 \%\end{array}$ \\
\hline $\begin{array}{l}\text { Body as a whole - } \\
\text { general disorders }\end{array}$ & $\begin{array}{l}\text { Influenza-like symptoms } \\
\text { Fatigue } \\
\text { Fever (a)(b) } \\
\text { Leg pain } \\
\text { Rigors(b)(c) }\end{array}$ & $\begin{array}{r}51.3 \% \\
35.8 \% \\
15.5 \% \\
14.4 \% \\
5.3 \% \\
\end{array}$ & $\begin{array}{r}56.1 \% \\
32.8 \% \\
24.9 \% \\
10.1 \% \\
6.3 \%\end{array}$ & $\begin{array}{l}58.7 \% \\
41.3 \% \\
27.7 \% \\
13.0 \% \\
13.0 \%\end{array}$ \\
\hline $\begin{array}{l}\text { Centr. \& periph. } \\
\text { nervous system } \\
\text { disorders }\end{array}$ & $\begin{array}{l}\text { Headache } \\
\text { Diziness } \\
\text { Paraesthesia } \\
\text { Hypoaesthesia }\end{array}$ & $\begin{array}{l}62.6 \% \\
17.6 \% \\
18.7 \% \\
12.8 \%\end{array}$ & $\begin{array}{l}64.6 \% \\
14.3 \% \\
19.6 \% \\
12.2 \%\end{array}$ & $\begin{array}{r}70.1 \% \\
16.3 \% \\
16.3 \% \\
7.6 \%\end{array}$ \\
\hline $\begin{array}{l}\text { Respiratory } \\
\text { system disorders }\end{array}$ & $\begin{array}{l}\text { Rhinitis } \\
\text { Upper Resp Tract Infection } \\
\text { Pharyngitis (b) } \\
\text { Coughing } \\
\text { Bronchitis }\end{array}$ & $\begin{array}{r}59.9 \% \\
32.6 \% \\
38.5 \% \\
21.4 \% \\
9.6 \%\end{array}$ & $\begin{array}{l}52.4 \% \\
36.0 \% \\
34.9 \% \\
14.8 \% \\
10.6 \%\end{array}$ & $\begin{array}{r}50.5 \% \\
29.3 \% \\
28.3 \% \\
19.0 \% \\
9.2 \%\end{array}$ \\
\hline $\begin{array}{l}\text { Gastro-intestinal } \\
\text { system disorders }\end{array}$ & $\begin{array}{l}\text { Nausea } \\
\text { Abdominal pain } \\
\text { Diarrhoea } \\
\text { Vomiting }\end{array}$ & $\begin{array}{l}23.0 \% \\
17.1 \% \\
18.7 \% \\
12.3 \%\end{array}$ & $\begin{array}{l}24.9 \% \\
22.2 \% \\
17.5 \% \\
12.7 \%\end{array}$ & $\begin{array}{l}24.5 \% \\
19.6 \% \\
19.0 \% \\
12.0 \%\end{array}$ \\
\hline $\begin{array}{l}\text { Musculo-skeletal } \\
\text { system disorders }\end{array}$ & $\begin{array}{l}\text { Back pain } \\
\text { Myalgia } \\
\text { Arthralgia } \\
\text { Skeletal pain }\end{array}$ & $\begin{array}{l}19.8 \% \\
19.8 \% \\
17.1 \% \\
10.2 \%\end{array}$ & $\begin{array}{l}23.3 \% \\
24.9 \% \\
15.3 \% \\
14.8 \%\end{array}$ & $\begin{array}{r}24.5 \% \\
25.0 \% \\
19.0 \% \\
9.8 \%\end{array}$ \\
\hline $\begin{array}{l}\text { Psychiatric } \\
\text { disorders }\end{array}$ & $\begin{array}{l}\text { Depression } \\
\text { Insomnia }\end{array}$ & $\begin{array}{l}27.8 \% \\
21.4 \%\end{array}$ & $\begin{array}{l}20.6 \% \\
19.6 \%\end{array}$ & $\begin{array}{l}23.9 \% \\
23.4 \%\end{array}$ \\
\hline $\begin{array}{l}\text { White cell \& res. } \\
\text { disorders }\end{array}$ & $\begin{array}{l}\text { Lymphopenia (a)(b) } \\
\text { Leucopenia (a)(b)(c) } \\
\text { Granulocytopenia (a)(b) } \\
\text { Lymphadenopathy }\end{array}$ & $\begin{array}{l}11.2 \% \\
3.7 \% \\
3.7 \% \\
8.0 \%\end{array}$ & $\begin{array}{l}20.1 \% \\
12.7 \% \\
11.6 \% \\
11.1 \%\end{array}$ & $\begin{array}{l}28.8 \% \\
22.3 \% \\
15.2 \% \\
12.0 \%\end{array}$ \\
\hline $\begin{array}{l}\text { Skin \& } \\
\text { appendages } \\
\text { disorders }\end{array}$ & Pruritus & $11.8 \%$ & $9.0 \%$ & $12.5 \%$ \\
\hline $\begin{array}{l}\text { Liver \& biliary } \\
\text { system disorders }\end{array}$ & $\begin{array}{l}\text { ALT increased (a)(b) } \\
\text { AST increased (a)(b)(c) }\end{array}$ & $\begin{array}{l}4.3 \% \\
3.7 \%\end{array}$ & $\begin{array}{l}19.6 \% \\
10.1 \%\end{array}$ & $\begin{array}{l}27.2 \% \\
17.4 \%\end{array}$ \\
\hline $\begin{array}{l}\text { Urinary system } \\
\text { disorders }\end{array}$ & Urinary tract infection & $18.7 \%$ & $18.0 \%$ & $16.8 \%$ \\
\hline Vision disorders & Vision abnormal & $7.0 \%$ & $7.4 \%$ & $13.0 \%$ \\
\hline Secondary terms & Fall & $16.0 \%$ & $16.9 \%$ & $15.8 \%$ \\
\hline
\end{tabular}

(a) Significant difference between placebo and Rebif 66 mcg weekly groups ( $p \leq 0.05$

(b) Significant difference between placebo and Rebif $132 \mathrm{mcg}$ weekly groups ( $\mathrm{p} \leq 0.05$

(c) Significant difference between Rebif 66 mcg and Rebif $132 \mathrm{mcg}$ weekly groups $(p \leq 0.05)$

In addition to the above listed adverse events, the following events have been experienced less frequently, in one or both of the relapsing-remitting multiple sclerosis studies: asthenia, fluid retention, anorexia, gastroenteritis, heartburn, paradentium affections, dental abcess or extraction, stomatitis, glossitis, sleepiness, anxiety, irritability, confusion, lymphadenopathy, weight gain, bone fracture, dyspnoea, cold sores, fissure at the angle of the mouth, menstrua disorders, cystitis, vaginitis. After 2 years, the placebo patients were switched to Rebif ${ }^{8}$, and along with the patients for the Rebif treatment groups, they were treated for an additional two years. Listed below by WHOART System Organ Class, are the proportion of patients reporting the most common adverse events during years 3 and 4 of treatment. The results are similar to those obtained in the original phase of the study. The findings indicate that the incidence of interferon-related adverse events diminishes somewhat with continued exposure to the medication. Cases of necrosis were rare and not a cause of drop-out. For Rebif ${ }^{\check{z}} 66$ mcg weekly, there was one episode of skin necrosis per 92 years of exposure or per 14,100 injections. The comparable figures for Rebif* $132 \mathrm{mcg}$ weekly are 1 episode of necrosis per 61 years of exposure or per 9,300 injections. 
Proportion of Patients Reporting the Most Common Adverse Events During Years 3 and 4 of Treatment

\begin{tabular}{|c|c|c|c|c|c|}
\hline Body system & $\begin{array}{l}\text { Preferred } \\
\text { term }\end{array}$ & $\begin{array}{c}\text { Placebo/66 } \\
(n=85)\end{array}$ & $\begin{array}{c}\text { Placebo/132 } \\
(n=87)\end{array}$ & $\begin{array}{l}\text { Rebife } 66 \mathrm{mcg} \\
\text { weekly }(\mathrm{n}=167)\end{array}$ & $\begin{array}{l}\text { Rebif" } 132 \mathrm{mcg} \\
\text { weekly (n=167) }\end{array}$ \\
\hline \multirow{2}{*}{$\begin{array}{l}\text { Application site } \\
\text { disorders }\end{array}$} & \multirow{2}{*}{$\begin{array}{l}\text { Injection site } \\
\text { inflammation } \\
\text { Injection site reaction } \\
\text { Injection site pain }\end{array}$} & $65.9 \%$ & $65.5 \%$ & $56.9 \%$ & $66.5 \%$ \\
\hline & & $\begin{array}{l}28.2 \% \\
18.8 \% \\
\end{array}$ & $\begin{array}{l}37.9 \% \\
21.8 \% \\
\end{array}$ & $\begin{array}{l}29.9 \% \\
15.0 \% \\
\end{array}$ & $\begin{array}{l}31.7 \% \\
13.8 \%\end{array}$ \\
\hline \multirow{2}{*}{$\begin{array}{l}\text { Body as a whole - } \\
\text { general disorders }\end{array}$} & \multirow{2}{*}{$\begin{array}{l}\text { Influenza-like } \\
\text { symptoms } \\
\text { Fatigue } \\
\text { Fever } \\
\text { Leg pain } \\
\text { Trauma } \\
\text { Hypertonia } \\
\text { Pain }\end{array}$} & $42.4 \%$ & $60.9 \%$ & $50.3 \%$ & $42.5 \%$ \\
\hline & & $\begin{array}{r}34.1 \% \\
14.1 \% \\
8.2 \% \\
15.3 \% \\
14.1 \% \\
4.7 \%\end{array}$ & $\begin{array}{r}36.8 \% \\
14.9 \% \\
12.6 \% \\
5.7 \% \\
11.5 \% \\
14.9 \%\end{array}$ & $\begin{array}{r}24.6 \% \\
15.6 \% \\
6.6 \% \\
14.4 \% \\
10.8 \% \\
4.2 \%\end{array}$ & $\begin{array}{r}27.5 \% \\
12.0 \% \\
7.8 \% \\
11.4 \% \\
9.6 \% \\
4.2 \%\end{array}$ \\
\hline $\begin{array}{l}\text { Centr. \& periph. } \\
\text { nervous system } \\
\text { disorders }\end{array}$ & $\begin{array}{l}\text { Headache } \\
\text { Dizziness } \\
\text { Paraesthesia } \\
\text { Hypoaesthesia }\end{array}$ & $\begin{array}{r}44.7 \% \\
4.7 \% \\
15.3 \% \\
7.1 \% \\
\end{array}$ & $\begin{array}{l}55.2 \% \\
11.5 \% \\
13.8 \% \\
13.8 \% \\
\end{array}$ & $\begin{array}{l}46.7 \% \\
13.2 \% \\
10.2 \% \\
7.2 \% \\
\end{array}$ & $\begin{array}{l}46.7 \% \\
12.6 \% \\
7.8 \% \\
9.0 \% \\
\end{array}$ \\
\hline \multirow[t]{2}{*}{$\begin{array}{l}\text { Respiratory } \\
\text { system disorders }\end{array}$} & \multirow{2}{*}{$\begin{array}{l}\text { Rhinitis } \\
\text { Upper Resp Tract } \\
\text { Infection } \\
\text { Pharyngitis } \\
\text { Coughing } \\
\text { Sinusitis }\end{array}$} & $\begin{array}{l}38.8 \% \\
18.8 \%\end{array}$ & $\begin{array}{l}29.9 \% \\
14.9 \%\end{array}$ & $\begin{array}{l}39.5 \% \\
22.8 \%\end{array}$ & $\begin{array}{l}33.5 \% \\
20.4 \%\end{array}$ \\
\hline & & $\begin{array}{r}23.5 \% \\
5.9 \% \\
8.2 \%\end{array}$ & $\begin{array}{l}12.6 \% \\
11.5 \% \\
11.5 \%\end{array}$ & $\begin{array}{l}19.8 \% \\
8.4 \% \\
5.4 \%\end{array}$ & $\begin{array}{l}15.0 \% \\
13.8 \% \\
10.2 \%\end{array}$ \\
\hline $\begin{array}{l}\text { Gastro-intestinal } \\
\text { system disorders }\end{array}$ & $\begin{array}{l}\text { Nausea } \\
\text { Abdominal pain } \\
\text { Diarrnoea } \\
\text { Constipation }\end{array}$ & $\begin{array}{r}12.9 \% \\
8.2 \% \\
5.9 \% \\
14.1 \% \\
\end{array}$ & $\begin{array}{l}19.5 \% \\
16.1 \% \\
8.0 \% \\
9.2 \% \\
\end{array}$ & $\begin{array}{l}10.8 \% \\
13.2 \% \\
12.0 \% \\
6.0 \% \\
\end{array}$ & $\begin{array}{l}11.4 \% \\
10.8 \% \\
9.0 \% \\
7.2 \% \\
\end{array}$ \\
\hline $\begin{array}{l}\text { Musculo-skeletal } \\
\text { system disorders }\end{array}$ & $\begin{array}{l}\text { Back pain } \\
\text { Myalgia } \\
\text { Arthralgia } \\
\text { Muscle weakness } \\
\text { Skeletal pain }\end{array}$ & $\begin{array}{l}14.1 \% \\
21.2 \% \\
16.5 \% \\
12.9 \% \\
8.2 \%\end{array}$ & $\begin{array}{l}20.7 \% \\
23.0 \% \\
18.4 \% \\
17.2 \% \\
11.5 \%\end{array}$ & $\begin{array}{l}20.4 \% \\
15.6 \% \\
12.6 \% \\
7.2 \% \\
7.2 \%\end{array}$ & $\begin{array}{l}22.2 \% \\
14.4 \% \\
18.0 \% \\
9.6 \% \\
6.6 \%\end{array}$ \\
\hline $\begin{array}{l}\text { Psychiatric } \\
\text { disorders }\end{array}$ & $\begin{array}{l}\text { Depression } \\
\text { Insomnia }\end{array}$ & $\begin{array}{l}29.4 \% \\
22.4 \% \\
\end{array}$ & $\begin{array}{l}27.6 \% \\
21.8 \% \\
\end{array}$ & $\begin{array}{l}23.4 \% \\
16.2 \% \\
\end{array}$ & $\begin{array}{l}25.1 \% \\
21.6 \% \\
\end{array}$ \\
\hline $\begin{array}{l}\text { White cell \& res. } \\
\text { disorders }\end{array}$ & $\begin{array}{l}\text { Lymphopenia } \\
\text { Leucopenia } \\
\text { Granulocytopenia } \\
\text { Lymphadenopathy }\end{array}$ & $\begin{array}{l}22.4 \% \\
16.5 \% \\
9.4 \% \\
2.4 \%\end{array}$ & $\begin{array}{l}23.0 \% \\
14.9 \% \\
10.3 \% \\
14.9 \%\end{array}$ & $\begin{array}{l}19.8 \% \\
12.0 \% \\
7.8 \% \\
8.4 \%\end{array}$ & $\begin{array}{l}25.7 \% \\
13.8 \% \\
12.0 \% \\
10.2 \% \\
\end{array}$ \\
\hline $\begin{array}{l}\text { Liver \& biliary } \\
\text { system disorders }\end{array}$ & ALT increased & $11.8 \%$ & $14.9 \%$ & $13.8 \%$ & $12.6 \%$ \\
\hline $\begin{array}{l}\text { Urinary system } \\
\text { disorders }\end{array}$ & $\begin{array}{l}\text { Urinary tract } \\
\text { infection }\end{array}$ & $8.2 \%$ & $14.9 \%$ & $16.2 \%$ & $13.8 \%$ \\
\hline
\end{tabular}

Asymptomatic laboratory abnormalities were reported frequently with interferon dosing over the 4 years. Of the abnormalities noted, the cytopenias and abnormalities of liver function showed dose-related differences. Lymphopenia occurred in $35 \%$ of high-dose patients and $27 \%$ of low-dose patients. Thrombocylopenia was seen in $2.6 \%$ of patients on low-dose, and $8.2 \%$ of patients on high dose. Differences in the frequency of abnormal liver enzymes were seen which included elevated ALT (24\% for low dose vs. $30 \%$ for high dose, $p=0.07$ ) and elevated AST (11\% vs. $20 \%$, $p=0.03$ ). Severe elevations are uncommon and not ditferent between dose groups. These data suggest that there is only minimal evidence of significant dose-dependent lab abnormalities with interteron therapy in MS patients. Atter 4 years of therapy, $23.7 \%$ of the low dose and $14.3 \%$ of the high-dose patients had developed persistent neutralising antibodies ( $0=0.024 .44 \mathrm{mcg}$ vs. $22 \mathrm{mcg}$ ), the vast majority of which (91\%) developed within 24 months. The lower incidence in the high dose group may be due to the phenomenon of high-zone tolerance. While continuing interferon treatment, $20.0 \%$ of low-dose Nab+ patients reverted, while $25.7 \%$ of high-dose Nab+ patients reverted. The neutralising antibodies were associated with reduced clinical efficacy during years 3 and 4 and reduced MRI efficacy over 4 years. The table below presents adverse events that were reported in at least $10 \%$ of the patients in any treatmen group of the SPECTRIMS study; the AES are listed by WHOART System Organ Class and preferred term (sorted by preferred term in order of frequency). The most trequently reported adverse event was injection site inflammation, which occurred in $67 \%$ of both treated groups compared $1016 \%$ for placebo. Lower frequencies of the closely associated but more symptomatic injection site reactions were reported in 3 to 4 times as many treated patients as placebo patients. Injection site necrosis was seen in $3.3 \%$ and $8.8 \%$ of patients in the $22 \mathrm{mcg}$ and $44 \mathrm{mcg}$ groups respectively. but almost always as a single event per patient. The rate of necrosis was $1 / 3800$ injections for high-dose and 1/9600 for low-dose therapy. Liver function abnormalities were also reported 3 to 4 times more commonly with active therapy. The haemalopoietic system was also affected, with increased reports of leucopenia, granulocylopenia and lymphopenia associated with active therapy and most prominently with the higher dose. These haematopoietic abnormalities are expected side-effects of interferon therapy. Increased reports of anaemia and thrombocytopenia were noted with Ireatment, but these events occurred in less than $10 \%$ of patients.

Adverse Events Experienced by Patients Enrolled in the SPECTRIMS Study

\begin{tabular}{|l|l|c|c|c|}
\hline Body System & \multicolumn{1}{|c|}{$\begin{array}{c}\text { Preferred } \\
\text { term }\end{array}$} & Placebo & $\begin{array}{c}\text { Rebif } \\
\text { weekly }\end{array}$ & $\begin{array}{c}\text { Rebif } 132 \text { mcg } \\
\text { weekly }\end{array}$ \\
\hline Application site & Injection site inflammation (a)(b) & $15.6 \%$ & $66.5 \%$ & $67.2 \%$ \\
disorders & Injection site reaction (a)(b)(c) & $7.8 \%$ & $21.1 \%$ & $31.9 \%$ \\
& Injection site pain & $18.0 \%$ & $17.2 \%$ & $22.5 \%$ \\
& Injection site bruising (a) & $16.1 \%$ & $8.1 \%$ & $9.8 \%$ \\
\hline Body as a whole- & Influenza-like symptoms & $52.2 \%$ & $50.7 \%$ & $49.5 \%$ \\
general disorders & Headache (c) & $56.6 \%$ & $52.2 \%$ & $63.2 \%$ \\
& Fatigue (b)(c) & $32.2 \%$ & $33.0 \%$ & $43.1 \%$ \\
& Fever (c) & $11.7 \%$ & $14.4 \%$ & $19.1 \%$ \\
& Leg pain & $9.3 \%$ & $11.5 \%$ & $12.3 \%$ \\
& Asthenia (c) & $9.8 \%$ & $5.7 \%$ & $12.3 \%$ \\
\hline Centr. \& periph. & Hypertonia & $26.8 \%$ & $24.4 \%$ & $30.4 \%$ \\
nervous system & Diziness & $18 \%$ & $16.3 \%$ & $17.2 \%$ \\
disorders & Paraesthesia & $13.2 \%$ & $8.1 \%$ & $9.3 \%$ \\
& Hypoaesthesia & $9.3 \%$ & $10.0 \%$ & $8.3 \%$ \\
\hline Respiratory & Rhinitis & $41.5 \%$ & $38.3 \%$ & $33.3 \%$ \\
system disorders & Upper Resp Tract Infection & $33.2 \%$ & $31.1 \%$ & $26.0 \%$ \\
& Pharyngitis & $20.0 \%$ & $19.6 \%$ & $17.2 \%$ \\
\hline
\end{tabular}

\begin{tabular}{|l|l|c|c|c|}
\hline Gastro-intestinal & Nausea (b) & $26.3 \%$ & $23.9 \%$ & $17.6 \%$ \\
system disorders & Abdominal pain & $18.0 \%$ & $14.8 \%$ & $15.2 \%$ \\
& Diarrsoea & $15.6 \%$ & $18.7 \%$ & $13.7 \%$ \\
& Constipation & $19.0 \%$ & $14.8 \%$ & $13.2 \%$ \\
\hline Musculo-skeletal & Myalgia & $23.9 \%$ & $24.9 \%$ & $27.9 \%$ \\
system disorders & Arthral gia & $25.4 \%$ & $24.4 \%$ & $23.0 \%$ \\
& Back ain & $22.4 \%$ & $21.5 \%$ & $22.1 \%$ \\
& Muscle weakness & $18.0 \%$ & $17.2 \%$ & $16.7 \%$ \\
\hline Psychiatric & Depression & $28.8 \%$ & $32.1 \%$ & $34.8 \%$ \\
disorders & Insomnia & $22.0 \%$ & $20.6 \%$ & $23.5 \%$ \\
\hline White cell \& res. & Lymphopenia (b) & $15.1 \%$ & $21.5 \%$ & $26.0 \%$ \\
disorders & Geucopenia (a)(b)(c) & $4.9 \%$ & $11.0 \%$ & $21.1 \%$ \\
& Granulocytopenia (a)(b) & $2.0 \%$ & $9.1 \%$ & $13.2 \%$ \\
\hline Liver \& biliary & ALI increased (a)(b) & $7.3 \%$ & $21.1 \%$ & $23.0 \%$ \\
system disorders & AST increased (a)(b) & $3.4 \%$ & $11.5 \%$ & $13.2 \%$ \\
\hline Urinary system & Urinary tract infection & $26.3 \%$ & $34.4 \%$ & $27.0 \%$ \\
disorders & Cystitis & $12.7 \%$ & $17.2 \%$ & $10.8 \%$ \\
\hline Vision disorders & Vision abnormal (a)(b) & $11.7 \%$ & $10.5 \%$ & $4.9 \%$ \\
\hline Secondary terms & Traumas Nos & $28.3 \%$ & $24.9 \%$ & $23.0 \%$ \\
\hline
\end{tabular}

(a) Significant ditterence between placebo and Rebis 66 mcg weekly groups ( $p=0.05$ )

(b) Significant difference between placebo and Rebif" $132 \mathrm{mcg}$ weekly groups ( $p=0.05$ )

(c) Significant difference between Rebif* $66 \mathrm{mcg}$ and Rebif* $132 \mathrm{mcg}$ weekly groups ( $\mathrm{p}=0.05$ )

The data indicate that Rebif" is sate when administered chronically even at high dose. Furthermore. studies with Rebif* have included patients with disability ranging from none to severe, age ranging from 18 to 55 at study start and in the forms of MS (SPMS. RRMS) that comprise over $80 \%$ of all MS patients. In the ETOMS study adverse events were reported more frequently in patients assigned Rebir" than in those assigned placebo These events included iniection-site intlammation $(60 \%$ vs. $12 \%$ ), fever $(28 \%$ vs. $12 \%)$. myalgia $(17 \%$ vs. $9 \%$ ) and chills $(11 \%$ vs. $5 \%$ ). Serious adverse events were reported in five patients in the placebo group and six in the Interferon bela-1a group

\section{DOSAGE ANO ADMINISTRATION:}

Relapsing Forms of Multiple Sclerosis: Before initating a patient on Rebit" therapy, please review completely the CONTRAINOICATIONS section of this Product Monograph. The recommended dose is 44 mcg given 3 times per week by subcutaneous injection. The dose can be reduced $1022 \mathrm{mcg}$ tiw if the patient is not able to tolerate the higher dose. Treatment should be initiated under supervision of a physician experienced in the treatment of the disease. When first starting treatment with Rebif? in order 10 allow tachyphylaxis to develop thus reducing adverse events, it is recommended that $20 \%$ of the total dose be administered during the initial 2 weeks of therapy. $50 \%$ of total dose be administered in weeks 3 and 4 , and the full dose from the fitth week onwards. Please also review the WARNINGS and PRECAUTIONS sections and ensure appropriate monitoring of patients with depression, hepatic dystunction, a history of seizures, cardiac disease, renal dystunction, thyroid dystunction. myelosuppression, and female patients of childbearing potential. Patients should be advised of Rebif"'s side-effects and instructed on the use of aseptic technique when administering Rebits. The Rebits Patient Leaflet should be carefully reviewed with all patients, and patients should be educated on seff-care and advised to keep the Leaflet for continued reference during Rebis"s therapy. At the present time, it is not known for how long patients should be treated. Satery and efficacy with Rebif" have been demonstrated following 4 years of treatment. Theretore, it is recommended that patients should be evaluated atter 4 years of treatment with Rebif" and a decision for longer-term treatment be made on an individual basis by the treating physician.

Preparation of Solution: Liquid formulation: The liquid formulation in a pre-filled syringe is ready for use. These syringes are graduated to facilitate therapy initiation. The pre-filled syringes contain $22 \mathrm{mcg}$ and $44 \mathrm{mcg}$ of Rebi* respectively. The pre-filled syringes are ready for subcutaneous use only.

STABILITY AND STORAGE RECOMMENOATIONS: Liquid formulation: Reter to the date indicated on the labels for the expiry date. Rebif" liquid in a pre-filled syringe should be stored at $2-8^{\circ} \mathrm{C}$. Rebir" syringes may be stored for a limited period at room temperature (up to $25^{\circ} \mathrm{C}$ ). but not more than 1 month. Do not treeze.

\section{AVAILABILITY OF DOSAGE FORM:}

Rebits is available as a liquid formulation, in pre-filled syringes. Two package strengths are available: $22 \mathrm{mcg} / 0.5 \mathrm{~mL}$ and $44 \mathrm{mcg} / 0.5 \mathrm{~mL}$. The pre-filled syringes are supplied as single units, 3-packs and 12-packs. The pre-filled syringes are ready for subcutaneous use only.

The route of administration for Relapsing forms of Multiple Sclerosis is subcutaneous.

The Product Monograph is available upon request.

Serono Canada Inc.. Oakville, Ontario, Canada L6M 2G2

@ Trademark @ 2004

It you have any questions, call:

The Multiple Support Program at 1-888-MS-REBIF" (1-888-677-3243)

Reterences:

1. Rebit" product monograph. Serono Canada. November 2003

2. The PRISMS Study Group and University of British Columbia MS/MRI Analysis Group.

PRISMS 4: Iong-term efficacy of interteron-beta-1a in relapsing MS. Neurology 2001; 56: 1628-1636. 
$F^{\mathrm{I} I}$

$\underset{\text { sumatalptan succinate }}{\text { M I T R }} \boldsymbol{I}$

25mg, 50mg and $100 \mathrm{mg}$ Tablet

IMITREX

(sumatriptan succinate)

$6 \mathrm{mg}$ Subcutaneous Injection and Autoinjector

IMITREX

(sumatriptan)

$5 \mathrm{mg}$ and $20 \mathrm{mg}$ Nasal Spray

THERAPEUTIC CLASSIFICATION

PHARMACOLOGIC CLASSIFICATION

\section{Pharmacokinetics}

Pharmacokinetic parameters following subcutaneous, oral or intranasal administration are shown in Table 1 . Sumatriptan is rapidly absorbed after oral, subcutaneous and intranasal administration. The low oral and intranasal
bioavailability is primarily due to metabolism (hepatic and presystemic) and bioavailability is primarily due to metabolism (hepatic and presystemic) and partly due to incomplete absorption. The oral absorption of sumatriptan is no
significantly affected either during migraine attacks or by food. Inter-patient and intra-patient variability was noted in most pharmacokinetic parameters assessed.

Table 1: Summary of Pharmacokinetic Parameters

\begin{tabular}{|c|c|c|c|}
\hline Parameter & Subcutaneous & Oral & Intranasal \\
\hline Bioavailability & $96 \%$ & $14 \%$ & $16 \%$ \\
\hline $\mathrm{C}_{\max }(\mathrm{ng} / \mathrm{mL})$ & $6 \mathrm{mg}: 72 \mathrm{ng} / \mathrm{mL}$ & $\begin{array}{l}\text { 100mg: } 50-60 \mathrm{ng} / \mathrm{mL} \\
\text { 25mg: } 18 \mathrm{ng} / \mathrm{mL}\end{array}$ & $\begin{array}{l}5 \mathrm{mg}: 4.7 \mathrm{ng} / \mathrm{mL} \\
10 \mathrm{mg}: 8.5 \mathrm{ng} / \mathrm{mL} \\
20 \mathrm{mg}: 14.4 \mathrm{ng} / \mathrm{mL}\end{array}$ \\
\hline $\mathrm{T}_{\max }$ & $6 \mathrm{mg}: 15 \mathrm{~min}$ & $100 \mathrm{mg}: 0.5-5 \mathrm{hr}^{*}$ & $1-1.5 \mathrm{hr}$ \\
\hline $\mathrm{T}_{12}$ & $2 \mathrm{hr}(1.7-2.3 \mathrm{hr})$ & $2 \mathrm{hr}(1.9-2.2 \mathrm{hr})$ & $2 \mathrm{hr}(1.3-5.4 \mathrm{hr})$ \\
\hline Protein Binding & \multicolumn{3}{|c|}{$14-21 \%$} \\
\hline Volume of Distribution & \multicolumn{3}{|c|}{$170 \mathrm{~L}$} \\
\hline $\begin{array}{l}\text { Total Plasma } \\
\text { Clearance }\end{array}$ & \multicolumn{3}{|c|}{$1160 \mathrm{~mL} / \mathrm{min}$} \\
\hline $\begin{array}{l}\text { Renal Plasma } \\
\text { Clearance }\end{array}$ & \multicolumn{3}{|c|}{$260 \mathrm{~mL} / \min$} \\
\hline
\end{tabular}

In vitro studies with human microsomes suggest that sumatriptan is metabolized by monoamine oxidase (MAO), predominantly the $A$ isoenzyme. In studies clearance, significantly increasing systemic exposure.

Non-renal clearance of sumatriptan accounts for about $80 \%$ of the total clearance. The major metabolite, the indole acetic acid analogue of sumatriptan is mainly excreted in the urine where it is present as a free acid $(35 \%)$ and the metabolites have not been identified.

No differences have been observed between the pharmacokinetic parameters in healthy elderly volunteers compared with younger volunteers (less than 65 years old). 15 minutes following intranasal administration and 30 minutes following oral administration.

INDICATIONS AND CLINICAL USES

IMITREX DF'M (sumatriptan succinate) and IMITREX (sumatriptan with or without aura.

IMITREX DFTM and IMITREX ${ }^{\circledR}$ is not for use in the management of hemiplegic basilar, or ophthalmoplegic migraine (see CONTRAINDICATIONS). Satety and efficacy have nol been eslabish lor CONTRAINDICATIONS

IMITREX DF'M (sumatriptan succinate) and IMITREX (sumatriptan succinate/sumatriptan) is contraindicated in patients with history, symptoms, or signs of ischemic cardiac, cerebrovascular, or peripheral vascular syndromes, valvular heart disease or cardiac arrhythmias (especially tachycardias). In addition, patients with other significant underlying cardiovascular diseases (e.g., atherosclerotic disease, congenital heart disease) should not receive IMITREX DFTM and IMITREX ${ }^{\bullet}$. Ischemic cardiac syndromes include, but are not limited to, angina pectoris of any type (e.g., stable
angina of effort and vasospastic forms of angina such as the angina of effort and vasospastic forms of angina such as the
Prinzmetal's variant), all forms of myocardial infarction, and silent Prinzmetal's variant), all forms of myocardial infarction, and silent
myocardial ischemia. Cerebrovascular syndromes include, but are myocardial ischemia. Cerebrovascular syndromes include, but are
not limited to, strokes of any type as well as transient ischemic not limited to, strokes of any type as well as transient ischemic
attacks (TIAs). Peripheral vascular disease includes, but is not attacks (TIAs). Peripheral vascular disease includes, but is not
limited to, ischemic bowel disease, or Raynaud's syndrome (see WARNINGS

Because IMITREX DFrm and IMITREX may increase blood pressure, it is contraindicated in patients with uncontrolled or severe hypertension.

Concurrent administration of MAO inhibitors or use within 2 weeks of discontinuation of MAO inhibitor therapy is contraindicated (see Ergot-containing drugs have been reported to cause prolonged vasospastic reactions. Because IMITREX DFTM and IMITREX may also cause coronary vasospasm and these effects may be additive,
the use of IMITREX DFrM and IMITREX the use of IMITREX DFrM and IMITREX within 24 hours before or
after treatment with other $5-\mathrm{HT}_{1}$ receptor agonists, or ergotamineafter treatment with other $5-\mathrm{HI}_{1}$ receptor agonists, or ergotamine-
containing drugs or their derivatives (eg. dihydroergotamine, containing drugs or their derivativ
methysergide) is contraindicated.

methysergide) is contraindicated.
IMITREX DFM and IMITREX should not be administered to patients with severe hepatic impairment.

IMITREX DF'M and IMITREX is contraindicated in patients with hemiplegic, basilar, or ophthalmoplegic migraine

IMITREX DF'M and IMITREX is contraindicated in patients with formulations. potential to cause coronary vasospasm.
WARNINGS succinate/sumatriptan) should only be used where a clear diagnosis of succinate/sumatriptan) should
migraine has been established. Risk of Myocardial Ischemia and/or Infarction and Other Adverse Cardiac Events: IMITREX DF'M and IMITREX ${ }^{\circledR}$ has been associated with transien chest and/or neck pain and tightness which may resemble angina pectoris. In rare cases, the symptoms have been identified as being the likely result of coronary vasospasm or myocardial ischemia. Rare cases of serious coronary events or arrhythmia have occurred following use of IMITREX DF'M
and IMITREX and IMITREX
patients who have documented ischemic or vasospastic coronary artery disease (CAD) (see CONTRAINDICATIONS). It is strongly recommende that IMITREX DFrm and IMITREX not be given to patients in whom unrecognized CAD is predicted by the presence of risk factors (e.g. hypertension, hypercholesterolemia, smoking, obesity, diabetes, strong
family history of CAD, female who is surgically or physiologically tamily history of CAD, female who is surgically or physiologically postmenopausal, or male who is over 40 years of age) unless a cardiovascular evaluation provides satisfactory clinical evidence that the patient is reasonably free of coronary artery and ischemic myocardial disease or
other significant underlying cardiovascular disease. The sensitivity of other significant underlying cardiovascular disease. The sensitivity of cardiac diagnostic procedures to detect cardiovascular disease or predisposition to coronary artery vasospasm is unknown. If, during the cardio-
vascular evaluation, the patient's medical history or electrocardiographic investigations reveal findings indicative of, or consistent with, coronary
artery vasospasm or myocardial ischemia. IMITREX DF'M and IMITREX artery vasospasm or myocardial ischemia, IMITREX DF
should not be administered (see CONTRAINDICATIONS).

For patients with risk factors predictive of CAD, who are considered to have a satisfactory cardiovascular evaluation, the first dose of
IMITREX DF'M and IMITREX should be administered in the setting of a hysician's office or similar medically staffed and equipped facility. Because cardiac ischemia can occur in the absence of clinical symptoms consideration should be given to obtaining electrocardiograms in patients with risk factors during the interval immediately following IMITREX DF'M and IMITREX administration on the first occasion of use. However, an absence of drug-induced cardiovascular effects on the occasion of the initial dose does not preclude the possibility of such effects occurring with subsequent administrations. Intermittent long term users of IMITREX DFrm and IMITREX who have or acquire risk factors predictive of CAD, as described above, should receive periodic interval cardiovascular evaluations over the course of treatment. If symptoms consistent with should be carried out to look for ischemic changes.

The systematic approach described above is intended to reduce the likelihood that patients with unrecognized cardiovascular disease will be
inadvertently exposed to IMITREX DF'M and IMITREX.

Cardiac Events and Fatalities Associated with 5-HT, Agonists: IMITREX DF ${ }^{\mathrm{M}}$ and IMITREX ${ }^{8}$ can cause coronary artery vasospasm. Serious adverse cardiac events, including acute myocardial infarction, life threatening disturbances of tration of $5-\mathrm{HT}$, and deants have been reported within a few hours tollowing the adminiswith migraine, the incidence of these events is extremely low. The fact that some of these events have occurred in patients with no prior cardiac disease history and with
documented absence of CAD and the close proximity of the events to IMITREX DFT and IMITREX $X^{8}$ use support the conclusion that some of these cases were caused by the drug. In many cases, however, where there has been known underlying coronary artery disease, the relationship is uncertain.

Premarketing Experience With IMITREX DFTM and IMITREX Of 6348 patients with migraine who participated in premarketing controlled and uncontrolled clinical trials of oral IMITREX DFT' and IMITREX' , wo experienced clinical adverse events shortly after receiving oral IMITREX DF'M and IMITREX that may have serious clinimary ousospas Among the more than 1900 patients with migraine who participated in premarketing
controlled clinical trials of subcutaneous IMITREX DF patients who sustained clinical events during or shortly after receiving
IMITREX DF $F^{\mathbb{M}}$ and IMITREX that may have reflected coronary artery vasospasm. Six of these eight patients had ECG changes consistent with transient ischemia, but without accompanying clinical symptoms or signs. Of these eight patients, four had either findings suggestive of CAD or risk factors predictive of CAD prior to study enrollment. Among approximately 4,000 patients with migraine who participated in premarketing controlled and uncontrolled clinical trials of IMITREX nasal spray, one patient experienced an asymptomalic

Postmarketing Experience With IMITREX DF'M and IMITREX * Serious cardiovascular events, some resulting in death, have been reported in association with uncontrolled nature of postmarketing surver determine definitively the proportion of the reported cases that were actually caused by MITREX DF ${ }^{M}$ and IMITREX or to reliably assess causation in individual cases. On clinical grounds, the longer the latency between the administration of $1 M I T R E X D F M$ and causative. Accordingly interest has focused on events beginning within 1 hour of the administration of IMIITREX DF'M and IMITREX

政 and IMITREX ${ }^{3}$ administration include: coronary artery vasospasm, transient ischemia, myocardial infarction, ventricular tachycardia and ventricular fibrillation, cardiac arrest, and death

Some of these events occurred in patients who had no findings of CAD and appear to represent consequences of coronary artery vasospasm. However, among reports from the USA of serious cardiac events occurring within 1 hour of IMITREX DFTM and
IMITREX administration, almost all of the patients had risk tactors predictive of CAD and the presence of significant underlying CAD was established in most cases (see CONTRAINDICATIONS)

Cerebrovascular Events and Fatalities with 5-HT, Agonists: Cerebral hemorrhage, subarachnoid hemorrhage, stroke, and other cerebrovascular events have been reported in patients treated with oral or subcutaneous IMITREX DF'T and
IMITREX and some have resulted in fatalities. The relationship of IMITREX DFIM and MITREX ${ }^{8}$ to these events is uncertain. In a number of cases, it appears possible that the cerebrovascular events were primary. IMITREX DFFM and IMITREX having been administered in the incorrect belief that the symptoms experienced were a consequence of migraine when they were not. IMITREX DFTM and IMITREX
administered if the headache being experienced is atypical for the patient. It should be be noted that patients with migraine may be at increased risk of certain cerebrovascular events (e.g. stroke, hemorrhage, TIA). If a patient does not respond to the first dose, the opportunity should be taken to review the diagnosis before a second dose is given.
Special Cardiovascular Pharmacology Studies: In subjects $(n=10)$ with suspected coronary artery disease undergoing angiography, a $5-\mathrm{HT}_{1}$ agonist at a subcutaneous dose of $1.5 \mathrm{mng}$ produced an $8 \%$ increase in aortic blood pressure, an $18 \%$ increase in pulmonary artery blood pressure, and an $8 \%$ increase in systemic
vascular resistance. In addition, mild chest pain or tightness was reported by four vascular resistance. In addition, mild chest pain or tightness was reported by four
subjects. Clinically significant increases in blood pressure were experienced by three of the subjects (two of whom also had chest pain/discomfort). Diagnostic angiogram
results revealed that 9 subjects had normal coronary arteries and 1 had insignificant coronary artery disease.

In an additional study with this same drug, migraine patients $(n=35)$ free of cardio-
. vascular disease were subjected to assessments of myocardial pertusion by positron migraine attack Reduced coronary vasodilatory reserve $(\sim 10 \%)$, increase in coronary resistance $(-20 \%)$, and decrease in hyperemic myocardial blood flow $(-10 \%)$ were noted. The relevance of these finding to the use of the recommended oral doses of this

Similar studies have not been done with IMITREX DFTM and IMITREX. However, owing to the common pharmacodynamic actions of 5-HT, agonists, the possibility of cardio-
vascular effects of the nature described above should be considered for any agent of this pharmacological class

Hypersensitivity: Rare hypersensitivity (anaphylaxis/anaphylactoid) reactions may
occur in patients receivino 5 -HT, agonists such as IMITREX DFT'T and IMITREX Such occur in patients receiving 5-HT, agonists such as IMITREX DF ${ }^{\text {TM and IMITREX }}$. Such reactions can be life threatening or tatal. In general, hypersensitivity reactions to drugs
are more likely to occur in individuals with a history of sensitivity to multiple allergens (see CONIRANDICATIONS). Owing to the possibility of cross-reactive hypersensitivity reactions, IMITREX DFTM and IMITREX ${ }^{*}$ should not be used in patients having a history
of hypersensitivity to chemically-related 5 -HT, receptor agonists. There have been reports of patients with known hypersensitivity to sulphonamides exhibiting an allergic reaction following administration of IMITREX DF'M and IMITREX'. Reactions ranged from cutaneous hypersensitivity to anaphylaxis.
Other Vasospasm Related Events: 5

Other Vasospasm Related Events: $5-\mathrm{HT}_{1}$ agonists may cause vasospastic reactions other than coronary artery vasospasm. Extensive post-market experience has
shown the use of IMITREX DFFM and IMITREX to be associated with rare occurrences of peripheral vascular ischemia and colonic ischemia with abdominal pain and bloody diarrhen

Increase in Blood Pressure: Significant elevation in blood pressure, including hypertensive crisis, has been reported on rare occasions in patients with and without a history of hypertension. IMITREX DFTM and IMITREX is contraindicated in patients with uncontrolled or severe hypertension (see CONTRAINDICATIONS). In patients with
controlled hypertension, IMITREX DF" and IMITREX caution, as transient increases in blood pressure and peripheral vascular resistance have been observed in a small portion of patients.

Cluster Headache: There is insufficient information on the efficacy and safety of
IMITREX DFM (sumatriptan succinate) and IMITREX (sumatriptan succinate/sumatriptan) in the treatment of cluster headache, which is present in an older, predominantly male population. The need for prolonged use and the demand for cluster headache.

Cardiovascular: Discomfort in the chest, neck, throat and jaw (including pain, pressure, heaviness and tightness) has been reported after adminiscoronary artery vasospasm, patients who experience signs or symptoms evaluated for the presence of $C A D$ or a predisposition to variant angina before receiving additional doses, and should be monitored electrocardiographically if dosing is resumed and similar symptoms recur. Similarly, patients who experience other symptoms or signs suggestive of decreased arterial flow, such as ischemic bowel syndrome or Raynaud's syndrome following IMITREX DFTM and IMITREX should be evaluated for atheroWARNINGS)

Neurological Conditions: Care should be taken to exclude other potentially serious neurologic conditions before treating headache in patients not previously diagnosed with migraine headache or who experience a headache that is atypical for them. There were subsequently shown to have been secondary to an evolving neurologic lesion. For newly diagnosed patients or patients presenting with atypical symptorms, the diagnosis of migraine sho

Seizures: Caution should be observed if IMITREX DFTM and IMITREX ${ }^{\circ}$ is to be used in patients with a history of epilepsy or structural brain lesions which lower the convulsion threshold

Psychomotor Impairment: Patients should be cautioned that drowsiness may occur as a result of treatment with IMITREX DF'M and IMITREX . They should be advised no to pertorm skilled tasks (e.g. driving or operating machinery) if drowsiness occurs. IMITREX DFM and IMITREX
I have not been evaluated. Therefore IMITREX DFFM and IMITREX is not recommended in this patient population

Hepatic impairment: the efleci of hepatic impairment on the efficacy and safely of IMITREX DFM and IMITREX ${ }^{8}$ has not been evaluated, however, the pharmacokinetic profile of sumatriptan in patients with moderate' hepatic impairment shows that these patients, following an oral dose of $50 \mathrm{mg}$, have much higher plasma sumatriptan
concentrations than healthy subjects (Table 2). Therefore, an oral dose of $25 \mathrm{mg}$ may be considered in patients with hepatic impairmen.

Table 2: Pharmacokinetic Parameters After Oral Administration

of IMITREX 50 Hepatically Impaired Patients

\begin{tabular}{|c|c|c|c|}
\hline Parameter & $\begin{array}{c}\text { Mean Ratio } \\
\text { (hepatic impaired/healthy) } \\
n=8\end{array}$ & $\mathbf{9 0 \% ~ C l}$ & p-value \\
\hline AUC $_{\infty}$ & $181 \%$ & 130 to $252 \%$ & $0.009^{*}$ \\
$\mathrm{C}_{\max }$ & $176 \%$ & 129 to $240 \%$ & $0.007^{*}$ \\
\hline
\end{tabular}

The pharmacokinetic parameters of $6 \mathrm{mg}$ subcutaneous sumatriptan do not differ statistically between normal volunteers and moderately hepatically impaired subjects. However, sumatriptan should not be admin
severe hepatic impairment (see CONTRAINDICATIONS)

Drug Interactions: Single dose pharmacokinetic drug interaction studies have not shown evidence of interactions with propranolol, flunarizine, pizotifen or alcohol. Multiple dose interaction studies have not been performed. The pharmacokinetics of sumatriptan nasal spray were unaltered when preceded by Trademark Ciba Self Medication

Ergot-Containing Drugs: Ergot-containing drugs have been reported to cause prolonged vasospastic reactions. Because there is a theoretical basis for these dihydroergotamine or methysergide) are contraindicated within 24 hours of MAO Inhibitors: In studies conducted in a limited number of patients, MAO inhibitors reduce sumatriptan clearance, significantly increasing systemic exposure. Therefore, the use of IMITREX DFTM and IMITREX in patients
receiving MAO inhibitors is contraindicated (see CONTRAINDICATIONS, AND

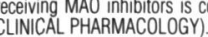

Other Serotonergic Drugs: Rare postmarketing reports describe patients with weakness, hyperreflexia, and incoordination following the combined use of a treatment with IMITREX DFTM/ IMITREX and an SSRI (e.g. fluoxetine, serotonergic activity is clinically warranted, appropriate observation of the patient for acute and long-term adverse events is advised. 
Other 5-HT, agonists: The administration of IMITREX DF'M and IMITREX with other 5-HT, agonists has not been evaluated in migraine patients. As an increased risk of agonists, use of these drugs within 24 hours of each other is contraindicated.

Drug/Laboratory Test Interactions: IMITREX DFTM and IMITREX are not known to intertere with commonly employed clinical laboratory tests

Use in Elderly (>65 years): Experience of the use of IMITREX DFTM and IMITREX in patients aged over 65 years is limited Therotore the use of IMITREX DFTM and IMITREX $X^{s}$ in patients over 65 years is not recommended.

Use in Children ( $<18$ years): The satety and efficacy of IMITREX DFTM and IMITREX ${ }^{B}$ in children has not been established and its use in this age group is not

Use in Pregnancy: Reproduction studies, pertormed in rats, have not revealed any evidence of impaired fertility, teratogenicity. of post-natal development due to IMITREX DF TM and IMITREX ${ }^{3}$. Reproduction studies, performed in rabbits by the oral route, have shown increased incidence of variations in cervico-thoracic blood vesse configuration in the foetuses. These effects were only seen at the highest dose tested which affected weight gain in the dams, and at which blood levels were in excess of 50 times those seen in humans atter therapeutic doses. A direct association with

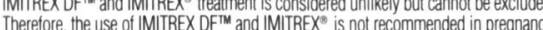
in a rat tertility study, oral doses of IMITREX DF'M and IMITREX levels approximately, 150 times those seen in humans after a $6 \mathrm{mg}$ subcutaneous dose levels approximately 150 times those seen in humans atter a $6 \mathrm{mg}$ subcutaneous dose
and approximately 200 times those seen in humans atter a $100 \mathrm{mg}$ oral dose were associated with a reduction in the success of insemination. This effect did not occur associated with a reduction in the success of insemination. This effect did not occur
during a subcutaneous study where maximum plasma levels achieved approximately during a subcutaneous study where maximum plasma levels achieved approximately
100 times those in humans by the subcutaneous route and approximately 150 times those in humans by the oral route.

To monitor maternal-foetal outcomes of pregnant women exposed to sumatriptan, a Pregnancy Registry has been established. Physicians are encouraged to register patients by calling 1-800-336-2176.

Lactation: Sumatriptan is excreted in human breast milk. Therefore, caution is advised

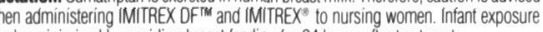
(1) Melanin goreast teeding for 24 hours after treatment

政 subcutaneous dose $(0.5 \mathrm{mg} / \mathrm{kg})$ or oral dose $(2 \mathrm{mg} / \mathrm{kg})$ of radiolabeled sumatriptan, the elimination half life of radioactivity from the eye was 15 and 23 days the eye Because there could be an accumulation in melanin rich tissues over time ths the eye. Beccossibility that sumatriptan could cause toxicity in these tissues a raises the possibility that sumatriptan could cause toxicity in these tissues atte extended use. However, no effects on the retina related to treatment with sumatriptan were noted in any of the oral or subcutaneous toxicity studies. Although no systematic
monitoring of ophthalmologic tunction was undertaken in clinical trials and no specific recommendations for ophthalmologic monitoring are offered, prescribers should be recommendations for ophthalmologic monitoring are offered,
aware of the possibility of long term ophthalmologic effects.

Laboratory Tests: No specific laboratory tests are recommended for monitoring ADVERSE REACTIONS

Serious cardiac events, including some that have been fatal, have occurred following the use of 5-HT 1 agonists. These events are extremely rare and most have been reported in patients with risk factors predictive of CAD. Events reported have included coronary artery vasospasm, tachycardia, and ventricular fibrillation (see CONTRAINDICATIONS,
WARNINGS, and PRECAUTIONS).

Experience in Controlled Clinical Trials with IMITREX DF'M and IMITREX Typical 5-HT, Agonist Adverse Reactions: As with other $5-\mathrm{HT}_{1}$ agonists, IMITREX DFM (sumatriptan succinate) and IMITREX ${ }^{8}$ (sumatriptan succinate/sumatriptan) has been associated with sensations of heaviness, pressure, tightness or pain which may be intense. These may occur in any part of the body including the chest, throat, neck, jaw and upper limb.

Acute Salety: In placebo-controlled migraine trials, 7,668 patients received at least 3141 intranasal). The following tables (Tables 3-5) list adverse events occurring in dose groups and that occurred at a higher incidence than in the placebo groups.

Table 3: Treatment-Emergent Adverse Events in Oral PlaceboControlled Clinical Trials Reported by at Least $1 \%$ of Patients with Migraine

\begin{tabular}{|c|c|c|c|c|}
\hline & \multirow[t]{2}{*}{ Placebo } & \multirow{2}{*}{$\begin{array}{c}\text { IMITREX } \\
25 \mathrm{mg}\end{array}$} & \multicolumn{2}{|c|}{ IMITREX ${ }^{8}$ IMITREX } \\
\hline & & & $50 \mathrm{mg}$ & $100 \mathrm{mg}$ \\
\hline Number of Migraine Attacks Treated & 1187 & 945 & 1889 & 14750 \\
\hline \multicolumn{5}{|c|}{ Symptoms of Potentially Cardiac Origin } \\
\hline - Chest Sensations* & $0.6 \%$ & $2.3 \%$ & $2.6 \%$ & $3.2 \%$ \\
\hline - Neck/Throat/Jaw Sensations* & $1.4 \%$ & $2.3 \%$ & $3.5 \%$ & $52 \%$ \\
\hline - Upper Limb Sensations* & $1.2 \%$ & $1.4 \%$ & $2.5 \%$ & $3.6 \%$ \\
\hline - Palpitations & $0.6 \%$ & $0.3 \%$ & $1.0 \%$ & $1.1 \%$ \\
\hline \multicolumn{5}{|l|}{ Neurological } \\
\hline - HeadFace Sensations* & $1.3 \%$ & $2.3 \%$ & $2.5 \%$ & $4.7 \%$ \\
\hline - Dizziness & $2.5 \%$ & $3.1 \%$ & $3.3 \%$ & $6.2 \%$ \\
\hline - Headache & $3.3 \%$ & $4.0 \%$ & $2.2 \%$ & $3.3 \%$ \\
\hline - Vertigo & $0.6 \%$ & $1.1 \%$ & $1.1 \%$ & $1.0 \%$ \\
\hline - Drowsiness & $1.6 \%$ & $1.1 \%$ & $1.2 \%$ & $2.1 \%$ \\
\hline - Tremor & $0.4 \%$ & $0.9 \%$ & $0.4 \%$ & $1.1 \%$ \\
\hline \multicolumn{5}{|l|}{ Gastrointestinal } \\
\hline - Nausea & $5.8 \%$ & $2.8 \%$ & $4.4 \%$ & $11.0 \%$ \\
\hline - Hyposalivation & $1.2 \%$ & $1.4 \%$ & $1.1 \%$ & $1.2 \%$ \\
\hline • Vomiting & $2.9 \%$ & $4.3 \%$ & $1.1 \%$ & $4.4 \%$ \\
\hline - Gastrointestinal Discomfort \& Pain & $1.4 \%$ & $1.1 \%$ & $0.8 \%$ & $2.0 \%$ \\
\hline - Abdominal Discomtort \& Pain & $0.3 \%$ & NR & $0.4 \%$ & $1.2 \%$ \\
\hline • Diarnea & $0.9 \%$ & $0.3 \%$ & $0.6 \%$ & $1.1 \%$ \\
\hline \multicolumn{5}{|l|}{ Musculoskeletal } \\
\hline - Musculoskeletal Pain & $0.7 \%$ & $2.3 \%$ & $0.4 \%$ & $1.4 \%$ \\
\hline - Muscle Pain & $0.3 \%$ & $0.9 \%$ & $0.1 \%$ & $1.0 \%$ \\
\hline - Muscle Atrophy Weakness \& Tirednes & SS NR & $0.6 \%$ & $0.4 \%$ & $1.4 \%$ \\
\hline \multicolumn{5}{|l|}{ Ear, Nose \& Throat } \\
\hline - Infections & $0.6 \%$ & $0.6 \%$ & $1.1 \%$ & $1.4 \%$ \\
\hline - Nasal Signs \& Symptoms & $0.7 \%$ & $1.4 \%$ & $0.8 \%$ & $1.0 \%$ \\
\hline - Throat \& Tonsil Symptoms & $0.6 \%$ & NR & $0.4 \%$ & $2.3 \%$ \\
\hline \multicolumn{5}{|l|}{ Respiratory } \\
\hline - Viral Infection & $0.3 \%$ & $1.1 \%$ & $0.1 \%$ & $1.0 \%$ \\
\hline \multicolumn{5}{|l|}{ Non-Site Specific } \\
\hline - Limb Sensations* & $0.4 \%$ & $1.1 \%$ & $0.4 \%$ & $1.5 \%$ \\
\hline - Sensations* (body region unspectified) & $4.5 \%$ & $5.7 \%$ & $8.0 \%$ & $9.0 \%$ \\
\hline - Malaise/Fatigue & $5.1 \%$ & $3.7 \%$ & $2.6 \%$ & $9.5 \%$ \\
\hline - Sweating & $0.4 \%$ & $0.6 \%$ & $0.6 \%$ & $1.6 \%$ \\
\hline
\end{tabular}

The term "sensations" encompasses adverse events described as pain \& discomfort, pressure,
leaviness, constriction, tightness, heat burning sensation, paresthesia, numbness, tingling, and travange ensations.
s.. Includes patients receiving up to 3 doses of $100 \mathrm{mig}$

$\ddot{N R}=$ Not Reported
Table 4: Treatment-Emergent Adverse Events in Subcutaneous Placebo-Controlled Clinical Trials Reported by at Least 1\% of Patients with Migraine

\begin{tabular}{|c|c|c|}
\hline & Placebo & IMIREX' $6 \mathrm{mg}$ \\
\hline Number of Patients & 615 & 1432 \\
\hline Number of Migraine Attacks Treated & 742 & 2540 \\
\hline \multicolumn{3}{|l|}{ Symptoms of Potentially Cardiac Origin } \\
\hline - Chest Sensations* & $1.6 \%$ & $5.7 \%$ \\
\hline - Neck/Throat/Jaw Sensations* & $1.3 \%$ & $12.0 \%$ \\
\hline - Upper Limb Sensations* & $2.0 \%$ & $6.8 \%$ \\
\hline \multicolumn{3}{|l|}{ Neurological } \\
\hline - Head/Face Sensations* & $3.7 \%$ & $16.6 \%$ \\
\hline - $\quad$ Dizziness & $3.7 \%$ & $7.9 \%$ \\
\hline - Headache & $0.7 \%$ & $3.4 \%$ \\
\hline - Drowsiness & $1.8 \%$ & $2.9 \%$ \\
\hline \multicolumn{3}{|l|}{ Gastrointestinal } \\
\hline - $\quad$ Nausea & $5.9 \%$ & $9.4 \%$ \\
\hline - Hyposalivation & $2.8 \%$ & $3.3 \%$ \\
\hline \multicolumn{3}{|l|}{ Musculoskeletal } \\
\hline - $\quad$ Muscle Atrophy Weakness \& Tiredness & NR & $1.7 \%$ \\
\hline \multicolumn{3}{|l|}{ Ear / Nose and Throat } \\
\hline - $\quad$ Throat \& Tonsil Symptoms & $0.3 \%$ & $1.0 \%$ \\
\hline \multicolumn{3}{|l|}{ Respiratory } \\
\hline - Breathing Disorders & $0.8 \%$ & $1.3 \%$ \\
\hline \multicolumn{3}{|l|}{ Non-Site Specific } \\
\hline - $\quad$ Sensations* (body region unspecified) & $15.9 \%$ & $39.0 \%$ \\
\hline - Injection Site Reactions & $10.4 \%$ & $24.7 \%$ \\
\hline - $\quad$ Limb Sensations* & $1.5 \%$ & $6.0 \%$ \\
\hline - Malaise/Fatigue & $2.3 \%$ & $4.7 \%$ \\
\hline - $\quad$ Sweating & $1.1 \%$ & $1.7 \%$ \\
\hline - Trunk Symptoms* & $0.5 \%$ & $1.4 \%$ \\
\hline
\end{tabular}

"The term "sensations" encompasses adverse events described as pain \& discomtort, pressure,
heaviness, constriction, tightness, heatburning sensation, paresthesia, numbers, ting ling, and strange sensations.

Table 5: Treatment-Emergent Adverse Events in Intranasal PlaceboControlled Clinical Trials Reported by at Least $1 \%$ of Patients with Migraine

\begin{tabular}{|c|c|c|c|c|}
\hline & Placebo & IMITREX & IMITREX & IMITREX \\
\hline & & $5 \mathrm{mg}$ & $10 \mathrm{mg}$ & $20 \mathrm{mg}^{* *}$ \\
\hline Number of Patients & 741 & 496 & 1007 & 1638 \\
\hline
\end{tabular}

\begin{tabular}{|lllll|}
\hline $\begin{array}{l}\text { Number of Migraine } \\
\text { Attacks Treated }\end{array}$ & 1047 & 933 & 1434 & 2070 \\
\hline
\end{tabular}

\section{Symptoms of Potentially}

Cardiac Origin

- Chest Sensations*

$0.3 \% \quad 1.0 \% \quad 0.7 \% \quad 0.6 \%$

- Neck/Throat/_aw

- Head/Face Sensations*

\begin{tabular}{llll}
$1.2 \%$ & $0.6 \%$ & $1.6 \%$ & $2.3 \%$ \\
\hline
\end{tabular}

- Dizziness

$\begin{array}{ll}0.8 \% & 1.4 \% \\ 12 \% & 1.6 \%\end{array}$

- Headache

\begin{tabular}{llll}
$0.7 \%$ & $1.4 \%$ & $0.5 \%$ & $1.2 \%$ \\
\hline & $-3.8 \%$ & $0.8 \%$
\end{tabular}

- Migraine

- Nausea

$2.6 \% \quad 3.2 \% \quad 2.4 \% \quad 1.8 \%$

- Vomiting

\begin{tabular}{llll}
$10.4 \%$ & $14.3 \%$ & $9.6 \%$ & $8.3 \%$ \\
\hline $7.6 \%$ & $11.1 \%$ & $9.6 \%$ & $6.8 \%$
\end{tabular}

\section{Ear, Nose \& Throat}

- Sensitivity to Noise

- Nasal Signs \& Symptoms

- Infections

- Upper Respiratory Inflammation

\section{Non-Site Specific}

- Sensations*

(body region unspecified)

- Malaise/Fatigue

- Descriptions of odor or taste

$3.1 \% \quad 4$.

$4 \% \quad 2.5 \% \quad 1.5 \%$

\begin{tabular}{llll}
$1.1 \%$ & $4.4 \%$ & $2.5 \%$ & $1.5 \%$ \\
\hline $3.0 \%$ & $1.6 \%$ & $1.8 \%$ \\
\hline & $1.8 \%$ & $1.3 \%$ & $0.5 \%$
\end{tabular}

\begin{tabular}{llll}
$9 \%$ & $1.8 \%$ & $1.3 \%$ & $0.5 \%$ \\
\hline & $1.0 \%$ & $0.6 \%$ & $0.7 \%$
\end{tabular}

"The term "sensations" encompasses adverse events described as pain \& discomtort, pressure. strange sensations.

Includes patients receiving up to 3 doses of $20 \mathrm{mg}$

IMITREX DFTM and IMITREX is generally well tolerated. Most of the events were transient in nature and resolved within 45 minutes of subcutaneous administration and within 2 hours of oral or intranasal administration

Of the 3630 patients treated with IMITREX ${ }^{\infty}$ Nasal Spray in clinical trials, there was one report of a coronary vasospasm related to IMITREX ${ }^{8}$ administration. sumatristarnances of liver function tests have occasional ly been observed with sumatriplan freatment. There is no evidence that clinically significant Patients treated with IMITREX DFTM and IMITREX rarely exhibit visual disorders like flickering and diplopia. Additionally cases of nystagmus vision has been reported. However, visual disorders may also occur during a migraine attack itsell.

\section{DOSAGE AND ADMINISTRATION} IMITREX DFTM (sumatriptan succinate) and IMITREX (sumatriptan
succinate/sumatriptan) is indicated for the acute treatment of used prophylactically. Sumatriptan may be given orally, subcutaused prophylactically. Sumatriptan may be given orally, subcuta-
neously or as a nasal spray. The safety of treating an average of more than four headaches in a 30 day period has not been established.

In selecting the appropriate formulation for individual patients, consideration should be given to the patient's preterence for tormulation and the patient's 10-15 minutes following subcutaneous injection, 15 minutes following intranasal administration and 30 minutes following oral administration. In addition to relieving the pain of migraine, sumatriptan (all formulations) has
also been shown to be effective in relieving associated symptoms of migraine (nausea, vomiting, phonophobia, photophobia). Sumatriptan is equally (nausea, vomiting, phonophobia, photophobia). Sumatriptan is equally (12-24 months) clinical studies with maximum recommended doses of
sumatriptan indicate that there is no evidence of the development of tachyphylaxis, or medication-induced (rebound) headache.
Tablets:

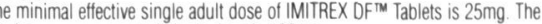
The optim recommended single dose is $100 \mathrm{~m}$

The optimal dose is a single 50mg tablet. However, depending on individual patient's needs and response to treatment, some patients may require $100 \mathrm{mg}$. headache relief within two hours after oral dosing with $100 \mathrm{mg}$. and that a further $15-25 \%$ have headache relief by 4 hours. Comparator studies have shown similar efficacy rates with the $50 \mathrm{mg}$ and $100 \mathrm{mg}$ tablets. There is evidence that doses of 50 and $100 \mathrm{mg}$ may provide greater effect than $25 \mathrm{mg}$.

If the migraine headache returns, or if a patient has a partial response to the initial dose, the dose may be repeated after 2 hours. Not more than $200 \mathrm{mg}$ should be taken in any 24 hour period.

If a patient does not respond to the first dose of IMITREX DF ${ }^{\mathrm{m}}$ Tablets, a second dose should not be taken for the same attack, as it is unlikely to be of clinical benefit IMITREX DF'M and IMITREX ${ }^{3}$ may be taken to treat subsequent migraine attacks.

The tablet should be swallowed whole with water, not crushed, chewed or split. Hepatic Impairment

In patients with mild or moderate hepatic impairment, plasma sumatriptan concentrations up to two times those seen in healthy subjects have been observed. Therefore, a $25 \mathrm{mg}$ dose (single tablet) may be considered in these patients (see PRECAUTIONS). Sumatriptan should not be administered to Injection

IMITREX Injection should be injected subcutaneously (on the outside of the thigh or in the upper arm) using an autoinjector.

The recommended adult dose of sumatriptan is a single $6 \mathrm{mg}$ subcutaneous

injection.
Clinical trials have shown that approximately $70-72 \%$ of patients have headache relief within one hour after a single subcutaneous injection. This number increases to $82 \%$ by 2 hours.

If the migraine headache returns. or if a patient has a partial response to the initial dose, the dose may be repeated after 1 hour. Not more than $12 \mathrm{mg}$ (two $6 \mathrm{mg}$ injections) should be taken in any 24 hour period.

If a patient does not respond to the first dose of IMITREX Injection, a second dose should not be taken for the same attack, as it is unlikely to be of clinical

Administration during migraine aura prior to other symptoms occurring may not prevent the development of a headache

Patients should be advised to read the patient instruction leaflet regarding the Nasal Spray

The minimal effective single adult dose of sumatriptan nasal spray is $5 \mathrm{mg}$. The maximum recommended single dose is $20 \mathrm{mg}$.

maximum recommended single dose is $20 \mathrm{mg}$.
If the migraine headache returns, or if a patient has a partial response to the initial dose, the dose may be repeated after 2 hours. Not more than $40 \mathrm{mg}$ should be taken in any 24 hour period.

In clinical studies totalling 3693 patients, optimal rates of headache relief were seen with the $20 \mathrm{mg}$ dose. Single doses above $20 \mathrm{mg}$ should not be used due to limited satety data and lack of increased efficacy relative to the $20 \mathrm{mg}$ single dose. Within the range of $5-20 \mathrm{mg}$, an increase in dose was not associated with any significant increase in the incidence or severity of adverse events other than taste disturbance (See ADVERSE REACTIONS).

The nasal spray should be administered into one nostril only. The device is a ready to use single dose unit and must not be primed betore administration.
Patients should be advised to read the patient instruction leaflet regarding the use of the nasal spray device before administration.

COMPOSITION

The TREX DFTM Tablets contain $100 \mathrm{mg}, 50 \mathrm{mg}$ or $25 \mathrm{mg}$ sumatriptan (base) as iron oxide red ( $100 \mathrm{mg}$ only), dibasic calcium phosphate anhydrous,
sodium bicarbonate, magnesium stearate, methylhydroxypropyl cellulose, microcrystalline cellulose, titanium dioxide, and triacetin.

IMITREX Injection contains $6 \mathrm{mg}$ sumatriptan (base) as the succinate salt in an Isotonic sodium chloride solution containing water for injection

MrREX Nasal Spray contains $5 \mathrm{mg}$, or $20 \mathrm{mg}$ of sumatriptan base (as the anhydrous dibasic sodium phosphate, monobasic potassium phosphate, purified water, sodium hydroxide and sulphuric acid

IMITREX DFTM Tablets are available as pink $100 \mathrm{mg}$, white $50 \mathrm{mg}$, or white $25 \mathrm{mg}$ film-coated tablets in blister packs containing 6 tablets

IMITREX Injection (6mg; total volume $=0.5 \mathrm{~mL}$ ) is available in prefilled syringes placed in a tamper-evident carrying/disposal case. Two pre-filled Syringes plus an IMITREX STATdose Pen ${ }^{T M}$ autoinjector are packed in an
IMITREX STATdose System ${ }^{\text {TM }}$ autoinjector kit. A refill pack is available containing 2 pre-filled syringes in a carton

Mitrinex lniection is also available 10 physicians or hospitals in a single dose

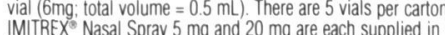

spray devices ( $3 \times 2$ devices). Each unit dose spray supplies 5 and $20 \mathrm{mg}$ respectively.

Product Monograph available to physicians and pharmacists upon request.

Please contact GlaxoSmithKline Inc., 7333 Mississauga Road N.. Mississauga, Ontario L5N 6L4.

IMITREX is a Is a trademark used under license by GlaxoSmithkline Inc. TMT The appearance, namely the colour shape, and size of the IMITREX Nasa Spray device and IMITREX STATdose System are trademarks, used under license by GlaxoSmithKline Inc.

Date of preparation: January 17, 1992

Date of revision: May 07, 2004

References: 1. Walls $C$ et al. Pharmacokinetic profile of a new form of sumatriptan tablets in healthy volunteers. Current Medical Research and Opinion in a fast-disintegrating, rapid-release formulation for the acute treatment of migraine: results of a multicenter, randomized, placebo-controlled study. Clin Therapeutics 2004:26(2):214-223. 3. Product Monograph AIMITREXD
succinate/sumatriptan) GlaxoSmithKline Inc. May 2004.

IMITREX DFTM and ZERO PAIN ${ }^{\text {TM }}$ are trademarks, used under license by IMITREX is a registered trademark, used under license by GlaxoSmithkline Inc Product Monograph available to health care professionals upon request.

\section{GlaxoSmithKline}

GlaxoSmithKline

Mississauga Road North

PAAB* R\&D 
NEW

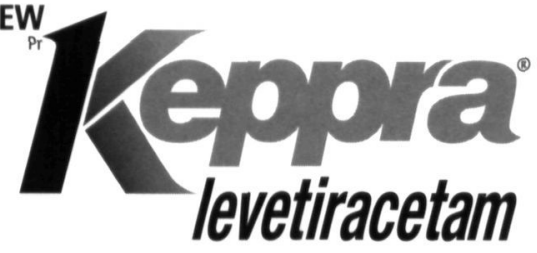

CONNECTING EXCELLENT PROFILES IN EFFICACY AND TOLERABILITY

PRESCRIBING INFORMATION

Tablets of $250 \mathrm{mg}, 500 \mathrm{mg}$, and $750 \mathrm{mg}$
Therapeutic classification: Antiepileptic

ACTIONS AND CLINICAL PHARMACOLOGY

\section{Mechanism of Action}

Levetiracetam is a drug of the pyrrolidine class chemically unrelated to existing antiepileptic drugs (AEDs). Levetiracetam exhibits antito existing antiepileptic drugs (AEDs). Levetiracetam exhibits antiepilepsy in both mice and rats, while being devoid of anticonvulsant epilepsy in both mice and rats, while being devoid of antic
activity in the classical screening models of acute seizures.

activity in the classical screening models of acute seizures.
The mechanism of action of levetiracetam has not yet been fully established, however, it appears to be unlike that of the commonly used AEDs. In vitro studies show that levetiracetam, at concentrations of up to $10 \mu \mathrm{M}$ did not result in significant ligand displacement at known receptor sites such as benzodiazepine, CABA (gamma aminobutyric acid), glycine, NMDA (N-methyl-D-aspartate), reuptake sites or second messenger systems. Furthermore, levetiracetam does not modulate neuronal voltage-gated sodium and T-type calcium currents and dos
facilitation of the CABAergic system.

Pharmacokinetics

Summary: Single- and multiple-dase pharmacokinetics of levetracetam have included healthy volunteers, adult and pediatric patients with epilepsy, elderly subjects, and subjects with renal and hepatic impairment. Results of these studies indicate that levetiracetam is rapidly and almost completely absorbed after oral administration. The pharmacokinetic profle is linear with low intraand inter-subject variability. There is no modification of the clearance after repeated administration. Food does not affect the extent of absorption of levetiracetam, although the rate is decreased. evetiracetam is not protein-bound ( $<10 \%$ bound) and its volume of distribution is close to the volume of intracellular and extracellular water. Sixty-six percent $(66 \%)$ of the dose is renally excreted
unchanged. The major metabolic pathway of levetiracetam ( $24 \%$ of the dose) is an enzymatic hydrolysis of the acetamide group. It is not iver cytochrome P450 dependent. The metabolites have no known pharmacodynamic activity and are renally excreted. Plasma half-life of levetiracetam across studies is 6-8 hours. Plasma half-life is increased in subjects with renal impairm
primarily due to impaired renal clearance.

Based on its pharmacokinetic characteristics, levetiracetam is unlikely to produce or to be subject to metabolic interactions.

The pharmacokinetic profile is comparable in healthy volunteers and in patients with epilepsy.

Due to its complete and linear absorption, plasma levels can be predicted from the oral dose of levetiracetam expressed as $\mathrm{mg} / \mathrm{kg}$ of levetiracetam.

\section{Human Pharmacology}

Pharmacokinetics: The pharmacokinetics of levetiracetam have been characterized in single and multiple dose PK studies, with doses up to $5000 \mathrm{mg}$; these studies included healthy volunteers $(n=98)$, patients with epilepsy $(n=58$ adult patients and $n=24$ pediatric patients), elderly subjects $(n=16)$ and subjects with renal and papatic impairment $(n=36$ and 16, respectively).

Absorption and Distribution: Levetiracetam is rapidly and almost Absorption and Distribution: Levetiracetam is rapidly and almost
completely absorbed after oral administration. The oral bioavailability of levetiracetam tablets is $100 \%$. Plasma peak bioavailability of levetiracetam tablets is $100 \%$. Plasma peak
concentrations ( $C_{\max }$ ) are achieved at 1.3 hours after dosing. The extent of absorption is independent of both dose and the presence of food, but the latter delays $T_{\max }$ by 1.5 hours and decreases $C_{\max }$ by $20 \%$. The pharmacokinetics of levetiracetam are linear over the dose range of $500-5000 \mathrm{mg}$. Steady-state is achieved after two days of a twice daily administration schedule. Mean peak concentrations
$\left(C_{\max }\right)$ are 31 and $43 \mu \mathrm{gg} / \mathrm{mL}$, respectively, following a single $1000 \mathrm{mg}$ dose, and a repeated $1000 \mathrm{mg}$ twice daily dose.

Neither levetiracetam nor its primary metabolite is significantly bound to plasma proteins $(<10 \%)$. The volume of distribution of levetiracetam is approximately 0.5 to $0.7 \mathrm{~L} / \mathrm{kg}$, a value that is close to the total body water volume. No tissue distribution data for humans are available.

Metabolism: Levetiracetam is not extensively metabolized in humans. The major metabolic pathway is the enzymatic hydrolysis of the acetamide group, which produces the pharmacologically nactive carboxylic a production of this metabolite is not dependent on any liver
cytochrome $\mathrm{P} 450$ isoenzymes and is mediated by serine esterase(s) cytochrome $P 450$ isoenzymes and is mediated by serine esterase(s)
in various tissues, including blood cells. Two minor metabolites were identified as the product of hydroxylation of the 2-oxo-pyrrolidine ring ( $2 \%$ of dose) and opening of the 2 -oxo-pyrrolidine ring in position 5 ( $1 \%$ of dose). There is no evidence for enantiomeric interconversion of levetiracetam or its major metabolite.

Elimination: Levetiracetam plasma half-life in adults is $7 \pm 1$ hours and was unaffected by dose, route of administration or repeated administration. Levetiracetam is eliminated from the systemic $66 \%$ of adminintered dose. The total body clearance is $0.96 \mathrm{~mL} / \mathrm{min} / \mathrm{kg}$ and the renal clearance is $0.6 \mathrm{~mL} / \mathrm{min} / \mathrm{kg}$. Approximately $93 \%$ of the dose was excreted with 48 hours. The mechanism of excretion is
glomerular filtration with subsequent partial tubular reabsorption. The primary metabolite, ucb L057, is excreted by glomerular filtration and active tubular secretion with a renal clearance of $4 \mathrm{~mL} \mathrm{~min} / \mathrm{kg}$.
Levetiracetam elimination is correlated to creatinine clearance and clearance is thus reduced in patients with impaired renal function clearance is thus reduced in patients with impaired renal fu
(See PRECAUTIONS and DOSAGE AND ADMINISTRATION).
Special Populations: Elderly: Pharmacokinetics of levetiracetam were evaluated in 16 elderly patients, ranging in age from 61-88 years, with 11 of the 16 patients aged 75 years of age or over with creatinin clearance ranging from 30 to $74 \mathrm{~mL} / \mathrm{min}$. Following oral administration of $500 \mathrm{mg}$ bid for 10 days, total body clearance decreased by $38 \%$ and the half-life was increased about $40 \%$ (10 to 11 hours) when compared to healthy adults. This is most likely due to the decrease in renal function in these subjects. Pediatrics (6 to 12 years): Pharmacokinetics of levetiracetam were evaluated in 24 pediatric patients (age 6-12 years) after a single dose. The apparent clearance of levetiracetam adjusted to body weight was approximately $40 \%$ higher than in epileptic adults. Gender: Levetiracetam $C_{\max }$ and AUC were $20 \%$ higher in women $(n=11)$ compared to men $(n=12)$. However, clearances adjusted for body weight were comparable. Race: Formal pharmacokinetic studies of the effects of race have not been conducted. Because levetiracetam is primarily renally excreted and there are no known important racial differences in creatinine clearance, significa

Renal Impairment: Single dose pharmacokinetics were performed in Renal Impairment: Single dose pharmacokinetics were performed in
20 subjects with renal impairment $(n=7$ mild $/ \mathrm{CL}$ cr of $50-79 \mathrm{~mL} / \mathrm{min}$ :

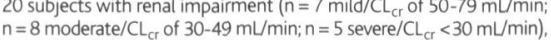
$n=8$ moderate/cL
and $n=11$ matching healthy volunteers. Clearance of levetiracetam is correlated with creatinine clearance and levetiracetam is correlated with creatinine clearance and levetiracetam
pharmacokinetics following repeat administration were well predicted from single dose data. The apparent body clearance of the parent drug levetiracetam is reduced in patients with impaired renal function by approximately $40 \%$ in the mild group, $50 \%$ in the moderate group, and $60 \%$ in the severe renal impairment group. Fo from baseline was greater than that seen for the parent drug in all subject groups.

In anuric (end stage renal disease) patients, the apparent body clearance was approximately $30 \%$ compared to that of normal
subjects. Approximately $50 \%$ of the pool of levetiracetam in the body is removed during a standard 4-hour hemodialysis procedure. Dosage should be reduced in patients with impaired renal function receiving levetiracetam, and supplemental doses should be given to patients after dialysis
ADMINISTRATION Hepatic Impairment: A single-dose pharmacokinetic study was
performed in 16 subjects with hepatic impairment $(n=5$ mild/ChildPugh Grade $A: n=6$ moderate/Crade $B: n=5$ severe/Grade $C$ vs 5 healthy controls). For the mild and moderate subgroups neither mean nor individual pharmacokinetic values were clinically different mean nor individual pharmacokinetic values were clinically different
from those of controls. In patients with severe hepatic impairment. mean apparent body clearance was $50 \%$ that of normal subjects. with decreased renal clearance accounting for most of the decrease. Patients with severe hepatic impairment thus require a reduced
dosage of Keppra ${ }^{\circledR}$ (See PRECAUTIONS and DOSAGE AND ADMINISTRATION)

INDICATIONS AND CLINICAL USE

Keppra (levetiracetam) is indicated as adjunctive therapy in the management of patients with epilepsy who are not satisfactorily controlled by conventional therapy.

\section{CONTRAINDICATIONS}

This product should not be administered to patients who have previously exhibited hypersensitivity to levetiracetam or any of the WARNINGS

\section{Central Nervous System Adverse Events}

Keppra (levetiracetam) use is associated with the occurrence of central nervous system (CNS) adverse events; the most significant of these can be classified into the following categories: 1) somnolence
and fatigue, 2) behavioral/psychiatric symptoms and 3) coordination difficulties.

There was no clear dose response relationship for any of the three categories of CNS adverse events, within the recommended dose range of up to $3000 \mathrm{mg} /$ day. Somnolence/asthenia and coordination difficulties occurred most frequently within the first four weeks of treatment and usually resolved while patients remained on treatment. In the case of behavioral/psychiatric symptoms (including such adverse events as aggression, agitation, anger, anxiety, emotiona lability, hostility, irritability), approximately half of the patients
reported these events within the first four weeks, with the remaining reported these events within the first four weeks, with the remaining
events occurring throughout the duration of the trials. See also events occurring throughout the duration of the trials,
PRECAUTIONS, Central Nervous System Adverse Events. Withdrawal of Anti-Epileptic Drugs

As with all antiepileptic drugs, Keppra should be withdrawn gradually to minimize the potential of increased seizure frequency.

\section{PRECAUTIONS}

General

Hematological Abnormalities: Minor but statistically significant decreases compared to placebo were seen in total mean RBC count, in controlled trials For hematocrit in Kepprad-treated patients Keppra or placebo treated patients with possibly clinically significant abnormalities were less than $0.5 \%$ each. For hematocrit values, a total of $5.1 \%$ of Keppra ${ }^{\circledR}$ treated versus $3.2 \%$ of placebo patients had at least one possibly significant decrease in hematocrit ( $37 \%$ in males and $32 \%$ in females).

For white blood cells (WBC), $2.9 \%$ of treated versus $2.3 \%$ of placebo patients had at least one possibly clinically significant decrease in placebo patients had at least one possibly significant decrease in neutrophil count $\left(\leq 1.0 \times 10^{9} / \mathrm{L}\right)$. Of the Keppra ${ }^{\mathscr{G}}$-treated patients with a low neutrophil count, all but one rose towards or reached baseline with continued treatment.
secondary to low neutrophil counts.

Central Nervous System Adverse Events (See WARNINGS): Kepprae (levetiracetam) use is associated with the occurrence of centra nervous system (CNS) adverse events; the most significant of these can be classified into the following categories: 1) somnolence and
fatigue, 2) behavioral/psychiatric symptoms and 3) coordination atigue, 2$)$,
difficulties.

The following CNS adverse events were observed in controlled The following
clinical trials.
Table 1:

Total Combined Incidence Rate for Each of the Three Categories of CNS Adverse Events in Placebo-controlled Add-on Clinical Trials

\begin{tabular}{|lcc|}
\hline $\begin{array}{l}\text { Category of CNS } \\
\text { adverse event }\end{array}$ & $\begin{array}{c}\text { Keppra } \\
\text { AED therapy } \\
(\mathbf{n}=672)\end{array}$ & $\begin{array}{c}\text { Placebo + } \\
\text { AED therapy } \\
(\mathbf{n}=351)\end{array}$ \\
\hline $\begin{array}{l}\text { Somnolence and fatigue } \\
\text { Somnolence }\end{array}$ & $15 \%$ & $10 \%$ \\
$\quad$ Asthenia & $14 \%$ & $10 \%$ \\
\hline $\begin{array}{l}\text { Behavioral/psychiatric symptoms } \\
\text { Nonpsychotic' } \\
\text { Psychotic }\end{array}$ & $14 \%$ & $6 \%$ \\
\hline Coordination difficulties $^{3}$ & $1 \%$ & $0 \%$ \\
\hline
\end{tabular}

Reflects Keppra? doses of $1000 \mathrm{mg}, 2000 \mathrm{mg}, 3000 \mathrm{mg}$, and $4000 \mathrm{mg}$ per day.

"Non-psychotic behavioral/psychiatric symptoms" encompasses the nalization, depression, emotional lability, euphoria, hostility, nervousness. neurosis, personality disorder and suicide attempt

"Psychotic behavioral/psychiatric symptoms" encompasses the following terms: hal

\section{"Coordination difficulties"}

See ADVERSE EVENTS, Table 2 ,

contained within the categories. Behavioral/psychiatric symptoms (including agitation, emotional lability, hostility, anxiety, etc.) have been reported approximately equally in patients with and without a psychiatric history.

There was no clear dose response relationship for any of the three categories of CNS adverse events, within the recommended dose range of up to $3000 \mathrm{mg} /$ day. In a controlled study including a dose of $4000 \mathrm{mg}$, administered without titration, the incidence rate of somnolence during the first four weeks of treatment for patients receiving the high dose was $42 \%$, compared to $21 \%$ for patients receiving $2000 \mathrm{mg} / \mathrm{da}$.

\section{Special Populations}

Patients with Renal Impairment: Renal excretion of unchanged drug accounts for approximately $66 \%$ of administered levetiracetam impaired patent with this, pharmacokinetic studies in renallyreduced in subjects with renal impairment (see ACTION AND CLINICAL PHARMACOLOGY, Special Populations.

In patients with renal impairment Keppra dosage should be appropriately reduced. Patients with end stage renal disease, i.e. those undergoing dialysis, should be given supplemental doses after dialysis (See DOSAGE AND ADMINISTRATION)

Pregnancy and Nursing: There are no adequate and well-controlled studies on the use of Keppra® in pregnant women. Levetiracetam and/or its metabolites cross the placental barrier in animal species. In reproductive toxicity studies in rats and rabbits, levetiracetam induced developmental toxicity at exposure levels similar to or greater than the human exposure. There was evidence of increased skeletal variations/minor anomalies, retarded growth, embryonic occurred in the absence of overt maternal toxicity. The systemic exposure at the observed no effect level in the rabbit was about 4 to 5 times the human exposure. The potential risk for humans is unknown. Keppra® should not be used during pregnancy unless potential benefits to mother and fetus are considered to outweigh potential benefits to mother and fetus are considered to outweigh may result in disease worsening, which can be harmful to the mother and the fetus.

Pregnancy Exposure Registry: To facilitate monitoring of feta outcomes of pregnant women exposed to Keppra , physicians
should encourage patients to register, before fetal outcome is known should encourage patients to register, before fetal outcome is known
(e.g.- ultrasound, results of amniocentesis, etc.), in the Antiepileptic Drug Pregnancy Registry by calling (888) 233-2334 (toll free). Nursing Mothers: Levetiracetam is excreted in breast milk. Therefore, there is a potential for serious adverse reactions from Keppra in nursing infants. Recommendations regarding nursing and epilepsy medication should take into account the importance of the drug to the mother, and the as yet uncharacterized risks to the infan Typically, recommendations are made in the context of the
necessary prior risk-benefit judgement, regarding pregnancy and necessary prior risk
epilepsy medication

Use in Pediatric Patients: Safety and efficacy in patients below the age of 18 have not been established.

Use in the Elderly: Renal function can be decreased in the elderly and levetiracetam is known to be substantially excreted by the kidney, the risk of adverse reactions to the drug may be greater in patients
with impaired renal function. A pharmacokinetic study in 16 elderly subjects (age 61-88 years) showed a decrease in clearance by about $40 \%$ with oral administration of both single dose and 10 days of multiple twice-daily dosing. This decrease is most likely due to the expected decrease in renal function in these elderly subjects. Care may be useful to monitor renal function.

There were insufficient numbers of elderly patients in controlled trials of epilepsy to adequately assess the efficacy or safety of Keppra in these patients. Nine of 672 patients treated with Keppra

Drug Interactions

In Vitro Studies on Metabolic Interaction Potential In vitro, levetiracetam and its primary metabolite have been shown not to
inhibit the major human liver cytochrome P450 isoforms (CYP3A4 inhibit the major human liver cytochrome P450 isoforms (CYP3A4 $2 \mathrm{~A} 6,2 \mathrm{CB} / 9 / 10,2 \mathrm{C} 19,2 \mathrm{D} 6,2 \mathrm{E} 1$ and $1 \mathrm{~A} 2)$, glucuronyl transferase (paracetamol UCT, i.e. UCT 1A6, ethinyl estradiol UGT, i.e.UCT 1AT, and $p$-nitrophenol UCT, i.e.UCT [p|6.2]) and epoxide hydrolase activities. In addition, levetiracetam does not affect the in vitro levetiracetam did not cause enzyme induction.

Levetiracetam circulates largely unbound ( $<10 \%$ bound) to plasma proteins; therefore clinically significant interactions with other drugs proteins; therefore clinically significant interactions with
through competition for protein binding sites are unlikely.

Thus in-vitro data, in combination with the pharmacokinetic characteristics of the drug, indicate that Keppra® is unlikely to produce, or be subject to, pharmacokinetic interactions 
Clinical Pharmacokinetic Data

Other Antiepileptic Drugs (AEDs): Potential drug interactions between Keppra and other AEDs (phenytoin, carbamazepine valproic acid, phenobarbital, lamotrigine, gabapentin and primidone were assessed by evaluating the serum concentrations of levetiracetam and these AEDs during placebo-controlled clinical studies These data suggest that levetiracetam may not significantly influence the plasma concentrations of these other AEDS, and that the other AEDS may not significantly influence the plasma concentrations of levetiracetam.

For two of these AEDs - phenytoin and valproate - forma pharmacokinetic interaction studies with Keppra were performed Keppra was co-administered with either phenytoin or valproate at doses of $3000 \mathrm{mg} /$ day and $1000 \mathrm{mg} /$ day respectively. No clinically significant interactions were observed.

\section{Other Drug Interactions}

Oral Contraceptives: A pharmacokinetic clinical interaction study has been performed in healthy subjects between the oral contraceptive containing $0.03 \mathrm{mg}$ ethinyl estradiol and $0.15 \mathrm{mg}$ levonorgesterol and the lowest therapeutic dose of Keppra (500 mg bid). No clinically significant pharmacokinetic interactions were observed.

However, pharmacokinetic interaction studies using Keppra as adjunctive therapy and covering the recommended dosage range have not been conducted. Therefore, physicians should advise thei female patients to be alert to any irregular vaginal bleeding or spotting, and to immediately report to them any occurrences.

Digoxin: Keppra (1000 mg bid) did not influence the pharmacokinetics and pharmacodynamics (ECG) of digoxin given as a $0.25 \mathrm{mg}$ dose every day. Coadministration of digoxin did not influence the pharmacokinetics of levetiracetam.

Warfarin: Keppra $\$(1000 \mathrm{mg}$ bid) did not influence the pharmacokinetics of $R$ and $S$ warfarin ( $2.5 \mathrm{mg} .5 \mathrm{mg}$, or $7.5 \mathrm{mg}$ daily) Prothrombin time was not affected by levetiracetam. Coadministration of warfarin did not affect the pharmacokinetics of levetiracetam

Probenecid: Probenecid, a renal tubular secretion blocking agent, administered at a dose of $500 \mathrm{mg}$ four times a day, did not change the pharmacokinetics of levetiracetam $1000 \mathrm{mg}$ bid. $C_{\text {ssmax }}$ of the metabolite, ucb L057, was approximately doubled in the presence of probenecid and the renal clearance of the metabolite ucb L057 was decreased by $60 \%$; this alteration is likely related to competitive inhibition of tubular secretion of ucb L057. The effect of Keppra on probenecid was not studied.

Commonly Observed

\section{ADVERSE EVENTS}

In well-controlled clinical studies, the most frequently reported adverse events associated with the use of Keppra in combination with other AEDs, not seen at an equivalent frequency among placebo-treated patients, were somnolence, asthenia, dizziness and infection. Of the most frequently reported adverse events, asthenia, somnolence and dizziness appeared to occur predominantly during the first four weeks of treatment with Kepprat.

Incidence of AEs in Controlled Clinical Trials

Table 2

Incidence (\%) of Treatment-emergent Adverse Events in Placebocontrolled, Add-on Studies by Body System. (Adverse Events Occurred in at least $1 \%$ of Keppra ${ }^{\star}$-treated Patients and Occurred More Frequently than Placebo-treated Patients.)

(Studies N051, N052, N132 and N138)

\begin{tabular}{|c|c|c|}
\hline $\begin{array}{l}\text { Body system/ } \\
\text { adverse event }\end{array}$ & $\begin{array}{c}\text { Keppra }^{\Phi+} \\
\text { AED therapy } \\
(n=672)(\%)\end{array}$ & $\begin{array}{l}\text { Placebo + } \\
\text { AED therapy } \\
(n=351)(\%)\end{array}$ \\
\hline $\begin{array}{l}\text { Body as a whole } \\
\text { Asthenia } \\
\text { Infection. }\end{array}$ & $\begin{array}{l}14 \\
13\end{array}$ & $\begin{array}{r}10 \\
7\end{array}$ \\
\hline $\begin{array}{l}\text { Digestive system } \\
\text { Tooth disorders }\end{array}$ & 2 & 1 \\
\hline $\begin{array}{l}\text { Hemic and } \\
\text { lymphatic system } \\
\text { Ecchymosis }\end{array}$ & 2 & 1 \\
\hline $\begin{array}{l}\text { Nervous system } \\
\text { Amnesia } \\
\text { Anxiety } \\
\text { Ataxia } \\
\text { Depression } \\
\text { Dizziness } \\
\text { Emotional lability } \\
\text { Hostility } \\
\text { Nervousness } \\
\text { Personality disorders } \\
\text { Somnolence } \\
\text { Thinking abnormal } \\
\text { Vertigo }\end{array}$ & $\begin{array}{r}2 \\
2 \\
3 \\
4 \\
9 \\
2 \\
2 \\
4 \\
1 \\
15 \\
2 \\
3\end{array}$ & $\begin{array}{r}0 \\
1 \\
1 \\
2 \\
4 \\
0 \\
1 \\
2 \\
0 \\
10 \\
1 \\
1\end{array}$ \\
\hline $\begin{array}{l}\text { Respiratory system } \\
\text { Pharyngitis } \\
\text { Rhinitis } \\
\text { Sinusitis }\end{array}$ & $\begin{array}{l}6 \\
4 \\
2\end{array}$ & $\begin{array}{l}4 \\
3 \\
1\end{array}$ \\
\hline
\end{tabular}
"In levetiracetam-treated patients, the majority of "infection" events
$(93 \%)$ were coded to reported terms of "common cold" or "infection (93\%) were coded
upper respiratory".

\section{Additional Events Observed in Placebo Controlled Trials}

Lack of Dose-related incidence within Therapeutic Range: Based on the data from the controlled clinical trials, there was no evidence of dose relationship within the recommended dose range of 1000 to $3000 \mathrm{mg} /$ day.

Discontinuation or Dose Reduction in Well-controlled Clinical Studies: In well-controlled clinical studies, $14.3 \%$ of patients receiving Keppra and $11.7 \%$ receiving placebo either discontinued or had a dose reduction as a result of an adverse event. The adverse events most commonly associated ( $>1 \%)$ with discontinuation or dose reduction in either treatment group are presented in Table 3.
Table 3:

Adverse Events Most Commonly Associated with Discontinuation or Dose Reduction in Placebo-controlled Studies in Patients with Epilepsy

\begin{tabular}{|lcc|}
\hline & $\begin{array}{c}\text { Keppra } \\
(n=672)\end{array}$ & $\begin{array}{l}\text { Placebo } \\
(n=351)\end{array}$ \\
\hline Asthenia & $9(1.3 \%)$ & $3(0.9 \%)$ \\
\hline Headache & $8(1.2 \%)$ & $2(0.6 \%)$ \\
\hline Convulsion & $16(2.4 \%)$ & $10(2.8 \%)$ \\
\hline Dizziness & $11(1.6 \%)$ & 0 \\
\hline Somnolence & $31(4.6 \%)$ & $6(1.7 \%)$ \\
\hline Rash & 0 & $5(1.4 \%)$ \\
\hline
\end{tabular}

The overall adverse experience profile of Keppra ${ }^{\circledR}$ was similar between females and males. There are insufficient data to support a statement regarding the distribution of adverse experience reports by age and race.

Post-marketing Experience

In post-marketing experience, nervous system and psychiatric disorders have most frequently been reported. In addition to adverse reactions during clinical studies, and listed above, the following adverse reactions have been reported in post-marketing experience. Data are insufficient to support an estimate of their incidence in the population to be treated.

Blood and lymphatic disorders: leukopenia, neutropenia, pancytopenia, thrombocytopenia.

\section{SYMPTOMS AND TREATMENT OF OVERDOSE}

ymptoms

The highest reported Keppra overdose is approximately 10 times the therapeutic dose. In the majority of overdose cases, multiple drugs were involved. Somnolence, agitation, aggression, depressed level of consciousness, respiratory depression, and coma wer observed with Keppra overdoses. The minimal lethal oral dose i rodents is at least 233 times the maximum clinically studied dose. Treatment

There is no antidote for overdose with Keppra-treatment is symptomatic and may include hemodialysis. If indicated, elimination of unabsorbed drug should be attempted by emesis or gastric lavage: usual precautions should be observed to maintain airway. Genera supportive care of the patient is indicated including monitoring of vital signs and observation of the clinical status of the patient. Standard hemodialysis procedures result in significant removal of levetiracetam (approximately $50 \%$ in 4 hours) and should be considered in cases of overdose. Although hemodialysis has not been performed in the few known cases of overdose, it may be indicated by the patient's clinical state or in patients with significant renal impairment.

\section{DOSAGE AND ADMINISTRATION}

General

Renal excretion of unchanged drug accounts for approximately $66 \%$ of administered levetiracetam dose. Consistent with this, reduced doses are recommended for patients with renal impairment.

Keppra is given orally with or without food

Adults

Treatment should be initiated at a dose of $1000 \mathrm{mg} /$ day, given as twice daily dosing ( $500 \mathrm{mg}$ bid). Depending on clinical response and tolerability, the daily dose may be increased every two weeks by increments of $1000 \mathrm{mg}$, to a maximum recommended daily dose of $3000 \mathrm{mg}$.

In dinical trials, daily doses of $1000 \mathrm{mg}, 2000 \mathrm{mg}$, and $3000 \mathrm{mg}$, given as twice a day dosing, were shown to be effective. Although there was a tendency toward greater response rate with higher dose, a consistent statistically significant increase in response with increased dose has not been shown. There are limited safety data from controlled clinical trials at doses higher than $3000 \mathrm{mg} /$ day (approximately 40 patients) therefore these doses are not recommended.

Patients with Impaired Renal Function

Keppra dosage should be reduced in patients with impaired renal function (see Table 4 below). Patients with end stage renal disease should receive supplemental doses following dialysis. To use this dosing table, an estimate of the patient's $\mathrm{CL}_{\mathrm{Cr}}$ in $\mathrm{mL} / \mathrm{min}$ is needed $\mathrm{CL}_{\text {cr }}$ in $\mathrm{mL} / \mathrm{min}$ may be estimated from serum creatinine $(\mathrm{mg} / \mathrm{dL}$ ) determination using the following formula:

$C_{L_{r}}=\frac{[140 \text {-age }(\text { years })] \times \text { weight }(\mathrm{kg})}{72 \times \text { serum creatinine }(\mathrm{mg} / \mathrm{dL})}(\times 0.85$ for female patients $)$

Table 4:

Dosing Adjustment for Patients with Impaired Renal Function

\begin{tabular}{|lll|}
\hline Group & $\begin{array}{l}\text { Creatinine } \\
\text { clearance } \\
\text { (mL/min) }\end{array}$ & $\begin{array}{l}\text { Dosage and } \\
\text { frequency }\end{array}$ \\
\hline Normal & 280 & 500 to $1500 \mathrm{mg}$ twice daily \\
Mild & $50-79$ & 500 to $1000 \mathrm{mg}$ twice daily \\
$\begin{array}{l}\text { Moderate } \\
\text { Severe" }\end{array}$ & $30-49$ & 250 to $750 \mathrm{mg}$ twice daily \\
$\begin{array}{l}\text { End-stage renal } \\
\text { disease patients } \\
\text { undergoing dialysis }\end{array}$ & - & 250 to $500 \mathrm{mg}$ twice daily \\
\hline
\end{tabular}

Following diatysis, a 250 to $500 \mathrm{mg}$ supplemental dose is recommended. or according to best clinical judgernent

Patients with Impaired Hepatic Function

No dose adjustment is needed in patients with mild-to-moderate hepatic impairment In patients with severe hepatic impairment the creatinine clearance may underestimate the renal insufficiency. Therefore a $50 \%$ reduction of the daily maintenance dose is recommended when the creatinine clearance is $<70 \mathrm{~mL} / \mathrm{min}$ Elderly Patient

Dose selection and titration should proceed cautiously in elderly patients, as renal function decreases with age.
PHARMACEUTICAL INFORMATION

U.S.A.N: levetiracetam

Chemical Name: (-)-(S)- $\alpha$-ethyl-2-oxo-1-pyrrolidine acetamide

Structural formula:<smiles>CC[C@H](C(N)=O)N1CCCC1=O</smiles>

Molecular Formula: $\mathrm{C}_{8} \mathrm{H}_{14} \mathrm{~N}_{2} \mathrm{O}_{2}$

Molecular Weight: 170.2

Physical form: A white to off-white crystalline powder with a faint odor and a bitter taste.

Solubility: It is very soluble in water $(104.0 \mathrm{~g} / 100 \mathrm{~mL})$. It is freely soluble in chtoroform $(65.3 \mathrm{~g} / 100 \mathrm{~mL})$ and in methanol $(53.6 \mathrm{~g} / 100 \mathrm{~mL})$ soluble in ethanol $(16.5 \mathrm{~g} / 100 \mathrm{~mL}$ ), sparingly soluble in acetonitrile $(5.7 \mathrm{~g} / 100 \mathrm{~mL})$ and practically insoluble in $\mathrm{n}$-hexane

pKa and $\mathrm{pH}$ values: The $\mathrm{pKa}$ of levetiracetam is $<-2$ and cannot be pKa and pH values: The pKa of levetiracetam is $<-2$ and cannot be
determined with accuracy due to the chemical instability of the protonated form.

The protonation of ucb LOS9 starts at $\mathrm{H}_{0}$ values between -1 and -2 . Partition Co-efficient: $\Delta \log P\left(\log P_{\text {octanol }}-\log P_{\text {cyclohexane }}\right)$ was calculated at $\mathrm{pH} 7.4$ using phosphate buffered saline and at $\mathrm{pH} 1.0$ using $\mathrm{KCl} / \mathrm{HCl}$. The $\Delta \log \mathrm{P}$ at $\mathrm{pH} 7.4$ is 3.65 and at $\mathrm{pH} 1.0$ is 3.10 . Melting Range: $115-119^{\circ} \mathrm{C}$

Composition: Keppra tablets contain the labeled amount of Covetiracetam Inactive ingredients include colloidal silicon dioxide corn starch, hydroxypropyl methylcellulose, magnesium stearate. polyethylene glycol 4000 . povidone, talc, titanium dioxide and coloring agents

The individual tablets contain the following coloring agents:

$250 \mathrm{mg}$ tablets: FD\&C Blue No. 2

$500 \mathrm{mg}$ tablets: FD\&C Blue No. 2 and yellow iron oxide

$750 \mathrm{mg}$ tablets: FD\&C Blue No. 2, FD\& C Yellow No. 6 and red iron oxide.

Stability and Storage Recommendations

Store between $15-30^{\circ} \mathrm{C}\left(59-86^{\circ} \mathrm{F}\right)$ AVAILABILITY OF DOSAGE FORMS

Keppra (levetiracetam) tablets, $250 \mathrm{mg}$ are blue, oblong-shaped, film-coated tablets debossed with "ucb" and "250" on one side. They are supplied in bottles of 120 tablets.

Keppra (levetiracetam) tablets, $500 \mathrm{mg}$ are yellow, oblong-shaped film-coated tablets debossed with "ucb" and "500" on one side. They are supplied in bottles of 120 tablets.

Keppra (levetiracetam) tablets, $750 \mathrm{mg}$ are orange. oblongshaped, film-coated tablets debossed with "ucb" and "750" on one side. They are supplied in bottles of 120 tablets.

For more information, please refer to the complete Keppra® Product Monograph.

References: 1. Cereghino J), Biton V, Abou-Khalil B, et al. Levetiracetam for partial seizures: results of a double-blind, randomized clinical trial. Neurology 2000;55:236-4. 2. Keppra Product Monograph. UCB Pharma, Inc.

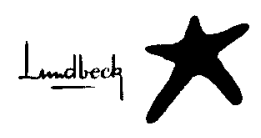

(1) Keppra is a registered trademark of UCB SA.

Keppra is distributed by Lundbeck Canada Inc.. 413 St-jacques St. West, Suite FB-230, Montreal, Quebec H2Y $1 \mathrm{~N} 9$ 


\section{${ }^{\circ}$ COPAXONE (glatiramer acetate injection)}

$20 \mathrm{mg}$, single use vials and $20 \mathrm{mg} / 1.0 \mathrm{~mL}$, pre-filled syringes for Subcutaneous Injection THERAPEUTIC CLASSIFICATION Immunomodulator

ACTION AND CLINICAL PHARMACOLOGY

COPAXONE [glatiramer acetate for iniection (formerly known as copolymer-1)] is a sterile, lyophilized mixture of synthetic polypeptides containing four naturally occurring amino acids: $L$-glutamic acid, $L$-alanine, L-tyrosine and L-lysine with an average molar fraction of $0.141,0.427,0.095$ and 0.338 , respectively.

The mechanism(s) by which glatiramer acetate exerts its effect on Multiple Sclerosis (MS) is (are) not fully elucidated. However, it is thought to act by modifying immune processes that are currently believed to be responsible for the pathogenesis of MS. This hypothesis is supported by findings of studies that have been carried out to explore the pathogenesis of experimental allergic encephalomyelitis (EAE), a condition induced in animals that is generally accepted as an serimental model of MS

Studies in animals and in vitro systems suggest that upon its administration glatiramer acetate specific suppressor $T$ cells are induced and activated in the periphery.

Because the immunological profile of glatiramer acetate remains to be fully elucidated, concerns exist about its potential to alter naturally occurring immune responses (see PRECAUTIONS)

Pharmacokinetics: Results obtained in pharmacokinetic studies performed in humans (healthy volunteers) and animals support the assumption that a substantial fraction of the therapeutic dose delivered to patients subcutaneously is hydrolyzed locally. Nevertheless, larger fragments of glatiramer acetate can be recognized by glatiramer acetate reactive antibodies. Some fraction of the injected material, either intact or partially hydrolyzed, is presumed to enter the lymphatic circulation, enabling it to reach regional lymph nodes, and some, may enter the systemic circulation intact.

Clinical Studies: The efficacy of COPAXONE" (glatiramer acetate for injection) was evaluated in two placebo-controlled trials in patients with Relapsing-Remitting MS (RR-MS). In a third placebo-controlled study the effects of glatiramer acetate on MRI parameters were assessed. In these studies, a dose of $20 \mathrm{mg} / \mathrm{day}$ was used. No other dose or dosing regimen has been studied in placebo-controlled trials of RR-MS

The first trial was a pilot study Trial 1 (Trial BR-I) which was conducted at a single-center and was a double-blind, randomized matched-pair, parallel group placebo-controlled trial. Fifty patients with RR-MS were randomized to receive $20 \mathrm{mg} / \mathrm{day}$ glatiramer acetate $(n=25)$ or placebo $(n=25)$ subcutaneously. The protocol-specified primary outcome measure was the proportion of patients who were relapse free during the 2-year duration of the trial, but two additional relevant outcomes were also specified as endpoints: frequency of attacks during the trial, and the change in the number of attacks compared to the rate of attacks in the 2 years prior to study entry. Results from this study (see Table 1) show that there was a statistically significant effect of glatiramer acetate on number of relapses.

TABLE 1 - Trial BR-1: Efficacy Results

\begin{tabular}{|l|c|c|c|}
\hline \multicolumn{1}{|c|}{ Outcome } & \multicolumn{3}{c|}{ Trial P } \\
\hline & $\begin{array}{c}\text { Clatiramer acetate } \\
\mathbf{n = 2 5}\end{array}$ & $\begin{array}{c}\text { Placebo } \\
\mathbf{n = 2 5}\end{array}$ & p-Value \\
\hline \% Relapse Free Patients & $14 / 25(56 \%)$ & $7 / 25(28 \%)$ & 0.085 \\
\hline Mean Relapse Frequency & $0.6 / 2$ years & $2.4 / 2$ years & 0.005 \\
\hline Reduction in Relapse Rate compared to pre-study & 3.2 & 1.6 & 0.025 \\
\hline Median Time to First Relapse (days) & $>700$ & 150 & 0.03 \\
\hline$\%$ of Progression-Free* Patients & $20 / 25(80 \%)$ & $13 / 25(52 \%)$ & 0.07 \\
\hline
\end{tabular}

The primary efficacy measure for Trial I was the proportion of patients who were re

of the trial (\% Relapse Free). Analyses were based on the intent-to-treat population.
- Progression defined as an increase of at least 1 point on the DSS that persists for at least 3 consecutive months.

Trial II (01-9001) was a multicenter double-blind, randomized, placebo-controlled trial. Two hundred and fifty-one patients with RR-MS were randomized to receive $20 \mathrm{mg} /$ day glatiramer acetate $(n=125)$ or placebo $(n=126)$ subcutaneously. Patients were diagnosed with RR-MS by standard criteria, and had at least 2 exacerbations during the 2 years immediately preceding enrollment. Patients had a score of no more than 5 on the Kurtzke Expanded Disability Scale Score (EDSS), a
standard scale ranging from 0 (normal) to 10 (death due to MS). A score of 5 is defined as one at which a patient is still ambulatory but for whom full daily activities are impaired due to disability, a score of 6 is defined as one at which the patient is still ambulatory but requires assistance and a score of 7 on this scale means that the patient requires a wheelchair.

Patients were seen every 3 months for 2 years, as well as within several days of a presumed exacerbation. In order for an exacerbation to be confirmed, a blinded neurologist had to document objective neurologic signs, as well as document the

The protocol-specified primary outcome measure was the mean number of relapses during treatment. Table 2 shows results of TABLE 2 - Core (24-month) Double-Blind Study: Effect on Relapse Rate

\begin{tabular}{|l|c|c|c|}
\hline \multicolumn{1}{|c|}{ Outcome } & \multicolumn{3}{c|}{ Trial II } \\
\hline & $\begin{array}{c}\text { Glatiramer acetate } \\
\mathbf{n = 1 2 5}\end{array}$ & $\begin{array}{c}\text { Placebo } \\
\mathbf{n = 1 2 6}\end{array}$ & p-Value \\
\hline Mean No. of Relapses/2 years & 1.19 & 1.68 & 0.055 \\
\hline \% Relapse Free Patients & $42 / 125(34 \%)$ & $34 / 126(27 \%)$ & 0.25 \\
\hline Median Time to First Relapse (days) & 287 & 198 & 0.23 \\
\hline \% of Patients Progression Free & $98 / 125(78 \%)$ & $95 / 126(75 \%)$ & 0.48 \\
\hline Mean Change in EDSS & -0.05 & +0.21 & 0.023 \\
\hline
\end{tabular}

The primary efficacy measure for Trial II was the number of relapses during treatment. Analyses were based on the intent-to-treat population

Progression defined as an increase of at least 1 point on the EDSS that persists for at least 3 consecutive months.

The effects of glatiramer acetate on relapse severity were not evaluated in either tria.

Both studies showed a beneficial effect of glatiramer acetate on relapse rate, and on this basis glatiramer acetate considered effective.

The third study (9003) was a multi-national, multi-center, MRI-monitored study. A total of 239 patients with RR-MS (119 on glatiramer acetate and 120 on placebo) were randomized. Inclusion criteria were similar to those in Trial II (Study 01-9001) with the additional criteria that patients had to have at least one Gd-enhancing lesion on the screening MRI. The patients were treated initially in a double-blind manner for nine months, during which they underwent monthly MRI scanning. The primary endpoint for the double-blind phase was the total cumulative number of $\mathrm{TI} C$ Cd-enhancing lesions over nine months. Other MRI parameters were assessed as secondary endpoints. Table 3 summarizes the results for the parameters monitored during the
nine-month double-blind phase for the intent-to-treat cohort. Because the link between MRI findings and the clinical status of patients is contentious, the prognostic value of the following statistically significant findings is unknown.

TABLE 3 - Nine-Month Double-Blind Phase: MRI Endpoints - Results

\begin{tabular}{|c|c|c|c|c|}
\hline No. & Outcome & $\begin{array}{c}\text { Glatiramer } \\
\text { acetate } n=113\end{array}$ & $\begin{array}{c}\text { Placebo } \\
\mathrm{n}=115\end{array}$ & p-Value \\
\hline \multicolumn{5}{|c|}{ Primary Endpoint } \\
\hline 1. & $\begin{array}{l}\text { Medians of the Cumulative Number of T1 } \\
\text { Gd-Enhancing Lesions }\end{array}$ & 12 & 17 & 0.0037 \\
\hline \multicolumn{5}{|c|}{ Secondary Endpoints } \\
\hline 2. & $\begin{array}{l}\text { Medians of the Cumulative Number of New T1 } \\
\text { Gd-Enhancing Lesions }\end{array}$ & 9 & 14 & 0.0347 \\
\hline 3. & Medians of the Cumulative Number of New T2 Lesions & 5 & 8 & 0.01 \\
\hline 4. & $\begin{array}{l}\text { Medians of the Cumulative Change from Baseline } \\
\text { in volumes (mL) of } \mathrm{T1} \mathrm{Gd} \text {-Enhancing Lesions }\end{array}$ & -0.309 & 0 & 0.0248 \\
\hline 5. & $\begin{array}{l}\text { Medians of the Cumulative Change from Baseline } \\
\text { in volumes ( } \mathrm{mL} \text { ) of T2 Lesions }\end{array}$ & 8.852 & 13.566 & 0.0229 \\
\hline 6. & $\begin{array}{l}\text { Medians of the Cumulative Change from Baseline } \\
\text { in volumes (mL) of T1 Hypointense Lesions }\end{array}$ & 1.642 & 1.829 & 0.7311 \\
\hline 7. & Proportion of T1 Gd-Enhancing Lesion-Free Patients & $46.4 \%$ & $32.2 \%$ & 0.0653 \\
\hline
\end{tabular}

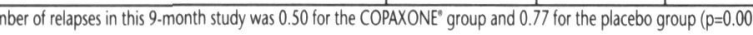

\section{NDICATIONS AND CLINICAL USE}

or use in ambulatory patients with Relapsing-Remitting Multiple Sclerosis to reduce the frequency of relapses.

The sarety and efficacy of COPAXONË in chronic progressive MS have not been established.

CONTRAINDICATIONS

COPAXONE' (glatiramer acetate for injection) is contraindicated in patients with known hypersensitivity to glatiramer acetate Or mannitol.

The only recommended route of administration of COPAXONE' (glatiramer acetate for injection) injection is the subcutaneous route. COPAXONE' should not be administered by the intravenous route.

Symptoms of Potentially Cardiac Origin: Approximately $26 \%$ of COPAXONE$^{*}$ patients in the pre-marketing multicenter controlled trial (compared to $10 \%$ of placebo patients) experienced at least one episode of what was described as transient chest pain (see ADVERSE REACTIONS: Chest Pain). While some of these episodes occurred in the context of the Immediate Post-Injection Reaction (see ADVERSE REACTIONS: Immediate Post-Injection Reaction), many did not. The pathogenesis of this symptom is unknown. Patients in controlled clinical trials were free of significant cardiovascular problems (New York Heart Association Class I and II) and thus the risks associated with COPAXONE" treatment for Multiple Sclerosis patients with comorbid cardiovascular disease are unknown.

COPAXONE has been associated with an Immediate Post-Injection Reaction consisting of a constellation of symptoms appearing immediately after injection that could include flushing, chest pain, palpitations, a

COPAXONE has not been studied in patients with a history of severe anaphylactoid reactions, obstructive pulmonary disease or asthma, nor in patients under treatment for either of these two latter conditions. Particular caution is therefore advised regarding the use of COPAXONE' in such patients.

Anaphylactoid reactions associated with the use of COPAXONE POst-marketing prioCAUTIONS

General: Patients should be instructed in aseptic reconstitution and self-iniection techniques to assure the safe administration of COPAXONE' (glatiramer acetate for injection) (see INFORMATION FOR THE PATIENT). The first injection should be performed under the supervision of an appropriately qualified health care professional. Patient understanding and use of aseptic self-injection techniques and procedures should be periodically re-evaluated. Patients should be cautioned against the re-use of needles or syringes and instructed in safe disposal procedures. A puncture-resistant container for disposal of used needles and syringes should be used by the patient. Patients should be instructed on the safe disposal of full containers.

Considerations Involving the Use of a Product Capable of Modifying Immune Responses: COPAXONE" is an antigenic substance and thus it is possible that detrimental host responses can occur with its use. Whether COPAXONE* can alter normal human immune responses, such as the recognition of foreign antigens is unknown. It is therefore possible that reatment with COPAXONE' may undermine the body's defenses against infections and tumor surveillance. Systematic assessments of these risks have not been done. Continued alteration of cellular immunity due to chronic treatment with glatiramer acetate might result in untoward effects.

Glatiramer acetate-reactive antibodies are formed in practically all patients exposed to daily treatment with the recommended dose. Studies in both the rat and monkey have suggested that immune complexes are deposited in the renal glomeruli. Furthermore, in a controlled clinical trial of 125 RR-MS patients given glatiramer acetate $20 \mathrm{mg}$ for 2 years, serum $\mathrm{lgC}$ levels reached at least 3 times baseline values in $80 \%$ of patients by 3 months of initiation of treatment. By 12 months of treatment, however, $30 \%$ of patients still had lgC levels at least 3 times baseline values, and $90 \%$ had levels above baseline by 12 months. The antibodies are exclusively of the lgG subtype - and predominantly of the lgG-1 1 subtype. No lgE type antibodies could be detected in any of the 94 sera tested. Nevertheless, anaphylaxis can be associated with the type antibodies could be detected in any of the 94 sera tested. Nevertheless, anaphy
administration of almost any foreign substance and, therefore, this risk cannot be excluded.

Preclinical studies to assess the carcinogenic potential of glatiramer acetate in mice and rats do not suggest any evidence of carcinogenic potential related to glatiramer acetate administered subcutaneously at dose levels of up to $30 \mathrm{mg} / \mathrm{kg} / \mathrm{day}$ in rats and $60 \mathrm{mg} / \mathrm{kg} /$ day in mice (see TOXICOLOCY: Carcinogenicity). The relevance of these findings for humans is un
(see PRECAUTIONS: Considerations Involving the Use of a Product Capable of Modifying Immune Responses). Drug Interactions: Interactions between COPAXONE"s and other drugs have not been fully evaluated. Results from existing clinical trials do not suggest any significant interactions of COPAXONE" with therapies commonly used in MS patients. This includes the concurrent use of corticosteroids for up to 28 days. COPAXONE" has not been formally evaluated in combination with Interferon beta. However, 246 patients who failed on or who did not tolerate therapy with Interferon beta combination with Interferon beta. However, 246 patients who failed on or who did not tolerate therapy with Interferon beta
and were later treated with COPAXONE' within the framework of an open clinical trial did not report any serious or unexpected adverse events thought to be related to treatment.

Use in Pregnancy: There are no adequate and well-controlled studies in pregnant women. No evidence of reproductive oxicity was observed in preclinical studies (see TOXICOLOCY: Reproduction and Teratology). Because animal reproduction studies are not always predictive of human response, this drug should be used during pregnancy only if clearly needed. During pre-marketing clinical trials with COPAXONE', seven women conceived while being treated with the active drug. One case was lost to follow-up. Three of the patients electively discontinued pregnancy.
months after learning they were pregnant; all delivered healthy babies.

Nursing Mothers: It is not known whether this drug is excreted in human milk. Because many drugs are excreted in human milk, treating a nursing woman with COPAXONE* should only be considered after careful risk/benefit assessment and be used with caution.

Use in Children: The safety and effectiveness of COPAXONE" have not been established in individuals below 18 years of age. Use in the Elderly: COPAXONE" has not been studied in the elderly ( $>65$ years old).

Use in Patients with Impaired Renal Function: The pharmacokinetics of COPAXONE' in patients with impaired renal unction have not been determined.

\section{ADVERSE REACTIONS}

the pre-marketing clinical trials, approximately 900 individuals have received at least one dose of COPAXONE* (glatiramer acetate for injection) in controlled and uncontrolled clinical trials. Total patient exposure to $\mathrm{COPAXONE}^{\circ}$ in clinical trials ranged from 6 months ( 693 patients) to 2 years ( 306 patients), and to over 7 years ( 69 patients) at a daily dose of $20 \mathrm{mg}$. In controlled clinical trials, the most commonly observed adverse events associated with the use of COPAXONE" which occurred at a higher frequency than in placebo treated patients were: injection site reactions, vasodilation, chest pain, asthenia, infection, pain, nausea, arthralgia, anxiety and hypertonia.

Of a total of 844 patients who could be evaluated for safety, approximately $8 \%$ discontinued treatment due to an adverse even The adverse events most commonly associated with discontinuation were: injection site reaction (6.5\%),
vasodilation, unintended pregnancy, depression, dyspnea, urticaria, tachycardia, dizziness and tremor. Treatmen discontinuation due to a serious adverse event considered by investigators to be related to COPAXONE" treatment included case of life-threatening serum sickness.

Immediate Post-Injection Reaction: Approximately $10 \%$ of Multiple Sclerosis patients exposed to COPAXONE ${ }^{\circ}$ i pre-marketing studies reported a post-injection reaction immediately following subcutaneous injection of COPAXONE Symptoms experienced could include flushing, chest pain, palpitations, anxiety, dyspnea, constriction of the throat and urticaria. These symptoms were invariably transient, self-limited, did not require specific treatment and in general, arose several months after initiation of treatment, although they may occur earlier in the course of treatment. A given patient may mediated by an immunologic or non-immunologic mechanism, and whether several similar episodes seen in a given patient have identical mechanisms is unknown. In fact, whether or not this constellation of symptoms actually represents a have identical mechanisms is unknown. In fact, whether or not this constellation of symptoms actually represents a
specific syndrome is unknown. During the post-marketing period, there have been reports of patients with similar specific syndrome is unknown. During the post-marketing period,
symptoms who received emergency medical care (see WARNINCS).

Chest Pain: Approximately $26 \%$ of glatiramer acetate patients in the multicenter pre-marketing controlled trial (compared to $10 \%$ of placebo patients) experienced at least one episode of what was described as transient chest pain. While some of thes episodes occurred in the context of the Immediate Post-Injection Reaction described above, many did not. The tempora relationship of the chest pain to an injection of glatiramer acetate was not always known, although the pain was transien (usually lasting only a few minutes), often unassociated with other symptoms, and appeared to have no important clinical sequelae. Some patients experienced more than one such episode, and episodes usually began at least 1 month after the initiation of treatment. The pathogenesis of this symptom is unknown. There has been only one episode of chest pain during which a full ECC was performed; the ECC showed no evidence of ischemia. Patients in clinical trials were free of significant cardiovascular disease (New York Heart Association Class I or II); therefore, the risks associated with glatiramer acetate treatment for Multiple Sclerosis

Table 4 lists the adverse experiences after up to 35 months of treatment (>27-33 months: COPAXONE*, $n=84$; Placebo, $n=75 ;>33$ months: COPAXONE*, $n=12 ;$ Placebo, $n=24$ ) in the pre-marketing multicenter placebo-controlled study (Trial II) in relapsing-remitting Multiple Sclerosis patients that occurred at an incidence of at least $2 \%$ among patients who (Trial II) in relapsing-remitting Muitiple Sclerosis patients that occurred at an incidence of at least $2 \%$ among patients who
received COPAXNE" and at an incidence that was at least $2 \%$ more than that observed in the same trial for placebo patients regardless of their causal relationship to treatment. No laboratory adverse experiences that met these criteria

It should be noted that the figures cited in Table 4 cannot be used to predict the incidence of side effects during the course of usual medical practice, where patient characteristics and other factors differ from those that prevailed in the clinical
trials. However, the cited figures do provide the prescribing physician with some basis for estimating the relative contribution trials. However, the cited figures do provide the prescribing physician with some basis for es
of drug and non-drug factors to the adverse event incidence rate in the population studied. 
TABLE

Pre-marketing Controlled Trial in Patients with Multiple Sclerosis

Adverse Experiences $>2 \%$ Incidence and $>2 \%$ Above Placebo

\begin{tabular}{|c|c|c|c|c|}
\hline \multirow[b]{2}{*}{ Adverse Experience } & \multicolumn{2}{|c|}{$\begin{array}{c}\text { COPAXONE } \\
n=125\end{array}$} & \multicolumn{2}{|c|}{$\begin{array}{c}\text { Placebo } \\
n=126\end{array}$} \\
\hline & n & $\%$ & $n$ & $\%$ \\
\hline $\begin{array}{l}\text { Body as a Whole } \\
\text { Injection Site Pain } \\
\text { Asthenia } \\
\text { Injection Site Erythema } \\
\text { Injection Site Pruritus } \\
\text { Flu syndrome } \\
\text { Injection Site Inflammation } \\
\text { Back pain } \\
\text { Chest pain } \\
\text { Injection Site Mass } \\
\text { Injection Site Induration } \\
\text { Injection Site Welt } \\
\text { Neck pain } \\
\text { Face Edema } \\
\text { Injection Site Urticaria } \\
\text { Injection Site Hemorrhage } \\
\text { Chills } \\
\text { Cyst } \\
\text { Injection Site Reaction } \\
\text { Injection Site Atrophy } \\
\text { Abscess }\end{array}$ & $\begin{array}{l}83 \\
81 \\
73 \\
48 \\
38 \\
35 \\
33 \\
33 \\
33 \\
25 \\
19 \\
16 \\
11 \\
9 \\
8 \\
5 \\
5 \\
4 \\
3 \\
3 \\
\end{array}$ & $\begin{array}{l}66.4 \\
64.8 \\
58.4 \\
38.4 \\
30.4 \\
28.0 \\
26.4 \\
26.4 \\
26.4 \\
20.0 \\
15.2 \\
12.8 \\
8.8 \\
7.2 \\
6.4 \\
4.0 \\
4.0 \\
3.2 \\
2.4 \\
2.4 \\
\end{array}$ & $\begin{array}{c}46 \\
78 \\
17 \\
17 \\
34 \\
9 \\
28 \\
13 \\
10 \\
1 \\
5 \\
9 \\
2 \\
0 \\
4 \\
1 \\
1 \\
1 \\
0 \\
0 \\
\end{array}$ & $\begin{array}{c}36.5 \\
61.9 \\
13.5 \\
4.0 \\
27.0 \\
7.1 \\
22.2 \\
10.3 \\
7.9 \\
0.8 \\
4.0 \\
7.1 \\
1.6 \\
0 \\
3.2 \\
0.8 \\
0.8 \\
0.8 \\
0 \\
0\end{array}$ \\
\hline $\begin{array}{l}\text { Cardiovascular } \\
\text { Vasodilatation } \\
\text { Palpitation } \\
\text { Migraine } \\
\text { Syncope }\end{array}$ & $\begin{array}{l}34 \\
14 \\
9 \\
8\end{array}$ & $\begin{array}{l}27.2 \\
11.2 \\
7.2 \\
6.4\end{array}$ & $\begin{array}{l}14 \\
6 \\
5 \\
4\end{array}$ & $\begin{array}{l}11.1 \\
4.8 \\
4.0 \\
3.2\end{array}$ \\
\hline $\begin{array}{l}\text { Digestive } \\
\text { Nausea } \\
\text { Vomiting } \\
\text { Anorexia } \\
\text { Castroenteritis } \\
\text { Oral Moniliasis } \\
\text { Tooth Caries } \\
\end{array}$ & $\begin{array}{c}29 \\
13 \\
6 \\
6 \\
3 \\
3 \\
\end{array}$ & $\begin{array}{l}23.2 \\
10.4 \\
4.8 \\
4.8 \\
2.4 \\
2.4 \\
\end{array}$ & $\begin{array}{c}22 \\
7 \\
3 \\
2 \\
0 \\
0 \\
\end{array}$ & $\begin{array}{l}17.5 \\
5.6 \\
2.4 \\
1.6 \\
0 \\
0\end{array}$ \\
\hline $\begin{array}{l}\text { Hemic and Lymphatic } \\
\text { Lymphadenopathy } \\
\text { Ecchymosis }\end{array}$ & $\begin{array}{l}23 \\
15\end{array}$ & $\begin{array}{l}18.4 \\
12.0\end{array}$ & $\begin{array}{l}12 \\
12\end{array}$ & $\begin{array}{l}9.5 \\
9.5\end{array}$ \\
\hline $\begin{array}{l}\text { Metabolic and Nutritional } \\
\text { Peripheral Edema } \\
\text { Weight gain } \\
\text { Edema } \\
\end{array}$ & $\begin{array}{c}14 \\
7 \\
5 \\
\end{array}$ & $\begin{array}{l}11.2 \\
5.6 \\
4.0\end{array}$ & $\begin{array}{l}7 \\
0 \\
1 \\
\end{array}$ & $\begin{array}{c}5.6 \\
0 \\
0.8\end{array}$ \\
\hline $\begin{array}{l}\text { Musculo-Skeletal } \\
\text { Arthralgia } \\
\end{array}$ & 31 & 24.8 & 22 & 17.5 \\
\hline $\begin{array}{l}\text { Nervous System } \\
\text { Hypertonia } \\
\text { Tremor } \\
\text { Agitation } \\
\text { Confusion } \\
\text { Nystagmus }\end{array}$ & $\begin{array}{l}44 \\
14 \\
7 \\
5 \\
5\end{array}$ & $\begin{array}{l}35.2 \\
11.2 \\
5.6 \\
4.0 \\
4.0\end{array}$ & $\begin{array}{l}37 \\
7 \\
4 \\
1 \\
2\end{array}$ & $\begin{array}{l}29.4 \\
5.6 \\
3.2 \\
0.8 \\
1.6\end{array}$ \\
\hline $\begin{array}{l}\text { Respiratory } \\
\text { Rhinitis } \\
\text { Dyspnea } \\
\text { Bronchitis } \\
\end{array}$ & $\begin{array}{l}29 \\
23 \\
18\end{array}$ & $\begin{array}{l}23.2 \\
18.4 \\
14.4\end{array}$ & $\begin{array}{c}26 \\
8 \\
12 \\
\end{array}$ & $\begin{array}{r}20.6 \\
6.4 \\
9.5\end{array}$ \\
\hline $\begin{array}{l}\text { Skin and Appendages } \\
\text { Sweating } \\
\text { Erythema } \\
\text { Skin Disorder } \\
\text { Skin Nodule } \\
\text { Wart } \\
\end{array}$ & $\begin{array}{l}15 \\
8 \\
5 \\
4 \\
3 \\
\end{array}$ & $\begin{array}{l}12.0 \\
6.4 \\
4.0 \\
3.2 \\
2.4\end{array}$ & $\begin{array}{l}10 \\
4 \\
2 \\
1 \\
0\end{array}$ & $\begin{array}{c}7.9 \\
3.2 \\
1.6 \\
0.8 \\
0\end{array}$ \\
\hline $\begin{array}{l}\text { Special Senses } \\
\text { Ear Pain } \\
\text { Eye Disorder }\end{array}$ & $\begin{array}{c}15 \\
8 \\
\end{array}$ & $\begin{array}{c}12.0 \\
6.4\end{array}$ & $\begin{array}{c}12 \\
1\end{array}$ & $\begin{array}{l}9.5 \\
0.8\end{array}$ \\
\hline $\begin{array}{l}\text { Urogenital System } \\
\text { Urinary Urgency } \\
\text { Vaginal Moniliasis } \\
\text { Dysmenorrhea } \\
\text { Unintended Pregnancy } \\
\text { Impotence }\end{array}$ & $\begin{array}{c}20 \\
16 \\
12 \\
4 \\
3\end{array}$ & $\begin{array}{l}16.0 \\
12.8 \\
9.6 \\
3.2 \\
2.4\end{array}$ & $\begin{array}{l}17 \\
9 \\
9 \\
0 \\
0\end{array}$ & $\begin{array}{c}13.5 \\
7.1 \\
7.1 \\
0 \\
0\end{array}$ \\
\hline
\end{tabular}

Other events which occurred in at least $2 \%$ of patients but were present at equal or greater rates in the placebo group included Body as a whole: Headache, injection site ecchymosis, accidental injury, abdominal pain, allergic rhinitis and malaise. Digestive System: Dyspepsia, constipation, dysphagia, fecal incontinence, flatulence, nausea and vomiting, gastritis, gingivitis, periodontal abscess, and dry mouth. Musculo-Skeletal: Myasthenia and myalgia. Nervous System: Dizziness, hypesthesia paresthesia, insomnia, depression, dysesthesia, incoordination, somnolence, abnormal gait, amnesia, emotional lability Lhermitte's sign, abnormal thinking, twitching, euphoria, and sleep disorder. Respiratory System: Pharyngitis, sinusitis, increased cough and laryngitis. Skin and Appendages: Acne, alopecia, and nail disorder. Special Senses: Abnormal vision diplopia, amblyopia, eye pain, conjunctivitis, tinnitus, taste perversion, and deafness. Urogenital System: Urinary tract infec tion, urinary frequency, urinary incontinence, urinary retention, dysuria, cystitis, metrorrhagia, breast pain, and vaginitis.
Data on adverse events occurring in the controlled clinical trials were analyzed to evaluate gender related differences. No Data on adverse events occurring in the controlled clinical trials were analyzed to evaluate gender related differences. No
clinically significant differences were identified. In these clinical trials $92 \%$ of patients were Caucasian, which is representative clinically significant differences were identified. In these clinical trials $92 \%$ of patients were Caucasian, which is representative
of the population of patients with Multiple Sclerosis. In addition, the vast majority of patients treated with COPAXONE between the ages of 18 and 45 . Consequently, inadequate data are available to perform an analysis of the incidence of adverse events related to clinically relevant age subgroups.

Laboratory analyses were performed on all patients participating in the clinical program for COPAXONE'. Clinically significant changes in laboratory values for hematology, chemistry, and urinalysis were similar for both COPAXONE' and placebo group in blinded clinical trials. No patient receiving COPAXONE" with
other Adverse Events Observed During All Clinical Trials

Other Adverse Events Observed During All Clinical Trials

COPAXONE" has been administered to approximately 900 individuals during clinical trials, only some of which were placebocontrolled. During these trials, all adverse events were recorded by clinical investigators using terminology of their ow choosing. To provide a meaningful estimate of the proportion of individuals having adverse events, similar types of events were
grouped into a smaller number of standardized categories using COSTART II dictionary terminology. All reported events that grouped into a smaller number of standardized categories using COSTART II dictionary terminology. All reported events that
occurred at least twice and potentially important events occurring once, are included except those already listed in the previous occurred at least twice and potentially important events occurring once, are included except those already listed in the previous
table, those too general to be informative, trivial events, and other events which occurred in at least $2 \%$ of treated patients and were present at equal or greater rates in the placebo group.

Events are further classified within body system categories and enumerated in order of decreasing frequency using the following definitions: Frequent adverse events are defined as those occurring in at least 1/100 patients; infrequent adverse events are those occurring in 1/100 to 1/1000 patients. Body as a whole: Frequent: Injection site edema, injection site atrophy, abscess and injection site hypersensitivity. Infrequent: Injection site hematoma, injection site fibrosis, moon face, cellul tis, generalized edema, hernia, injection site abscess, serum sickness, suicide attempt, injection site hypertrophy, injection site melanosis, lipoma and photosensitivity reaction. Cardiovascular: Frequent: Hypertension. Intrequent: Hypotension midsystolic click, systolic murmur, atrial fibrillation, bradycardia, fourth heart sound, postural hypotension and varicose vein Digestive: Infrequent: Dry mouth, stomatitis, burning sensation on tongue, cholecystitis, colitis, esophageal uker, esophagitis, gastrointestinal carcinoma, gum hemorrhage, hepatomegaly, increased appetite, melena, mouth ukeration, pancreas disorde pancreatitis, rectal hemorrhage, tenesmus, tongue discolouration and duodenal ulcer. Endocrine: Infrequent: Goiter, hype thyroidism, and hypothyroidism. Gastrointestinal: Frequent: Bowel urgency, oral moniliasis, salivary gland enlargement, tooth canes, and ukceratice stomauts. Hemic and Lymphatic: Infrequent: Leukopenia, anemia, cyanosis, eosinophilia, hemateme sis, lymphedema, pancytopenia, and splenomegaly. Metabolic and Nutritional: Infrequent: Weight loss, alcohol intolerance pain, bursitis, kidney pain, muscle disorder, myopathy, osteomyelitis, tendon pain, and tenosynovitis. Nervous: Frequent pain, bursitis, kidney pain, muscle disorder, myopathy, osteomyelitis, tendon pain, and tenosynovitis. Nervous: Frequent: Abnormal dreams, emotional lability, and stupor. Intrequent: Aphasia, ataxia, convulsion, circumoral paresthesia, depersontion, memory impairment, myoclonus, neuralgia, paranoid reaction, paraplegia, psychotic depression and transient stupor
Respiratory: Frequent: Hyperventilation, hav-fever. Infrequent: Asthma, pneumonia, epistaxis, hypoventilation, and voice alteration. Skin and Appendages: Frequent: Eczema, herpes zoster, pustular rash, skin atrophy and warts. Infrequent: Dry skin, skin hypertrophy, dermatitis, furunculosis, psoriasis, angioedema, contact dermatitis, erythema nodosum, fungal dermatitis, maculopapular rash, pigmentation, benign skin neoplasm, skin carcinoma, skin striae, and vesiculobullous rash, Special Senses: Frequent: Visual field defect. Infrequent: Dry eyes, otitis externa, ptosis, cataract, corneal ulcer, mydriasis, optic neuritis, photophobia, and taste loss. Urogenital: Frequent: Amenorrhea, hematuria, impotence, menorrhagia, suspicious
Papanicolaou smear, urinary frequency and vaginal hemorrhage. Intrequent: Vaginitis, flank pain (kidney), abortion, breast engorgement, breast enlargement, breast pain, carcinoma cervix in situ, fibrocystic breast, kidney calculus, nocturia, ovarian engorgement, breast enlargement, breast pain, carcinoma cervx in stu,

\section{Adverse Events Reported Post-Marketing and Not Previously Noted in Clinical Trials}

Post-marketing experience has shown an adverse event profile similar to that presented above. Reports of adverse reactions occurring under treatment with COPAXONE" ( glatiramer acetate for injection) not mentioned above, that have been received since market introduction and that may have or not have causal relationship to the drug include the following: Body as a whole: Sepsis, LE syndrome, hydrocephalus, enlarged abdomen, injection site hypersensitivity, allergic reaction, naphylactoid reaction, bacterial infection, fever, infection. Cardiovascular: Thrombosis, peripheral vascular disease, pericardial effusion, myocardial infarct, deep thrombophlebitis, coronary occlusion, congestive heart failure, cardiomyopathy cardiomegaly, arrhythmia, angina pectoris, tachycardia. Digestive: Tongue edema, stomach ulcer hemorrhage, iver function abnormality, liver damage, hepatitis, eructation, cirmosis of the liver, cholelithiasis, diarrhea, gastrointestinal disorder. Hemic and Lymphatic. Thembcytopenia, lymphoma-like reaction, acule leukemia. Metabolic and Nutritional: Hypercholesteremia. Musculoskeletal: Rheumatoid arthritis, generalized spasm. Nervous: Myelitis, meningitis, CNS neoplasm, cerebrovascular accident, brain edema, abnormal dreams, aphasia, convulsion, neuralgia, anxiety, foot drop, nervousness, speech disorder, vertigo. Respiratory: Pulmonary embolus, pleural effusion, carcinoma of lung, hay fever, laryngismus. Skin and Appendages: Herpes simplex, pruritis, rash, urticaria. Special Senses: Glaucoma, blindness, visual field defect. Urogenital: Urogenital neoplasm, urine abnormality, ovarian carcinoma, nephrosis, kidney failure, breast carcinoma,

\section{SYMPTOMS AND TREATMENT OF OVERDOSAGE}

Overdose with COPAXONE" has been reported in three patients. One patient injected four doses ( $80 \mathrm{mg}$ total) of COPAXONE at once. No sequelae were noted. Two other patients, a 28 -year old male and a 37-year old female, were given 3 injections of $20 \mathrm{mg}$ of COPAXONE" at one half hour intervals by error. Neither patient evidenced any change in blood pressure, heart rate,

\section{or temperature. Telephone follow-up ser}

COPAXONE" should only be prescribed by (or following consultation with) clinicians who are experienced in the diagnosis and management of Multiple Sclerosis.

The recommended dose of COPAXONE: (glatiramer acetate for injection or glatiramer acetate injection) for the treatment of relapsing-remitting MS is a daily injection of $20 \mathrm{mg}$ given subcutaneously.

Instructions for Use: To reconstitute lyophilized COPAXONE" for injection, use a sterile syringe and adapter to transfer $1.1 \mathrm{~mL}$ of the diluent supplied, Sterile Water for Injection, into the COPAXONE' vial. Gently swir the vial of COPAXONE' and let stand at room temperature until the solid material is completely dissolved. Inspect the reconstituted product visually and discard or return the product to the pharmacist before use if it contains particulate matter. Use within 8 hours after reconstitution. Withdraw $1.0 \mathrm{~mL}$ of the solution into a sterile syringe. Remove the adapter, connect a 27-gauge needle and inject the solution subcutaneously. Sites for self-injection include arms, stomach (abdomen), buttocks, and thighs. A vial is suitable for single use only; unused portions should be discarded (see INFORMATION FOR THE PATIENT: Reconstituted produc).

For the pre-filled syringe of COPAXONE', please see the INFORMATION FOR THE PATIENT: pre-filled syringe for instructions on the preparation and in

\section{Drug Substance}

\section{Proper Name: Glatiramer acetate}

Clatiramer acetate is the acetate salt of synthetic polypeptides.

Description: Glatiramer acetate is prepared by chemically reacting the activated derivatives of four amino acids: L-glutamic acid (L-Glu), L-alanine (L-Ala), L-tyrosine (L-Tyr), and L-lysine (L-Lys) in a specitied ratio. The molar fraction of each amino acid residue ranges as follows: L-Clu 0.129-0.153, L-Ala 0.392-0.462, L-Tyr 0.086-0.100 and L-Lys $0.300-0.374$

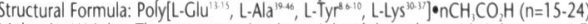

Molecular Weight: The average molecular weight of the polypeptide is between 4,700 and 11,000 daltons, with at least 68 percent of the material within the range of 2,500 to 22,500 daltons.

Physical Form: White to slightly yellowish lyophilized material.

pH: $\quad$ Sparingly soluble in water, insoluble in acetone.

Composition: COPAXONE ${ }^{B}$ (glatiramer acetate for iniection) is a sterile, lyophilized drug product, intended for subcutaneous injection following reconstitution with Sterile Water for Injection. Each vial of lyophilized drug product contains $20 \mathrm{mg}$ glatiramer acetate, plus a $2 \mathrm{mg}$ overage to allow for losses in reconstitution and transter, and $40 \mathrm{mg}$ mannitol. Each vial of Sterile Water for Injection contains $1.1 \mathrm{~mL}$ of Sterile Water for Injection plus a $0.35 \mathrm{~mL}$ overage to allow for losses in reconstitution and transter.

COPAXONE⿱ (glatiramer acetate iniection) is a single-use $20 \mathrm{mg} / 1.0 \mathrm{~mL}$ pre-filled syringe containing a stenile solution equivalent with the COPAXONE" reconstituted solution (i.e., $20 \mathrm{mg} / \mathrm{mL}$ glatiramer acetate and $40 \mathrm{mg}$ mannitol in sterile water for injection). Stability and Storage Recommendations: Vials of lyophilized COPAXONEE" should be stored under refrigeration $\left(2^{\circ}-8^{\circ} \mathrm{C}\right)$.
COPAXONE" may also be stored at room temperature $\left(15^{\circ}-30^{\circ} \mathrm{C}\right)$ for up to 14 days. The vials of diluent (Sterile Water for Iniection) should be stored at room temperature.

The pre-filled syringes of COPAXONE" should be refrigerated immediately upon receipt (between $2^{\circ}-8^{\circ} \mathrm{C}$ ). DO NOT FREEZE. If you cannot have refrigerator storage, pre-filled syringes of COPAXONE" can be stored at room temperature $\left(15^{\circ} .30^{\circ} \mathrm{C}\right)$ for up to one week. Do not store pre-filled syringes at room temperature for longer than one week. Note: this drug is light sensitive, do not expose to light when not injecting. Each pre-filled syringe is for single use only.

Reconstituted Solutions: To reconstitute lyophilized COPAXONE" prior to injection, use a sterile syringe and adapter to transfer the diluent supplied, Sterile Water for Injection, into the COPAXONE" vial. Gently swirl the vial of COPAXONE" and let stand at room temperature until the solid material is completely dissolved. Inspect the reconstituted product visually and discard or return the product to the pharmacist if it contains particulate matter. Soon after the product is completely dissolved, withdraw $1.0 \mathrm{~mL}$ of the solution into a sterile syringe. Remove the adapter, connect a 27 -gauge needle and inject the solution subcutaneously. A vial is suitable for single use only; unused portions should be discarded. The reconstituted solution should not be left longer than 8 hours at room temperature.

Parenteral Products: COPAXONE" should be reconstituted only with the provided diluent, Sterile Water for Injection.

\begin{tabular}{|c|c|c|c|}
\hline Vial Size & $\begin{array}{c}\text { Volume of Diluent } \\
\text { to be Added }\end{array}$ & $\begin{array}{c}\text { Volume to be } \\
\text { Injected }\end{array}$ & $\begin{array}{c}\text { Nominal } \\
\text { Concentration per } \mathrm{mL}\end{array}$ \\
\hline $2 \mathrm{~mL}$ & $1.1 \mathrm{~mL}$ & $1.0 \mathrm{~mL}$ & $20 \mathrm{mg}$ \\
\hline
\end{tabular}

\section{AVAILABILITY OF DOSACE FORMS}

COPAXONE (glatiramer acetate for injection) is supplied as a $20 \mathrm{mg}$ dose of sterile lyophilized glatiramer acetate with mannitol, packaged in single use $2 \mathrm{~mL}$ amber vials. A separate vial, containing $1.1 \mathrm{~mL}$ of diluent (Sterile Water for Injection) plus $0.35 \mathrm{~mL}$ of overage of diluent is included in the Seff Iniection Administration Package for each vial of drug COPAXONE: glatiramer acetate for iniection) is available in packs of 32 amber vials of sterile lyophilized material for subcutaneous injection. The diluent (Sterile Water for Injection) for COPAXONE" is supplied in packs of 32 clear vials and is located in the Self Injection Administration Package.

COPAXONE" (glatiramer acetate injection) is a single-use $20 \mathrm{mg} / 1.0 \mathrm{~mL}$ pre-filled syringe containing a sterile solution equivalent with the COPAXONEs reconstituted solution (i.e, $20 \mathrm{mg} / \mathrm{mL}$ latiramer acetate and $40 \mathrm{mg}$ mannitol in sterile water for injection). COPAXONE' (glatiramer acetate injection) is available in packs of 30 single-use $20 \mathrm{mg} / 1.0 \mathrm{~mL}$ pre-filled glass syringes with 33 alcohol preps (swabs).

\section{REFERENCE}

1. COPAXONE* (glatiramer acetate) Product Monograph, Teva Neuroscience.

Product monograph available upon request.

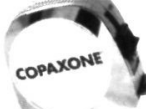
2003 


\section{COPAXONE (acetala de glatiramère inectable)}

$20 \mathrm{mg}$, flacons unidoses et $20 \mathrm{mg} / 1,0 \mathrm{~mL}$, seringues préremplies pour injection sous-cutanée CLASSIFICATION THÉRAPEUTIQUE Immunomodulateur

ACTION ET PHARMACOLOGIE CLINIQUE

COPAXONE [acétate de glatiramère pour injection (connu auparavant sous le nom de copolymère1)] es I'acide $L$-glutamique, la $L$-alanine, la $L$-tyrosine et la $L$-lysine dans une fraction molaire moyenne de 0,141 de 0,427 , de 0,095 et de 0,338 , respectivement. complètement élucidé. On croit cependant que l'acétate de glatiramère exercerait un effet modulateur sur les processus immuns que l'on associe actuellement à la pathogenèse de la SEP. Cette hypothèse est étayée par les résultats des essais menés pour explorer la pathogenese de l'encéphalomyélite allergique expérimentale (EAE), affection qui peut être déclenchée chez plusieurs espèces animales et qui est généralement acceptée comme modèle expérimental de la SEP.

Les études expérimentales sur animaux et les systèmes in vitro laissent supposer que l'administration de l'acétate de glatiramère induit et active des lymphocytes T suppresseurs spécifiques dans le sang périphérique. possible que le produit puisse avoir des effets sur les réactions immunitaires naturelles (voir PRÉCAUTIONS). Pharmacocinétique : Les résultats obtenus au cours des essais pharmacocinétiques menés chez les humains (volontaires sains) et les animaux étayent l'hypothèse selon laquelle une fraction importante de la dose thérapeutique délivrée au patient par voie sous-cutanée est hydrolysée localement. Neanmoins, de grands thérapeutique délivrée au patient par voie sous-cutanée est hydrolysée localement. Neanmoins, de grands
fragments d'acétate de glatiramere peuvent être reconnus par les anticorps réactifs contre l'acétate de glatiramère. Une certaine proportion de la dose injectée, intacte ou partiellement hydrolysée, passerait glatiramère. Une certaine proportion de la dose injectée, intacte ou partiellement hydrolysée, passerait régionaux; de plus, il est possible qu'une partie du produit intact passe dans la circulation générale. Essais cliniques: L'efficacité de COPAXONE* (acétate de glatiramere pour injection) a été évaluée dans le cadre de deux essais comparatifs (avec placebo) chez des patients atteints de SEP rémittente. Un troisième cadre de deux essais comparatifs (avec placebo) chez des patients atteints de SEP rémittente. Un troisième ces essais, on a eu recours à une dose de $20 \mathrm{mg} /$ /jour. Aucune autre dose ou schéma posologique n'ont été étudiés dans des essais comparatifs (avec placebo) sur la SEP rémittente.

Le premier essai Essai I (Essai BR-1) était un essai pilote comparatif (avec placebo) à répartition aléatoire en paires appariées, à groupes parallèles et à double insu qui a été mené dans un seul centre ${ }^{15}$. Cinquante

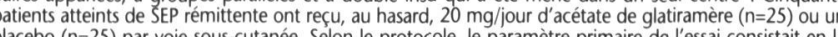

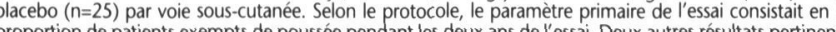
ont également servi de paramètres dansée pendant les deux ans de l'essai. Deux autres résultats pertinents la variation de la fréquence des poussées par comparaison à la fréquence des poussées pendant les deux années précédant l'entrée à l'essai. Les résultats de cet essai (tableau 1) démontrent que l'acétate de glatiramere exercait un effet statistiquement significatif sur le nombre de poussées.

TABLEAU 1 - Essai BR-1 : résultats quant à l'efficacité

\begin{tabular}{|l|c|c|c|}
\hline \multicolumn{1}{|c|}{ Résultats } & \multicolumn{3}{c|}{ Essai I } \\
\hline & $\begin{array}{c}\text { Acétate de glatiramère } \\
\mathbf{n = 2 5}\end{array}$ & $\begin{array}{c}\text { Placebo } \\
\mathbf{n = 2 5}\end{array}$ & Valeur de $\boldsymbol{p}$ \\
\hline$\%$ de patients exempts de poussée & $14 / 25(56 \%)$ & $7 / 25(28 \%)$ & 0,085 \\
\hline Fréquence moyenne des poussées & $0,6 / 2$ ans & $2,4 / 2$ ans & 0,005 \\
\hline $\begin{array}{l}\text { Réduction de la fréquence des poussées } \\
\text { comparativement aux donnees avant l'essai }\end{array}$ & 3,2 & 1,6 & 0,025 \\
\hline Délai médian avant la première poussée (jours) & $>700$ & 150 & 0,03 \\
\hline$\%$ de patients exempts de progression* & $20 / 25(80 \%)$ & $13 / 25(52 \%)$ & 0,07 \\
\hline
\end{tabular}

Le paramètre primaire de l'efficacité de l'Essai I consistait en la proportion de patients exempts $d$ poussée pendant les deux ans de l'essai (\% de patients exempts de poussée). Les analyses portaient sur l'ensemble des sujets retenus au début de l'essai.

La progression se définissait comme une augment
persistant pendant au moins trois mois consécutifs.

L'Essai II (01-9001) était un essai comparatif (avec placebo), multicentrique, à double insu et à répartition aléatoire. Deux cent cinquante et un patients atteints de SEP rémittente ont reçu, au hasard, $20 \mathrm{mg} / \mathrm{jou}$ d'acétate de glatiramère $n=125$ ) ou un placebo $(n=126)$ par voie sous-cutanee ${ }^{\prime}$. Les patients avaient fait
l'objet d'un diagnostic de SEP rémittente selon les criteres standards et avaient subi au moins deux poussées pendant les deux années précédant immédiatement l'entrée à l'essai. Les patients devaient présenter une cote maximale de 5 sur l'échelle élargie de l'état d'invalidité de Kurtzke (EDSS, Expanded présenter une cote maximale de 5 sur l'échelle élargie de l'état d'invalidité de Kurtzke (EDSS, Expanded
Disability Status Scale), échelle standard de 0 (état normal) à 10 (décès secondaire à la SEP). Une cote de 5 définit un patient ambulatoire qui a des difficultés à vaquer à toutes ses activités habituelles en raison d'une invalidité ; une cote de 6 définit un patient ambulatoire qui a besoin d'aide pour vaquer à ses d'une invalidité ; une cote de 6 définit un patient ambulatoire qui a besoin d'aide pour

Les patients ont été examinés tous les trois mois pendant deux ans ainsi que dans les quelques jours Les patients ont ete examines tous les trois mois pendant deux ans ainsi que dans les quelques jours suivant une poussée possible. Toute poussée devait être confirmée par un neurologue qui ignorait le
traitement reçu et qui devait noter la présence de signes neurologiques objectifs ainsi que d'autres critères (p. ex., la persistance de la lésion pendant au moins 48 heures).

Le protocole précisait que le paramètre primaire de l'essai était le nombre moyen de poussées pendant le traitement.

Le tableau 2 présente les résultats de l'analyse du paramètre primaire et de plusieurs paramètres secondaires de l'Essai II à deux ans, analyse portant sur l'ensemble des sujets retenus au début de l'essai.

\begin{tabular}{|l|c|c|c|}
\hline \multicolumn{2}{|c|}{ Résultats } & \multicolumn{3}{c|}{ Essai II } \\
\hline & $\begin{array}{c}\text { Acétate de glatiramère } \\
\mathbf{n = 1 2 5}\end{array}$ & $\begin{array}{c}\text { Placebo } \\
\mathbf{n = 1 2 6}\end{array}$ & Valeur de $\boldsymbol{p}$ \\
\hline Nombre moyen de poussées (2 ans) & 1,19 & 1,68 & 0,055 \\
\hline \% de patients exempts de poussée & $42 / 125(34 \%)$ & $34 / 126(27 \%)$ & 0,25 \\
\hline Délai médian avant la première poussée (jours) & 287 & 198 & 0,23 \\
\hline \% de patients exempts de progression & $98 / 125(78 \%)$ & $95 / 126(75 \%)$ & 0,48 \\
\hline Variation moyenne de la cote EDSS & $-0,05$ & $+0,21$ & 0,023 \\
\hline
\end{tabular}

'Le paramètre primaire de l'efficacité de l'Essai II était le nombre de poussé
Les analyses portaient sur l'ensemble des sujets retenus au début de l'essai.

Les analyses portaient sur l'enser
'Moyenne ajustée de départ

'La progression se définissait comme une augme

Les effets de l'acétate de glatiramère sur la gravité des poussées n'ont pas été évalués dans ces deux essais. Les deux essais ont révélé que l'acétate de glatiramère avait un effet bénéfique sur la fréquence des poussées; on considère donc que l'acétate de glatiramère est un produit efficace à cet égard. Le troisième essai (9003) était un essai multicentrique, multinational, avec surveillance IRM. Au total, 239 patients atteints de SEP rémittente (119 traités par l'acétate de glatiramère et 120 par un placebo) ont été répartis au hasard. Les critères d'inclusion étaient similaires à ceux de l'Essai II (Essai 01-9001) avec en plus le critere selon lequel les patients devaient présenter au moins une lésion rehaussée par le Cd a lexamen IRM subi des examens IRM mensuels. Le paramètre primaire de la phase à double insu était le nombre cumulatif total de lésions rehaussées par le Gd en pondération T1 pendant les neuf mois. D'autres paramètres IRM ont été évalués à titre de paramètres secondaires. Le tableau 3 résume les résultats obtenus pour les paramètres surveillés pendant la phase à double insu de neuf mois pour l'ensemble des sujets retenus au début de discussion, on ignore la valeur pronostique des résultats statistiquement significatifs suivants.
TABLEAU 3 - Phase à double insu de neuf mois : paramètres IRM - résultats

\begin{tabular}{|c|c|c|c|c|}
\hline $\mathbf{N}^{\circ}$ & Résultats & $\begin{array}{c}\text { Acétate de } \\
\text { glatiramère } n=113\end{array}$ & $\begin{array}{c}\begin{array}{c}\text { Placebo } \\
\mathrm{n}=115\end{array} \\
\end{array}$ & $\begin{array}{l}\text { Valeur } \\
\text { de } p\end{array}$ \\
\hline \multicolumn{5}{|c|}{ Paramètre primaire } \\
\hline 1. & $\begin{array}{l}\text { Médianes du nombre cumulatif de lésions } \\
\text { rehaussées par le Gd en T1 }\end{array}$ & 12 & 17 & 0,0037 \\
\hline \multicolumn{5}{|c|}{ Paramètres secondaires } \\
\hline 2. & \begin{tabular}{|l} 
Médianes du nombre cumulatif de nouvelles \\
lésions rehaussées par le Gd en T1
\end{tabular} & 9 & 14 & 0,0347 \\
\hline 3. & Médianes du nombre cumulatif de nouvelles lésions en T2 & 5 & 8 & 0,01 \\
\hline 4. & $\begin{array}{l}\text { Médianes de la variation cumulative par rapport aux valeurs de } \\
\text { départ du volume (mL) des lésions rehaussées par le } \mathrm{Cd} \text { en } \mathrm{TI}\end{array}$ & $-0,309$ & 0 & 0,0248 \\
\hline 5. & $\begin{array}{l}\text { Médianes de la variation cumulative par rapport aux } \\
\text { valeurs de départ du volume }(\mathrm{mL}) \text { des lésions en } \mathrm{T2}\end{array}$ & 8,852 & 13,566 & 0,0229 \\
\hline 6. & $\begin{array}{l}\text { Médianes de la variation cumulative par rapport aux valeurs } \\
\text { de départ du volume (mL) des lésions hypo-intenses en } \mathrm{T} 1\end{array}$ & 1,642 & 1,829 & 0,7311 \\
\hline 7. & Proportion de patients exempts de lésion rehaussée par le Gd en T1 & $46,4 \%$ & $32,2 \%$ & 0,0653 \\
\hline
\end{tabular}

Le nombre moyen de poussées au cours de cet essai de neuf mois était de 0,50 pour le groupe COPAXONE et de 0,77 pour le groupe placebo $(p=0,0077)$.

utilisation chez les patients ambulatoires atteints de sclérose L'innocuí évalué

CONTRE-INDICATIONS COPAXONE (acétate de glatiramère pour injection) est contr
patients présentant une hypersensibilité avérée à l'acétate de glatiramère ou au mannitol. MISES EN GARDE La seule voie d'administration recommandée de COPAXONE ${ }^{\circ}$ (acétate de glatiramère pour injection) est la voie sous-cutanée. COPAXONE $E^{\circ}$ ne doit pas être administré par voie intraveineuse. Symptômes
qui risquent d'avoir une origine cardiaque : Environ $26 \%$ des patients qui ont reçu COPAXONE dans l'essai qui risquent d avoir une origine cardiaque : Environ $26 \%$ des patients qui ont reçu COPAXONE dans l'essai comparatif et multicentrique de précommercialisation (par comparaison à $10 \%$ des patients ayant reçu un placebo) ont, Subi au moins un épisode de ce qui a été décrit comme une douleur thoracique transitoire (voir
EFFETS INDESSIRABLES : Douleur thoracique). Seulement certains de ces épisodes sont survenus dans le cadre de la réaction apparaissant immédiatement après l'injection (voir EFFETS INDÉSIRABLES : Réaction suivant l'injection), Aucune surveillance de l'ECC n'a été réalisée pendant l'un de ces épisodes, et la pathogenèse de ce symptome demeure inconnue. Comme les patients des essais comparatifs ne presentaient pas de troubles
cardiovasculaires significatifs (classe I ou II selon la New York Heart Association), on ignore les risques que courent les patients qui souffrent d'une atteinte cardiovasculaire et qui reçoivent COPAXONE $E^{*}$ dans le traitement de

L'administration de COPAXONE* a été associée à une réaction suivant l'injection consistant en un ensemble de symptômes qui surviennent immédiatement après l'injection et qui peuvent comprendre les bouffées congestives, la douleur thoracique, les palpitations, l'anxiété,
(voir EFFETS INDÉSIRABLES: Réaction suivant I'injection).

COPAXONE ${ }^{\prime}$ 'a pas été étudié chez des sujets présentant des antécédents de réactions anaphylactoödes graves, de bronchopneumopathie chronique obstructive ou d'asthme ni chez des patients qui reçoivent des
médicaments dans le traitement de l'une de ces deux dernieres affections. II convient donc de faire preuve de prudence pour ce qui est de l'utilisation de COPAXONE ${ }^{\circ}$ chez ce type de patients.

De rares cas de réactions anaphylactoides $(<1 / 1000)$ ont été rapportés en association avec l'utilisation de COPAXONE au cours de la période de postcomm

PRÉCAUTIONS Générales : Les patients doivent connaître les techniques de reconstitution et d'auto-injection respectant l'asepsie de sorte que COPAXONE* (acétate de glatiramère pour injection) soit administré de façon sûre (voir INFORMATION Ä L'INTENTION DU PATIENT). La première injection doit être effectuée sous la supervision d'un professionnel de la sante qualifié. Il convient de verifier periodiquement si les patients comprennent et respectent les techniques d'auto-administration respectant l'asepsie. On doit avertir les patients de ne pas réudoivent jeter les aiguilles et les seringues utilisées dans un contenant non perforable. On doit en outre explique aux patients comment mettre au rebut les contenants non perforables une fois remplis.

Considérations en matière d'utilisation d'un produit capable de modifier les réactions immunitaires: COPAXONE" étant une substance antigénique, son utilisation risque de déterminer des réactions délétères pour I'hôte. On ignore en outre si COPAXONE* peut modifier les réactions immunitaires déteteres pour I'hôte. On ignore en outre si COPAXONE $E^{\circ}$ peut modifier les réactions immunitaires
normales de l'être humain, comme la reconnaissance des antigènes étrangers. II est donc possible que le normales de l'être humain, comme la reconnaissance des antigenes etrangers. Il est donc possible que le ainsi que les mécanismes de surveillance des tumeurs. Aucune évaluation systématique de ces risques n'a encore été entreprise. L'altération continue de l'immunité cellulaire due au traitement chronique avec l'acétate de glatiramère pourrait entraîner des effets indésirables.

Des anticorps réactifs contre l'acétate de glatiramère sont formés chez presque tous les patients exposés au traitement quotidien avec la dose recommandée. Selon des essais menés chez le rat et le singe, des complexes immuns SEP remittente qui ont reçu $20 \mathrm{mg}$ d'acétate de glatiramère pendant deux ans, les taux sériques d'lgC ont atteint SEP remittente qui ont reçu $20 \mathrm{mg}$ d'acétate de glatiramère pendant deux ans, les taux seriques d'IgC ont atteint
des taux au moins trois fois plus elevés que les taux de départ chez $80 \%$ des patients trois mois après le début du traitement. Après 12 mois de traitement, cependant, $30 \%$ des patients avaient toujours des taux d'lgG au moins trois fois plus élevés que les taux de départ et $90 \%$ avaient des taux plus élevés que les taux de départ après 12 mois. Les anticorps sont uniquement de sous-type lgG, et surtout de sous-type lgG-1. Aucun anticorps de
type lgE n'a été détecté chez aucun des 94 sérums testes. Néanmoins, compte tenu que l'anaphylaxie peut être type lgE n'a éte détecté chez aucun des 94 sérums testes. Néanmoins, compte tenu que l'anaphylaxie pro
associee à l'administration de presque toutes les substances étrangères, ce risque ne peut être exclu. Des essais précliniques visant à évaluer le potentiel carcinogène de l'acétate de glatiramère chez la souris et le rat n'ont fait ressortir aucun signe de potentiel carcinogène associé a l'administration sous-cutanée de l'acétate de glatiramère des doses allant jusqu'à $30 \mathrm{mg} / \mathrm{kg} /$ jour chez le rat et jusqu'à $60 \mathrm{mg} / \mathrm{kg} /$ jour chez la souris (Voir TOXICOLOCIE :
Potentiel carcinogène). On ignore si ces résultats sont extrapolables à l'humain (voir PRÉCAUTIONS : Considérations en matière d'utilisation d'un produit capable de modifier les réactions immunitaires).

en matiere d'utilisation d'un produit capable de modifier les reactions immunitaires). Interactions médicamenteuses : Les interactions médicamenteuses entre COPAXONE ${ }^{*}$ et d'autres produits
n'ont pas fait l'objet d'une évaluation complète. Les résultats des essais cliniques à ce jour ne font pas ressortir n'ont pas fait l'objet d'une évaluation complète. Les résultats des essais cliniques à ce jour ne font pas ressortir
d'interaction significative entre COPAXONE*' et les traitements habituels de la SEP, y compris l'administration concomitante de corticostéroides pendant un maximum de 28 jours. COPAXONE" n'a pas été évalué de façon formelle en association à l'interféron bêta. En revanche, 246 patients chez lesquels le traitement par l'interféron bêta a échoue ou qui n'ont pas toléré le traitement et qui ont été par la suite traites avec COPAXONE dans
cadre d'un essai clinique ouvert n'ont pas signalé l'apparition d'effets indésirables graves ou inattendus pouvant être liés au traitement.

Crossesse : Aucun essai comparatif rigoureux portant sur des femmes enceintes n'a été réalisé. Les essais précliniques n'ont pas fait ressortir de signe de toxicité liée à la reproduction (voir TOXICOLOCIE : Reproduction et tératologie). Etant donné que les essais de reproduction chez les animaux ne permettent pas toujours de
prévoir les effets d'un produit chez l'être humain, ce médicament ne doit être administré pendant la grossesse prevoir les effets d'un produit chez létre humain, ce médicament ne doit être administré pendant la grossesse
que si son utilité a été clairement établie. Dans le cadre des essais cliniques de précommercialisation portant sur que si son utilité a été clairement établie. Dans le cadre des essais cliniques de précommercialisation portant su femmes a été perdue de vue pendant le suivi ; trois femmes ont choisi d'interrompre leur grossesse, et les trois autres ont cessé de prendre le produit un mois, un mois et demi et deux mois après avoir découvert qu'elles étaient enceintes. Ces trois femmes ont donné naissance à des enfants en bonne san

Allaitement : On ignore si le produit passe dans le lait maternel. Étant donné qu'un grand nombre de médicaments passent effectivement dans le lait maternel, l'administration de $\mathrm{COPAXONE}^{8}$ à une femme qui
allaite ne doit être envisagee qu'après une évaluation soigneuse du rapport risques-avantages, et le produit doit Enfants: L'innocuité et l'.

Enfants : L'innocuité et l'efficacité de COPAXONE n'ont pas été établies chez les sujets de moins de 18 ans. Patients âgés: COPAXONE ${ }^{\circ}$ n'a fait l'objet d'aucune évaluation spécifique chez les personnes âgées
(plus de 65 ans).

Insuffisants rénaux : Les paramètres pharmacocinétiques de $\mathrm{COPAXONE}^{\circ}$ n'ont pas été déterminés chez les EFFETS INDÉs d'un dysfonctionnement rénal.

INESIRABLES Au cours des essais cliniques de précommercialisation, environ 900 personnes ont reçu au moins une dose de COPAXONE (acétate de glatiramère pour injection) dans le cadre d'essais cliniques comparatifs ou non. Lexposition totale des patients à COPAXONE ${ }^{8}$ au cours d'essais cliniques s'échelonne de six mois $(693$
patients) à deux ans ( 306 patients), et à plus de sept ans ( 69 patients) à raison d'une dose quotidienne de $20 \mathrm{mg}$. Au cours des essais comparatifs, les effets indésirables le plus fréquemment associés à l'utilisation de COPAXONE et dont l'incidence était supérieure à celle qui a été observée chez les sujets qui recevaient le placebo étaient les 
arthralgie, anxiété et hypertonie.

Sur un total de 844 patients qui pouvaient faire l'objet d'une évaluation de l'innocuité du produit, environ $8 \%$ des sujets ont abandonne le traitement en raison d'effets indésirables. Les effets indésirables le plus fréquemment associés a labandon du traitement étaient les suivants : réactions au point d'injection (6,5\%), vasodilatation, grossesse ndésirables graves an, dyspnee, urticaire, tachycardie, etourdissements et tremblement. Au nombre des liés l'administration de COPAXONE", on compte un cas de maladie du sérum ayant menacé la survie du patient Re COPAXONE" dans le cadre des essais précedant la commercialisation du produit ont signale une reaction apparaissant inmedialement apres linjection sous-cutanée de COPAXONE. Les symptomes ressentis pouvaient comprendre les bouffées congestives, la douleur thoracique, les palpitations, l'anxiété, la dyspnée, la constriction de la gorge e l'urticaire. Ces symptômes étaient toujours transitoires et spontanement résolutifs et n'exigeaient pas de traitemen particulier. Ils survenaient en général plusieurs mois après l'etablissement du traitement et parfois plus tôt. Un patien particulier pouvait subir un seul ou plusieurs de ces épisodes pendant son traitement par COPAXONË. On ne sait pas si ces épisodes sont liés à des mécanismes immunologiques ou non, ni si plusieurs épisodes semblables survenant che un même patient relèvent de mécanismes identiques. En fait, on ignore si cet ensemble de symptômes représente véritablement un syndrome spécifique. Au cours de la période de postcommercialisation, des pa
subi des symptômes similaires et recu des soins médicaux d'urgence (voir MISES EN C'ARDE).

subi des symptômes similaires et reçu des soins médicaux d'urgence (voir MISES EN GARDE). Douleur thoracique : Environ $26 \%$ des patients qui ont reçu de l'acétate de glatiramère dans l'essai comparat multicentrique de précommercialisation (par comparaison à $10 \%$ des patients ayant reçu un placebo) ont subi a noins un episode de ce qui a ete decrit comme une douleur thoracique transitoire. Seulement certains de ces paragraphe précent Le lien temporel entre la douleur thoracique et l'iniection d'acétate de glatinamere n'étit pas paragraphe precedent. Le nétit transitoire (elle eu duat ha el souvent seule et ne semblait pas laisser d'importantes séquelles cliniques. Aucune surveillance de l' I'ECC $n^{\prime}$ a éte réalisée pendant l'un de ces épisodes. Certains patients ont subi plus d'un épisode de douleur thoracique, et épisodes commencaient à apparaitre. Certains patients ont subi plus dun épisode de douleur thoracique, et ces episodes commençaient a apparaitre, en régle generale, au moins un mois apres l'etablissement du traitement. La un ECG complet a été effectué; l'ECG n'a révélé aucun signe d'ischémie. Comme les patients des essais cliniques ne présentaient pas de troubles cardiovasculaires significatiff (classe I ou II selon la New York Heart Association), on ignore les risques que courent les patients qui souffrent d'une atteinte cardiovasculaire et qui reçoivent l'acétate de glatiramère dans le traitem

e tableau 4 dresse la liste des effets indésirables observés après un maximum de 35 mois de traitement (plus de 27 mois 33 mois : COPAXONE*,$n=84$; placebo, $n=75$; plus de 33 mois : COPAXONE,$n=12$; placebo, $n=24$ ) dans le cadre de l'Essai II (essai comparatif [avec placebo] multicentrique de precommercialisation portant sur des patients atteints de sclérose en plaques remittente) et dont l'incidence était d'au moins $2 \%$ parmi les sujets qui recevaient COPAXONE" d'au moins $2 \%$ de plus que l'incidence observée parmi les sujets du même essai qui recevaient le placebo, peu importe le lien de cause à effet entre la réaction et le traitement. Aucun résultat des épreuves de laboratoire répondant à ces critères n'a été signalế.

II est à noter que les données du tableau 4 ne peuvent pas servir à prévoir lincidence des effets indésirables du traitement dans le cadre de l'exercice normal de la médecine, étant donné que les caractéristiques des patients ainsi que dautres lacteursisquent de ne pas être les mêmes que ceux des essais ciniques. Ces données foumissent tout de même et non liés au médicament en ce qui a trait à l'incidence des effets indésirables dans la population étudiée.

TABLEAU 4

Essai comparatif de précommercialisation chez des patients atteints de SEP

\begin{tabular}{|c|c|c|c|c|}
\hline \multirow[b]{2}{*}{ Effets indésirables } & \multicolumn{2}{|c|}{$\begin{array}{c}\text { COPAXONE" } \\
n=125\end{array}$} & \multicolumn{2}{|c|}{$\begin{array}{c}\begin{array}{c}\text { Placebo } \\
\mathrm{n}=126\end{array} \\
\end{array}$} \\
\hline & $\mathrm{n}$ & $\%$ & $\mathrm{n}$ & $\%$ \\
\hline $\begin{array}{l}\text { Organisme dans son ensemble } \\
\text { Douleur au point d'injection } \\
\text { Asthénie } \\
\text { Erytheme au point d'injection } \\
\text { Prurit au point d'injection } \\
\text { Syndrome pseudo-grippal } \\
\text { Inflammation au point d'injection } \\
\text { Douleur dorsale } \\
\text { Douleur thoracique } \\
\text { Masse au point d'injection } \\
\text { Induration au point d'injection } \\
\text { Papule au point d'injection } \\
\text { Douleur au cou } \\
\text { Edème du visage } \\
\text { Urticaire au point d'injection } \\
\text { Hémorragie au point d'injection } \\
\text { Frissons } \\
\text { Kyste } \\
\text { Réaction au point d'injection } \\
\text { Atrophie au point d'injection } \\
\text { Abcés }\end{array}$ & $\begin{array}{l}83 \\
81 \\
73 \\
48 \\
38 \\
35 \\
33 \\
33 \\
33 \\
25 \\
19 \\
16 \\
11 \\
9 \\
8 \\
5 \\
5 \\
4 \\
3 \\
3 \\
\end{array}$ & $\begin{array}{l}66,4 \\
64,8 \\
58,4 \\
38,4 \\
30,4 \\
28,0 \\
26,4 \\
26,4 \\
26,4 \\
20,0 \\
15,2 \\
12,8 \\
8,8 \\
7,2 \\
6,4 \\
4,0 \\
4,0 \\
3,2 \\
2,4 \\
2,4\end{array}$ & $\begin{array}{c}46 \\
78 \\
17 \\
5 \\
34 \\
9 \\
28 \\
13 \\
10 \\
1 \\
5 \\
9 \\
2 \\
0 \\
4 \\
1 \\
1 \\
1 \\
0 \\
0\end{array}$ & $\begin{array}{c}36,5 \\
61,9 \\
13,5 \\
4,0 \\
27,0 \\
7,1 \\
22,2 \\
10,3 \\
7,9 \\
0,8 \\
4,0 \\
7,1 \\
1,6 \\
0 \\
3,2 \\
0,8 \\
0,8 \\
0,8 \\
0 \\
0\end{array}$ \\
\hline $\begin{array}{l}\text { Appareil cardiovasculaire } \\
\text { Vasodilatation } \\
\text { Palpitations } \\
\text { Migraine } \\
\text { Syncope }\end{array}$ & $\begin{array}{c}34 \\
14 \\
9 \\
8 \\
\end{array}$ & $\begin{array}{l}27,2 \\
11,2 \\
7,2 \\
6,4\end{array}$ & $\begin{array}{l}14 \\
6 \\
5 \\
4 \\
\end{array}$ & $\begin{array}{r}11,1 \\
4,8 \\
4,0 \\
3,2\end{array}$ \\
\hline $\begin{array}{l}\text { Appareil digestif } \\
\text { Nausées } \\
\text { Vomissements } \\
\text { Anorexie } \\
\text { Castro-entérite } \\
\text { Candidose orale } \\
\text { Carie dentaire } \\
\end{array}$ & $\begin{array}{c}29 \\
13 \\
6 \\
6 \\
3 \\
3\end{array}$ & $\begin{array}{r}23,2 \\
10,4 \\
4,8 \\
4,8 \\
2,4 \\
2,4\end{array}$ & $\begin{array}{l}22 \\
7 \\
3 \\
2 \\
0 \\
0\end{array}$ & $\begin{array}{c}17,5 \\
5,6 \\
2,4 \\
1,6 \\
0 \\
0\end{array}$ \\
\hline $\begin{array}{l}\text { Systèmes hématopoiétique et lymphatique } \\
\text { Adénopathie } \\
\text { Ecchymose }\end{array}$ & $\begin{array}{l}23 \\
15 \\
\end{array}$ & $\begin{array}{l}18,4 \\
12,0\end{array}$ & $\begin{array}{l}12 \\
12\end{array}$ & $\begin{array}{l}9,5 \\
9,5\end{array}$ \\
\hline $\begin{array}{l}\text { Troubles métaboliques et nutritionnels } \\
\text { GEdème périphérique } \\
\text { Gain pondéral } \\
\text { GEdème }\end{array}$ & $\begin{array}{l}14 \\
7 \\
5\end{array}$ & $\begin{array}{l}11,2 \\
5,6 \\
4,0\end{array}$ & $\begin{array}{l}7 \\
0 \\
1\end{array}$ & $\begin{array}{c}5,6 \\
0 \\
0,8\end{array}$ \\
\hline $\begin{array}{l}\text { Appareil musculosquelettique } \\
\text { Arthralgie }\end{array}$ & 31 & 24,8 & 22 & 17,5 \\
\hline $\begin{array}{l}\text { Système nerveux } \\
\text { Hypertonie } \\
\text { Tremblement } \\
\text { Agitation } \\
\text { Confusion } \\
\text { Nystagmus } \\
\end{array}$ & $\begin{array}{l}44 \\
14 \\
7 \\
5 \\
5\end{array}$ & $\begin{array}{l}35,2 \\
11,2 \\
5,6 \\
4,0 \\
4,0\end{array}$ & $\begin{array}{l}37 \\
7 \\
4 \\
1 \\
2\end{array}$ & $\begin{array}{l}29,4 \\
5,6 \\
3,2 \\
0,8 \\
1,6\end{array}$ \\
\hline $\begin{array}{l}\text { Appareil respiratoire } \\
\text { Rhinite } \\
\text { Dyspnée } \\
\text { Bronchite }\end{array}$ & $\begin{array}{l}29 \\
23 \\
18\end{array}$ & $\begin{array}{l}23,2 \\
18,4 \\
14,4\end{array}$ & $\begin{array}{c}26 \\
8 \\
12\end{array}$ & $\begin{array}{l}20,6 \\
6,4 \\
9,5\end{array}$ \\
\hline $\begin{array}{l}\text { Peau et annexes cutanées } \\
\text { Hypersudation } \\
\text { Erythème } \\
\text { Troubles dermatologiques } \\
\text { Nodule cutané } \\
\text { Verrue } \\
\end{array}$ & $\begin{array}{l}15 \\
8 \\
5 \\
4 \\
3\end{array}$ & $\begin{array}{l}12,0 \\
6,4 \\
4,0 \\
3,2 \\
2,4\end{array}$ & $\begin{array}{l}10 \\
4 \\
2 \\
1 \\
0\end{array}$ & $\begin{array}{l}7,9 \\
3,2 \\
1,6 \\
0,8 \\
0\end{array}$ \\
\hline $\begin{array}{l}\text { Organes des sens } \\
\text { Douleur auriculaire } \\
\text { Troubles oculaires } \\
\end{array}$ & $\begin{array}{l}15 \\
8 \\
\end{array}$ & $\begin{array}{c}12,0 \\
6,4 \\
\end{array}$ & $\begin{array}{c}12 \\
1\end{array}$ & $\begin{array}{l}9,5 \\
0,8\end{array}$ \\
\hline $\begin{array}{l}\text { Voies urogénitales } \\
\text { Miction impérieuse } \\
\text { Candidose vaginale } \\
\text { Dysménorrhée } \\
\text { Crossesse accidentelle } \\
\text { Impuissance }\end{array}$ & $\begin{array}{l}20 \\
16 \\
12 \\
4 \\
3\end{array}$ & $\begin{array}{l}16,0 \\
12,8 \\
9,6 \\
3,2 \\
2,4\end{array}$ & $\begin{array}{l}17 \\
9 \\
9 \\
0 \\
0\end{array}$ & $\begin{array}{c}13,5 \\
7,1 \\
7,1 \\
0 \\
0\end{array}$ \\
\hline
\end{tabular}

Voici les autres effets qui sont survenus chez au moins $2 \%$ des patients mais dont l'incidence dans le groupe placebo etait equivalente ou superieure:

Drganisme dans son ensemble : Cephalees, ecchymose au point d'injection, blessure accidentelle, douleur appominale, rhinite allergique et malaise.

Apparell digestif : Dyspepsie, constipation, dysphagie, incontinence fécale, flatulence, nausées et vomissements, gastrite, gingivite, abces periodontique et secheresse de la bouche.

systemen musculosquelettique: Myasthénie et myalgie. la coordination, somnolence, troubles de la démarche, amnésie, instabilité émotionnelle, signe de Lhermitte, anomalies de la pensée, secousses musculaires, euphorie et troubles du sommeil.

Appareil respiratoire : Pharyngite, sinusite, aggravation de la toux et laryngite.

Peau et annexes cutanées: Acné, alopécie et troubles des ongles.

Organes des sens : Anomalies de la vision, diplopie, amblyopie, douleur oculaire, conjonctivite, acouphènes, dysgueusie et surdité.

Voies urogenitales: Infection des voies urinaires, augmentation de la fréquence des mictions, incontinence Urinaire, retention urinaire, dysurie, cystite, métrorragie, douleur mammaire et vaginite.

es données portant sur les effets indésirables qui sont apparus au cours d'essais cliniques comparatifs ont éte analyseees dans l'optique d'évaluer les différences entre les sexes. Or, aucune différence cliniquement significative n'a été relevée. Dans ces essais cliniques, $92 \%$ des patients étaient de race blanche, ce qui est représentatif de la population de patients atteints de sclérose en plaques. De plus, la vaste majorité des patients traités par une analyse de l'incidence des effets indésirables en fonction de groupes d' trapge cliniquement pertinents.

Tous les patients ayant pris part aux essais cliniques sur COPAXONE ${ }^{\circ}$ ont subi des analyses de laboratoire. Les variations des paramètres de laboratoire (hématologie, biochimie sanguine et analyse des urines) qui étaient significatives sur le plan clinique étaient comparables entre les patients du groupe COPAXONE" et ceux du groupe placebo, dans le cadre des essais cliniques à l'insu. Aucun patient ayant reçu COPAXONE" ne s'est retire d'un essai en raison d'une anomalie des résultats des épreuves de laboratoire.

Autres effets indésirables observés durant tous les essais cliniques

COPAXONE a été administré à environ 900 personnes dans l'ensemble des essais cliniques, dont seulement certains etaient comparatifs (avec placebo). Au cours de ces essais, tous les effets indésirables ont été enregistrés par les chercheurs cliniques à l'aide de leur propre terminologie. De façon à donner une estimation efficace de la proportion des patients qui ont subi des effets indésirables, les effets semblables ont été regroupés en un plus petit nombre de catégories normalisées faisant appel à la terminologie du dictionnaire COSTART II. Tous les effets signalés qui sont survenus à au moins deux reprises ainni que les effets potentiellement graves qui sont survenus effets dont le caractère trop général ne procurait aucune information, les effets sans importance et les autres effets qui se sont manifestés chez au moins $2 \%$ des patients traités et qui étaient présents à une fréquence égale ou plus grande que dans le groupe placebo.

Les effets indésirables ont éte de plus classés en fonction des systèmes ou des appareils et énumérés en ordre décroissant de fréquence selon les définitions suivantes : les effets indésirables fréquents sont ceux qui sont survenus chez au moins un patient sur $100(1 / 100)$, tandis que les effets indésirables peu fréquents sont ceu qui sont survenus dans une proportion de un patient sur $100(1 / 100)$ à un patient sur $1000(1 / 1000)$. Organisme dans son ensemble : Fréquents : CEdème au point d'injection, atrophie au point d'injection, abcès et hypersensibilité au point d'injection.

Peu fréquents : Hématome au point d'injection, fibrose au point d'injection, faciès lunaire, cellulite, œedème genéralisé, hernie, abces au point d'injection, maladie du sérum, tentative de suicide, hypertrophie au poin d'injection, mélanose au point d'injection, lipome et réaction de photosensibilité.

Appareil cardiovasculaire : Frequent . Hypertension. Peu fréquents: Hypotension, claquement systolique, souffle systolique, fibrillation auriculaire, bradycardie, apparition d'un quatrième bruit du cœur, hypotension orthostatique et varices.

Appareil digestif : Peu fréquents : Sécheresse de la bouche, stomatite, sensation de brûlure sur la langue cholécystite, colite, ulcère de l'œesophage, œesophagite, cancer gastro-intestinal, hémorragie gingivale, hépatomégalie, augmentation de l'appétit, méléna, ulcération de la bouche, troubles du pancréas, pancrẻatite, hémorragie rectale, ténesme, coloration anormale de la langue et ulcère duodénal.

Systeme endocrinien : Peu frequents: Goitre, hyperthyroidie et hypothyroidie.

Troubles gastro-intestinaux : Fréquents: Défecation impérieuse, candidose orale, hypertrophie des glandes salivaires, carie dentaire et stomatite ulcereuse.

Systèmes hematopoiétique et lymphatique : Peu fréquents : Leucopénie, anémie, cyanose, éosinophilie, hematemese, lymphoedeme, pancytopenie et splenomegalie.

Troubles métaboliques et nutritionnels : Peu frequents : Perte pondérale, intolérance à l'alcool, syndrome de Cushing, goutte, anomalies de la cicatrisation et xanthome.

Appareil musculosquelettique : Peu frequents : Arthrite, atrophie musculaire, douleur osseuse, bursite, douleur rénale, troubles musculaires, myopathie, ostéomyélite, douleur tendineuse et ténosynovite.

Système nerveux : Frequents: Reves inhabituels, instabilite emotionnelle et stupeur. Peu frequents: Aphasie, ataxie, convulsion, paresthesie peribuccale, depersonnalisation, hallucinations, hostilite, hypocinesie, coma troubles de la concentration, paralysie faciale, diminution de la libido, réaction maniaque, troubles de la mémoire, myoclonie, névralgie, réaction paranoide, paraplégie, dépression psychotique et stupeur transitoire.
Appareil respiratoire : Fréquent : Hyperventilation, rhume des foins. Peu fréquents : Asthme, pneumonie, epistaxis, hypoventilation et modification de la voix,

Peau et annexes cutanees : Frequents: Eczema, zona, eruption pustuleuse, atrophie cutanee et verrues. Peu fréquents : Secheresse cutanée, hypertrophie cutanée, dermatite, furonculose, psoriasis, angio-øedème, eczema de contact, erytheme noueux, dermatite fongique, éruption maculopapuleuse, pigmentation, tumeur cutanée bénigne, cancer de la peau, vergetures et eruption vésiculobulleuse.

Organes des sens : Fréquents : Atteinte du champ visuel. Peu fréquents : Secheresse oculaire, otite externe, ptose, cataractes, ulcère de la cornee, mydriase, nevrite optique, photophobie et agueusie.

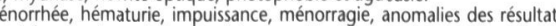
du test de Papanicolaou, pollakiurie et hémorragie vaginale. Peu fréquents : Vaginite, douleur au flanc (rein), avortement, engorgement mammaire, hypertrophie mammaire, douleur mammaire, cancer in situ du col de I'utérus, mastose sclérokystique, calcul rénal, nycturie, kyste ovarien, priapisme, pyélonéphrite, anomalies de la fonction sexuelle et uretrite.

Effets indésirables rapportés après la commencialisation et qui n'avaient pas déjà été notés lor des essais cliniques

'experience de postcommercialisation a dégagé un profil d'effets indesirables similaire à celui présenté cidessus. Après la mise sur le marché, on a signalé des effets indésirables, autres que celles indiquées ci-dessus, qui sont survenues pendant le traitement par COPAXONE" (acetate de glatiramere pour injection). Ces réac

Organisme dans son ensemble : Septicémie, syndrome lupoïde, hydrocéphalie, distension de l'abdomen, hypersensibilité au point d'injection, réaction allergique, réaction anaphylactoíde, infection bactérienne, Appareil cardiovasculaire : Thrombose, maladie vasculaire périphérique, épanchement péricardique, infarctus du myocarde, thrombophlébite extensive, occlusion coronarienne, insuffisance cardiaque congestive, car diomyopathie, cardiomegalie, arrythmie, angine de poitrine et tachycardie.

Appareil digestif : CFdéme de la langue, hémorragie gastrique d'origine ulcéreuse, altération de la fonction hepatique, atteinte hépatique, hépatite, éructation, cirrhose du foie, calculs biliaires, diarrhée et troubles

Systèmes hématopoiétique et lymphatique : Thrombocytopénie, réaction de type lymphome et leucémie aiguè

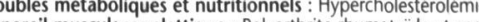

ppareil musculosquelettique : Polyarthrite rhumatoïde et spasme généralisé.

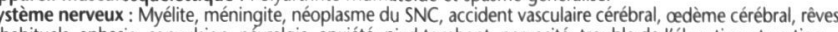
Appareil respiratoire : Embolie pulmonaire, épanchement pleural, cancer du poumon, rhume des foins Appareil respira

Peau et annexes cutanées : Herpès, prurit, éruption cutanée et urticaire.

Peau et annexes cutanees : Herpes, prurit, eruption cutanee et urtici
Organes des sens: Glaucome, cécité et atteinte du champ visuel.

Voies urogénitales: Néoplasme des voies urogénitales, anomalie urinaire, cancer des ovaires, néphrose, SURDOSAGE : SYMPTÓMES ET TRAITEMENT
SYUfisance rén

Des surdosages de COPAXONE* ont été signalés chez trois patients. Un patient s'est injecté quatre doses (soit un total de $80 \mathrm{mg}$ ) de COPAXONE' à la fois. Aucune sequelle n'a été notée. Deux autres patients, un (soit un total de $80 \mathrm{mg}$ ) de COPAXONE
homme de 28 ans et une femme de 37 ans, ont reçu, par erreur, trois injections de $20 \mathrm{mg}$ of COPAXONE' à des intervalles de une demi-heure. Aucun patient n'a manifesté de variation de sa pression artérielle, de sa fréquence cardiaque ni de sa température. Le suivi téléphonique effectué plusieurs heures plus tard n'a pas révélé d'effets indésirables dans un cas comme dans l'autre.
POSOLOGIE ET MODE D'ADMINISTRATION

La prescription de COPAXONE" doit être réservée aux médecins (ou après une consultation avec un médecin)

qui connaissent a fond le diagnostic et la prise en charge de la sclérose en plaques.
La dose recommandée de COPAXONE injectable) dans le traitement de la SEP rémittente est de une injection quotidienne de $20 \mathrm{mg}$ par voie sous-cutanée.

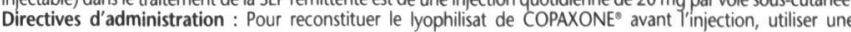




\section{power you can trust ${ }^{\mathrm{m}}$}

"LIPITOR*

(atorvastatin calcium)

$10 \mathrm{mg}, 20 \mathrm{mg}, 40 \mathrm{mg}$ and $80 \mathrm{mg}$ tablets

THERAPEUTIC CLASSIFCATION: Lipid Metabolism Regulator

\section{ACTIONS AND CLINICAL PHARMACOLOGY}

Please refer to the Product Monograph for complete ACTION and CLINICAL PHARMACOLOGY information.

Clinical Studies

\section{Prevention of Cardiovascular Disease}

In the Anglo-Scandinavian Cardiac Outcomes Trial (ASCOT), the effect of LIPITOR (atorvastatin calcium) on fatal and non-fatal coronary heart disease was assessed in 10,305 hypertensive patients 40-80 years of age (mean of 63 years), without a previous myocardial infarction and with TC levels $\leq 6.5 \mathrm{mmo} / \mathrm{L}$. Additionally all patients had at least 3 of the following cardiovascular risk factors: male gender $(81.1 \%)$, age $>55$ years $(84.5 \%)$, smoking $(33.2 \%)$, diabetes $(24.3 \%)$, history of CHD in a first-degree relative (26\%), TC:HDL $>6(14.3 \%)$, peripheral vascular disease $(5.1 \%)$, left ventricular hypertrophy $(14.4 \%)$, prior cerebrovascular event $(9.8 \%)$, specific ECG abnormality $(14.3 \%)$, proteinuria/albuminuria $(62.4 \%)$. In this double-blind, placebo-controlled study, patients were treated with anti-hypertensive therapy (Goal BP $<140 / 90 \mathrm{~mm} \mathrm{Hg}$ for non-diabetic patients, $<130 / 80 \mathrm{~mm} \mathrm{Hg}$ for diabetic patients) and allocated to either LIPTOR $10 \mathrm{mg}$ daily $(n=5168$ ) or placebo ( $n=5137$ ), using a covariate adaptive method which took into account the distribution of nine daily $(n=5168)$ or placebo ( $n=5137)$, using a covariate adaptive method which took into account the distribution of nine
baseline characteristics of patients already enrolled and minimized the imbalance of those characteristics across the groups. Patients were followed for a median duration of 3.3 years.

The effect of $10 \mathrm{mg} /$ day of LIPITOR on lipid levels was similar to that seen in previous clinical trials. LPITOR significantly reduced the rate of coronary events [either fatal coronary heart disease (46 events in the placebo group vs 40 events in the LPITOR group) or nonfatal MII (108 events in the placebo group vs 60 events in the LIPTOR group) with an absolute risk reduction of $11 \%$ and a relative risk reduction of $36 \%$ (based on incidences of $1.9 \%$ for UPITOR vs $3.0 \%$ for placebo), $\mathrm{p}=0.0005$ (see figure 1)]. This risk reduction vields a Number Needed to Treat of 311 patients per year. The risk reduction was consistent regardless of age, smoking status, obesity or presence of rena dysfunction. The effect of LIPITOR was seen regardless of baseline LDL levels. Due to the small number of events, results or women were inconclusive.

Figure 1: Effect of LIPITOR $10 \mathrm{mg} /$ day on Cumulative Incidence of Nonfatal Myocardial Infarction or Coronary Heart Disease Death (in ASCOT-LLA).

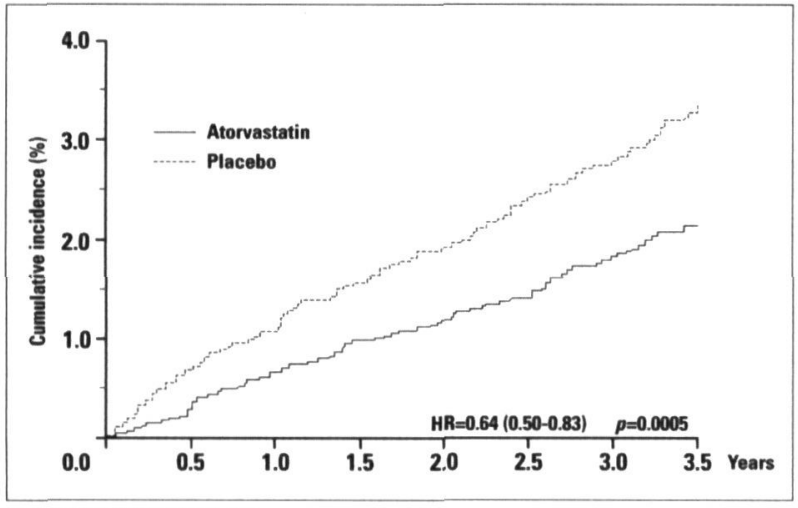

\section{INDICATIONS AND CLINICAL USE}

\section{Hypercholesterolemia}

LIPITOR (atorvastatin calcium) is indicated as an adjunct to lifestyle changes, including diet, (at least equivalen to the Adult Treatment Panel III (ATP III) TLC diet), for the reduction of elevated total cholesterol, (total-C), LDL-C TG and apolipoprotein B (apo B) in hyperlipidemic and dyslipidemic conditions, when response to diet and other nonpharmacological measures alone has been inadequate, including:

- Primary hypercholesterolemia (Type lla);

- Combined (mixed) hyperlipidemia (Type llb), including familial combined hyperlipidemia, regardless of whether cholesterol or triglycerides are the lipid abnormality of concern;

- Dysbetalipoproteinemia (Type III)

- Hypertriglyceridemia (Type IV)

- Familial hypercholesterolemia (homozygous and heterozygous). For homozygous familial hypercholesterolemia, LPITOR should be used as an adjunct to treatments such as LDL apheresis, or as monotherapy if such treatments are no available.

LIPTOR also raises HDL-cholesterol and therefore lowers the LDL-C/HDL-C and total-C/HDL-C ratios in patients with primary hypercholesterolemia and combined (mixed) hyperlipidemia (Fredrickson Type lla and llb dyslipidemia). In pooled data from 24 controlled clinical trials, LIPTOR raised HDL-C levels $5 \%-7 \%$ in primary hypercholesterolemic (type lla) patients and $10 \%-15 \%$ in mixed (type llb) dyslipidemic patients.

In clinical trials, LPITOR (10 to $80 \mathrm{mg} / \mathrm{day}$ ) significantly improved lipid profiles in patients with a wide variety of hyperlipidemic and dyslipidemic conditions. In 2 dose-response studies in mildly to moderately hyperlipidemic patients (Fredrickson Types lla and IIb), LIPITOR reduced the levels of total cholesterol $(29-45 \%)$, LDL-C $(39-60 \%)$, apo B (32-50\%), TG (19-37\%), and increased high density lipoprotein cholesterol (HDL-C) levels (5-9\%). Comparable responses were achieved in patients with heterozygous familial hypercholesterolemia, non-familial forms of hypercholesterolemia, combined hyperlipidemia, including familial combined hyperlipidemia and patients with non-insulin dependent diabetes mellitus. In patients with hypertriglyceridemia (Type IV), LIPITOR (10 to $80 \mathrm{mg}$ daily) reduced TG (25 - 56\%) and LDL-C levels (23 - 40\%). LPTTOR has not been studied in conditions where the major abnormality is elevation of chylomicrons ( $T \mathrm{G}$ levels $>11 \mathrm{mmol} / \mathrm{\text {) }}$. i.e., types I and V.

In an open-label study in patients with dysbetalipoproteinemia (Type III), LIPITOR (10 to $80 \mathrm{mg}$ daily) reduced total-C $(40-57 \%), T G(40-56 \%)$ and IDL-C + VLDL-C levels $(34-58 \%)$

In an open label study in patients with homozygous familial hypercholesterolemia (FH) LPITOR (10 to $80 \mathrm{mg}$ daily) reduced mean LDL-C levels (22\%). In a pilot study, LPPTOR $80 \mathrm{mg} /$ day showed a mean LDL-C lowering of $30 \%$ for patients not on plasmapheresis and of $31 \%$ for patients who continued plasmapheresis. A mean LDL-C lowering of $35 \%$ was observed in receptor defective patients and of $19 \%$ in receptor negative patients (see PHARMACOLOGY, Clinical Studies)

Prior to initiating therapy with LIPTOR, secondary causes should be excluded for elevations in plasma lipid levels (e.g. poorly controlled diabetes mellitus, hypothyroidism, nephrotic syndrome, dysproteinemias, obstructive liver disease, and alcoholism), and a lipid profile performed to measure total cholesterol, LDL C. HDL-C, and TG. For patients with TG $<4.52 \mathrm{mmol} /$ $(<400 \mathrm{mg} / \mathrm{dL}), \mathrm{LDL}-\mathrm{C}$ can be estimated using the following equation:

LDL $-\mathrm{C}(\mathrm{mmol} / \mathrm{L})=$ total $-\mathrm{C}-[(0.37 \times(\mathrm{TG})+\mathrm{HDL}-\mathrm{C})]$

DL $-\mathrm{C}(\mathrm{mg} / \mathrm{dL})=$ total- $\mathrm{C} \cdot[(0.2 \times(\mathrm{TG})+\mathrm{HDL}-\mathrm{C})]$

For patients with TG levels $>4.52 \mathrm{mmol} / \mathrm{L}(>400 \mathrm{mg} / \mathrm{dL}$ ), this equation is less accurate and LDL-C concentrations should be measured directly or by ultracentrifugation.
Patients with high or very high triglyceride levels, i.e. $>2.2 \mathrm{mmol} /(200 \mathrm{mg} / \mathrm{dL})$ or $>5.6 \mathrm{mmol} /(500 \mathrm{mg} / \mathrm{dL})$, respectively, may require triglyceride-lowering therapy (fenofibrate, bezafibrate or nicotinic acid) alone or in combination with LIPITOR.

In general, combination therapy with fibrates must be undertaken cautiously and only after risk-benefit analysis (see WARNINGS, Muscle Effects, PRECAUTIONS, Pharmacokinetic Interaction Studies and Potential Drug Interactions)

Elevated serum triglycerides are most often observed in patients with the metabolic syndrome labdominal obesity atherogenic dyslipidemia \{elevated triglycerides, small dense LDL particles and low HDL-cholesterol\}, insulin resistance with or without glucose intolerance, raised blood pressure and prothrombic and proinflammatory states)

(For the treatment of specific dyslipidemias refer to the Report of the Canadian Working Group on Hypercholesterolemia an Other Dyslipidemias or to the US NCEP Expert Panel on Detection, Evaluation, and Treatment of High Blood Cholesterol in Adults [Adult Treatment Panel III]).

When drugs are prescribed attention to therapeutic lifestyle changes (reduced intake of saturated fats and cholesterol, weight reduction, increased physical activity, ingestion of soluble fibers) should always be maintained and reinforced.

\section{Prevention of Cardiovascular Disease}

LPITOR is indicated to reduce the risk of myocardial infarction in adult hypertensive patients without clinically evident coronary heart disease, but with at least three additional risk factors for coronary heart disease such as age $\geq 55$ years, male sex, smoking, type 2 diabetes, left ventricular hypertrophy, other specified abnormalities on ECG, microalbuminuri or proteinuria, ratio of plasma total cholesterol to HDL-cholesterol $>6$, or premature family history of coronary heart disease. The Atorvastatin Versus Revascularization Treatments (AVERT) study examined the effect of intensive lipid-lowering in patients with stable coronary artery disease and LDL-C at least $3.0 \mathrm{mmol} / \mathrm{L}$ in patients referred for percutaneous translumina coronary angioplasty (PTCA). Patients were randomised for 18 months to LPITOR $80 \mathrm{mg}$ daily or to PTCA with usual medica care which could include lipid metabolism regulators. The results of the AVERT study should be considered as exploratory since several limitations may affect its design and conduct. In the medical-treated group with LIPITOR there was a trend for reduced incidence of ischemic events and a delayed time to first ischemic event. The results also suggest that intensive treatment to target LDL-C levels with LPITOR is additive and complementary to angioplasty and would benefit patients referred for this procedure.

\section{CONTRAINDICATIONS}

Hypersensitivity to any component of this medication.

Active liver disease or unexplained persistent elevations of serum transaminases exceeding 3 times the upper limit of norma (see WARNINGS).

Pregnancy and lactation (see PRECAUTIONS)

WARNINGS

Pharmacokinetic Interactions

The use of HMG-COA reductase inhibitors has been associated with severe myopathy, including rhabdomyolysis, which may be more frequent when they are co-administered with drugs that inhibit the cytochrome $\mathrm{P}-450$ enzyme system. Atorvastati S metabolized by cytochrome P-450 isoform 3A4 and as such may interact with agents that inhibit this enzyme. (See WARNINGS, Muscle effects and PRECAUTIONS. Drug Interactions and Cytochrome P-450-mediated Interactions).

Hepatic Effects

In clinical trials, persistent increases in serum transaminases greater than three times the upper limit of normal occurred n $<1 \%$ of patients who received LIPITOR. When the dosage of LIPITOR was reduced, or when drug treatment wa interrupted or discontinued, serum transaminase levels returned to pretreatment levels. The increases were generally not associated with jaundice or other clinical signs or symptoms. Most patients continued treatment with a reduced dose of LIPITOR without clinical sequelae.

Liver function tests should be performed before the initiation of treatment, and periodically thereafter. Special attention should be paid to patients who develop elevated serum transaminase levels, and in these patients meacurements should be repeated promptly and then performed more frequently.

If increases in alanine aminotransferase (ALT) or aspartate aminotransferase (AST) show evidence of progression, particularly if they rise to greater than 3 times the upper limit of normal and are persistent, the dosage should be reduced or the drug discontinued.

LPITOR should be used with caution in patients who consume substantial quantities of alcohol and/or have a pas history of liver disease. Active liver disease or unexplained transaminase elevations are contraindications to the use of LIPITOR; if such a condition should develop during therapy, the drug should be discontinued.

\section{Muscle Effects}

Myopathy defined as muscle aching or muscle weakness in conjunction with increases in creatinine phosphokinase (CPK) values to greater than ten times the upper limit of normal, should be considered in any patient with diffuse myalgia muscle tenderness or weakness, and/or marked elevation of CPK. Patients should be advised to report promptly unexplained muscle pain, tenderness or weakness, particularly if accompanied by malaise or fever. LPITOR therapy should be discontinued if markedly elevated CPK levels occur or myopathy is diagnosed or suspected. The risk of myopathy an rhabdomyolysis during treatment with HMG-COA reductase inhibitors is increased with concurrent administration of cyclosporin, fibric acid derivatives, erythromycin, clarithromycin, niacin (nicotinic acid), azole antifungals or nefazodone As there is no experience to date with the use of LIPITOR given concurrently with these drugs, with the exception o pharmacokinetic studies conducted in healthy subjects with erythromycin and clarithromycin, the benefits and risks of such combined therapy should be carefully considered (see PRECAUTIONS, Pharmacokinetic Interaction Studies and Potentia Drug Interactions).

Rhabdomyolysis has been reported in very rare cases with LIPITOR (see PRECAUTIONS, Drug Interactions).

Rhabdomyolysis with renal dysfunction secondary to myoglobinuria has also been reported with HMG-CoA reductase inhibitors. LIPTOR therapy should be temporarily withheld or discontinued in any patient with an acute serious condition suggestive of a myopathy or having a risk factor predisposing to the development of renal failure secondary to rhabdomyolysis (such as severe acute infection, hypotension, major surgery, trauma, severe metabolic, endocrine an electrolyte disorders, and uncontrolled seizures)

PRECAUTIONS

General

Before instituting therapy with LIPITOR (atorvastatin calcium), an attempt should be made to control elevated serum lipoprotein levels with appropriate diet, exercise, and weight reduction in overweight patients, and to treat other underlying medical problems (see INDICATIONS AND CLINICAL USE). Patients should be advised to inform subsequent physicians of the prior use of LIPITOR or any other lipid-lowering agents.

Effect on the Lens

Current long-term data from clinical trials do not indicate an adverse effect of atorvastatin on the human lens.

Effect on Ubiquinone $\left(\mathrm{Co}_{10}\right)$ Levels

Significant decreases in circulating ubiquinone levels in patients treated with atorvastatin and other statins have been observed. The clinical significance of a potential long-term statin-induced deficiency of ubiquinone has not been established. It has been reported that a decrease in myocardial ubiquinone levels could lead to impaired cardiac function in patients with borderline congestive heart failure

Effect on Lipoprotein (a)

In some patients, the beneficial effect of lowered total cholesterol and LDL-C levels may be partly blunted by a concomitant increase in $L p(a)$ lipoprotein concentrations. Present knowledge suggests the importance of high $L p(a)$ levels as an emerging risk factor for coronary heart disease. It is thus desirable to maintain and reinforce lifestyle changes in high risk patients placed on atorvastatin therapy.

Hypersensitivity

An apparent hypersensitivity syndrome has been reported with other HMG-COA reductase inhibitors which has included 1 or more of the following features: anaphylaxis, angioedema, lupus erythematous-like syndrome, polymyalgia rheumatica vasculitis, purpura, thrombocytooenia, leukopenia, hemolytic anemia, positive ANA, ESR increase, eosinophilia, arthritis, arthragi urticaria asthenia photosensitivity fever, chills, flushing mase dyspnea, toxic epidermal necrolysis, enthem multiforme, including Stevens-Johnson syndrome. Although to date hypersensitivity syndrome has not been described as such, LPITOR should be discontinued if hypersensitivity is suspected.

\section{Use in Pregnancy}

LIPITOR is contraindicated during pregnancy (see CONTRAINDICATIONS)

Atherosclerosis is a chronic process and discontinuation of lipid-lowering drugs during pregnancy should have little impact on the outcome of long-term therapy of primary hypercholesterolemia. Cholesterol and other products of cholestero biosynthesis are essential components for fetal development (including synthesis of steroids and cell membranes). Since 
HMG-CoA reductase inhibitors decrease cholesterol synthesis and possibly the synthesis of other biologically active substances derived from cholesterol, they may cause harm to the fetus when administered to pregnant women.

There are no data on the use of LIPTOR during pregnancy. LPTTOR should be administered to women of childbearing age only when such patients are highly unlikely to conceive and have been informed of the potential hazards. If the patient becomes pregnant while taking LPITOR, the drug should be discontinued and the patient apprised of the potential risk to the fetus.

\section{Nursing Mothers}

in rats, milk concentrations of atorvastatin are similar to those in plasma. It is not known whether this drug is excreted in human milk. Because of the potential for adverse reactions in nursing infants, women taking LIPITOR should not breastfeed (see CONTRAINDICATIONS)

Pediatric Use

Ireatment experience in a pediatric population is limited to doses of LIPITOR up to $80 \mathrm{mg} /$ day for 1 year in 8 patients with homozygous familial hypercholesterolemia. No clinical or biochemical abnormalities were reported in these patients. Geriatric Use

Treatment experience in adults 70 years or older $(\mathrm{N}=221)$ with doses of $L I P I T O R$ up to $80 \mathrm{mg} /$ day has demonstrated that the satety and effectiveness of atorvastatin in this population was similar to that of patients $<70$ years of age the satety and effectiveness of atorvastatin in this population was similar to that of patients $<70$ years of age. tionary measure, the lowest dose should be administered initially.

\section{Renal Insufficiency}

Plasma concentrations and LDL-C lowering efficacy of $\triangle P P T O R$ was shown to be similar in patients with moderate rena insufficiency compared with patients with normal renal function. However, since several cases of rhabdomyolysis have been reported in patients with a history of renal insufficiency of unknown severity, as a precautionary measure and pending further experience in renal disease, the lowest dose $(10 \mathrm{mg} /$ day) of LIPIOR should be used in these patients. Similar precautions apply in patients with severe renal insufficiency [creatinine clearance $<30 \mathrm{~mL} / \mathrm{min}(<0.5 \mathrm{~mL} / \mathrm{sec})$ ); the lowest dosage should be used and implemented cautiously (see WARNINGS, Muscle Effects; PRECAUTIONS, Drug Interactions). Refer also to DOSAGE AND ADMINISTRATION.

\section{Endocrine Function}

HMG-COA reductase inhibitors interfere with cholesterol synthesis and as such might theoretically blunt adrenal and/o gonadal steroid production. Clinical studies with atorvastatin and other HMG-COA reductase inhibitors have suggested that these agents do not reduce plasma cortisol concentration or impair adrenal reserve and do not reduce basal plasma estosterone concentration. However, the effects of HMG-COA reductase inhibitors on male fertility have not been studied in adequate numbers of patients. The effects, if any, on the pituitary-gonadal axis in premenopausal women are unknown. Patients treated with atorvastatin who develop clinical evidence of endocrine dysfunction should be evaluate appropriately. Caution should be exercised if an HMG-COA reductase inhibitor or other agent used to lower cholestero levels is administered to patients receiving other drugs (e.g. ketoconazole, spironolactone or cimetidine) that may decrease the levels of endogenous steroid hormones.

\section{Pharmacokinetic Interaction Studies and Potential Drug Interactions}

Pharmacokinetic interaction studies conducted with drugs in healthy subjects may not detect the possibility of a potentia drug interaction in some patients due to differences in underlying diseases and use of concomitant medications (see als Geriatric Use; Renal Insufficiency; Patients with Severe Hypercholesterolemia).

Concomitant Therapy with Other Lipid Metabolism Regulators: Combined drug therapy should be approached with caution as information from controlled studies is limited.

\section{Bile Acid Sequestrants:}

Patients with mild to moderate hypercholesterolemia: LOL-C reduction was greater when LIPITOR $10 \mathrm{mg}$ and colestipo $20 \mathrm{~g}$ were coadministered (-45\%) than when either drug was administered alone (-35\% for LIPITOR and -22\% for colestipo). Patients with severe hypercholesterolemia: LDL-C reduction was similar (-53\%) when LIPITOR $40 \mathrm{mg}$ and colestipol $20 \mathrm{~g}$

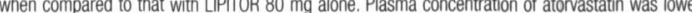
(approximately 26\%) when LIPITOR $40 \mathrm{mg}$ plus colestipol $20 \mathrm{~g}$ were coadministered compared with LIPITOR $40 \mathrm{mg}$ alone. However, the combination drug therapy was less effective in lowering the triglycerides than LIPITOR monotherapy in both types of hypercholesterolemic patients.

When LIPITOR is used concurrently with colestipol or any other resin, an interval of at least 2 hours should be maintained between the two drugs, since the absorption of LPITOR may be impaired by the resin.

Fibric Acid Derivatives (Gemfibrozil, Fenofibrate, Bezafibrate) and Niacin (Nicotinic Acid): Although there is limited experience with the use of LIPITOR given concurrently with fibric acid derivatives and niacin, the benefits and risk of such combined therapy should be carefully considered. The risk of myopathy during treatment with other drugs in this class, including atorvastatin, is increased with concurrent administration (see WARNINGS, Muscle Effects)

Coumarin Anticoagulants: LPITOR had no clinically significant effect on prothrombin time when administered to patients receiving chronic warfarin therapy.

Digoxin: In healthy subjects, digoxin pharmacokinetics at steady-state were not significantly altered by coadministration fo digoxin $0.25 \mathrm{mg}$ and $\amalg$ PITOR $10 \mathrm{mg}$ daily. However, digoxin steady-state concentrations increased approximately $20 \%$ following coadministration of digoxin $0.25 \mathrm{mg}$ and LPITOR $80 \mathrm{mg}$ daily. Patients taking digoxin should be monitored appropriately.

Antihypertensive agents (amlodipine): In clinical studies, LIPITOR was used concomitantly with antihypertensive agents without evidence to date of clinically significant adverse interactions. In healthy subjects, atorvastatin pharmaco kinetics were not altered by the coadministration of LIPITOR $80 \mathrm{mg}$ and amlodipine $10 \mathrm{mg}$ at steady state (quinapril): In a randomized, open-label study in healthy subjects, steady-state quinapril dosing (80 mg QD) did not significantly affect the pharmacokinetic profile of atorvastatin tablets (10 $\mathrm{mg}$ QD).

Oral Contraceptives and Hormone Replacement Therapy: Coadministration of LPITOR with an oral contraceptive, containing $1 \mathrm{mg}$ norethindrone and $35 \mu \mathrm{g}$ ethinyl estradiol, increased plasma concentrations (AUC levels) of norethindron and ethinyl estradiol by approximately $30 \%$ and $20 \%$, respectively. These increases should be considered when selecting an oral contraceptive. In clinical studies, LIPTOR was used concomitantly with estrogen replacement therapy without evidence to date of clinically significant adverse interactions.

Antacids: Administration of aluminum and magnesium based antacids, such as Maalox TC Suspension, with LIPITOR decreased plasma concentrations of LIPITOR by approximately $35 \%$. LDL-C reduction was not altered but the triglyceridelowering effect of LIPITOR may be affected.

Cimetidine: Administration of cimetidine with LIPITOR did not alter plasma concentrations or LDL-C lowering efficacy of LIPITOR, however, the triglyceride-lowering effect of LIPIOR was reduced from $34 \%$ to $26 \%$.

Cytochrome P-450-mediated Interactions: Atorvastatin is metabolized by the cytochrome P-450 isoenzyme, CYP 3 A4 Erythromycin, a CYP $3 \mathrm{~A} 4$ inhibitor increased atorvastatin plasma levels by $40 \%$. Coadministration of CYP $3 \mathrm{~A} 4$ inhibitors,

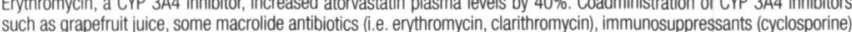
azole antifungal agents (i.e. itraconazole, ketoconazole), protease inhibitors, or the antidepressant, nefazodone, may have the potential to increase plasma concentrations of HMG-COA reductase inhibitors, including LPITOR. Caution should thus the potential to increase plastma concentrations of HMG-COA reductase inhibitors, including LIPTIOR. Caution should thus be exercised with concomitant use of these agents (see WARNINGS, Pharmacokinetic In

PRECAUTIONS, Renal Insufficiency and Endocrine Function; DOSAGE AND ADMINISTRATION). In healthy subjects, coadministration of maximum doses of both atorvastatin $(80 \mathrm{mg})$ and terfenadine $(120 \mathrm{mg})$, a CYP $3 \mathrm{~A}$ substrate, was shown to produce a modest increase in terfenadine AUC. The QTC interval remained unchanged. However since an interaction between these two drugs cannot be excluded in patients with predisposing factors for arrhythmia these agents are coadministered (see WARNINGS, Pharmacokinetic Interactions; DOSAGE AND ADMINISTRATION).

Antipyrine: Antipyrine was used as a non-specific model for drugs metabolized by the microsomal hepatic enzyme system (cytochrome P-450 system). LPPTOR had no effect on the pharmacokinetics of antipyrine, thus interactions with other drugs metabolized via the same cytochrome isozymes are not expected.

Macrolide Antibiotics (azithromycin, clarithromycin, erythromycin): In healthy adults, coadministration of LPITOP $(10 \mathrm{mg} \mathrm{QD})$ and azithromycin (500 mg QD) did not significantly alter the plasma concentrations of atorvastatin. Howeve coadministration of atorvastatin (10 mg QD) with erythromycin (500 mg QID) or clarithromycin (500 mg BID), which are both CYP $3 A 4$ inhibitors, increased plasma concentrations of atorvastatin approximately $40 \%$ and $80 \%$, respectively (see WARNINGS, Muscle Effects).

Protease Inhibitors (nelfinavir mesylate): In healthy adults, coadministration of nelfinavir mesylate (1250 mg BID), known CYP $3 A 4$ inhibitor, and atorvastatin (10 mg QD) resulted in increased plasma concentrations of atorvastatin. AUC and $\mathrm{C}_{\text {max }}$ of atorvastatin were increased by $74 \%$ and $122 \%$ respectively.

Patients with Severe Hypercholesterolemia: Higher drug dosages $(80 \mathrm{mg} /$ day) required for some patients with severe ypercholesterolemia (including familial hypercholesterolemia) are associated with increased plasma levels of atorvastatin. Caution should be exercised in such patients who are also severely renally impaired, elderly, or are concomitantly being administered digoxin or CYP 3 A4 inhibitors (see WARNINGS, Pharmacokinetic Interactions, Muscle Effects; PRECAUTIONS, Drug Interactions; DOSAGE AND ADMINISTRATION).
Drug/Laboratory Test Interactions

LPITOR may elevate serum transaminase and creatinine phosphokinase levels (from skeletal muscle). In the differential diagnosis of chest pain in a patient on therapy with LPITOR, cardiac and noncardiac fractions of these enzymes should be determined. ADVERSE REACTIONS

UPITOR is generally well-tolerated. Adverse reactions have usually been mild and transient. In controlled clinical studies (placebocontrolled and active-controlled comparative studies with other lipid lowering agents) involving 2502 patients, $<2 \%$ of patients were discontinued due to adverse experiences attributable to LIPTOR. Of these 2502 patients, 1721 were treated for at least 6 months and 1253 for 1 year or more.

Adverse experiences occurring at an incidence $\geq 1 \%$ in patients participating in placebo-controlled clinical studies of UPTOR and eported to be possibly, probably or definitely drug related are shown in Table 1 below:

\section{TABLE 1. Associated Adverse Events Reported in $\geq 1 \%$ of Patients in Placebo-Controlled Clinical Trials}

\begin{tabular}{rr}
\hline GASTROINTESTINAL & \\
Constipation & 1 \\
Diarnea & 1 \\
Dyspepsia & 2 \\
Flatulence & 2 \\
Nausea & 0 \\
NERVOUS SYSTEM & \\
Headache & 2 \\
MISCELLANEOUS & \\
Pain & $<1$ \\
Myalgia & 1 \\
Asthenia & $<1$
\end{tabular}

The following additional adverse events were reported in clinical trials; not all events listed below have been associate with a causal relationship to LIPITOR therapy: Muscle cramps, myositis, myopathy, paresthesia, peripheral neuropathy, pancreatitis, hepatitis, cholestatic jaundice, anorexia, vomiting, alopecia, pruritus, rash, impotence, hyperglycemia, an hypoglycemia.

Post-marketing experience: Very rare reports: severe myopathy with or without rhabdomyolysis (see WARNINGS, Muscle Effects; PRECAUTIONS, Renal Insufficiency and Drug Interactions). Isolated reports: thrombocytopenia, arthralgia and allergic reactions including urticaria, angioneurotic edema, anaphylaxis and bullous rashes (including erytheme multiforme Stevens-Johnson syndrome and toxic epidermal necrolysis)]. These may have no causal relationship to atorvastatin.

Ophthalmologic observations: see PRECAUTIONS

Laboratory Tests: Increases in serum transaminase levels have been noted in clinical trials (see WARNINGS)

\section{DOSAGE AND ADMINISTRATION}

Patients should be placed on a standard cholesterol-lowering diet [at least equivalent to the Adult Treatment Panel II (ATP III) TLC diet] before receiving LIPITOR, and should continue on this diet during treatment with LIPITOR. If appropriate a program of weight control and physical exercise should be implemented.

Primary Hypercholesterolemia and Combined (Mixed) Dyslipidemia. Including Familial Combined Hyperlipidemia

The recommended starting dose of LIPITOR is 10 or $20 \mathrm{mg}$ once daily. Patients who require a large reduction in LDL-C (more than $45 \%$ ) may be started at $40 \mathrm{mg}$ once daily. The dosage range of LIPITOR is 10 to $80 \mathrm{mg}$ once daily. Doses can be given at any time of the day, with or without food, and should preferably be given in the evening. Doses should be individualized according to the level of risk; the baseline LDL-C and/or TG levels; the desired LDL-C and/or TG target, and/or TC/HDL-C target (see the Detection and Management of Hypercholesterolemia. Working Group on Hypercholesterolemia and other Dyslipidemias [Canada] and/or the US National Cholesterol Education Program [NCEP Adult Treatment Panel III]) the goal of therapy and the patient's response. A significant therapeutic response is evident within 2 weeks, and the maximum response is usually achieved within 2-4 weeks. The response is maintained during chronic therapy. Adjustments of dosage, if necessary, should be made at intervals of $2-4$ weeks. The maximum dose is $80 \mathrm{mg} /$ day.

Lipid levels should be monitored periodically and, if necessary, the dose of LIPITOR adjusted based on targe lipid levels recommended by guidelines.

The following reductions in total cholesterol and LDL-C levels have been observed in 2 dose-response studies, and may serve as a guide to treatment of patients with mild to moderate hypercholesterolemia

TABLE 2. Dose-Response in Patients With Mild to Moderate Hypercholesterolemi (Mean Percent Change from Baseline)

\begin{tabular}{|c|c|c|c|c|}
\hline \multirow{2}{*}{ Lipid Parameter } & \multicolumn{4}{|c|}{ LPTTOR Dose (mg/day) } \\
\hline & $\begin{array}{c}10 \\
(\mathrm{~N}=22)\end{array}$ & $\begin{array}{c}20 \\
\mathbb{N}=20)\end{array}$ & $\begin{array}{c}40 \\
N=21)\end{array}$ & $\begin{array}{c}80 \\
N=23\end{array}$ \\
\hline $\begin{array}{l}\text { Total-C: } 7.1 \mathrm{mmol}^{\circ} \\
\text { (273 mg/dL) }^{\circ}\end{array}$ & -29 & -33 & -37 & -45 \\
\hline $\begin{array}{l}\text { WL-C: } 4.9 \mathrm{mmo} / \mathrm{L}^{\circ} \\
(190 \mathrm{mg} / \mathrm{dL})^{\circ}\end{array}$ & -39 & -43 & -50 & -60 \\
\hline
\end{tabular}

Results are pooled from 2 dose-response studies

Mean baseline values

Severe Dyslipidemias

In patients with severe dyslipidemias, including homozygous and heterozygous familial hypercholesterolemia and dysbetalipoproteinemia (Type III), higher dosages (up to $80 \mathrm{mg} /$ day) may be required (see WARNINGS, Pharmacokinetic Interactions, Muscle Effects; PRECAUTIONS, Drug Interactions)

Concomitant Therapy

See PRECAUTIONS, Drug Interactions.

Dosage in Patients With Renal Insufficiency

See PRECAUTIONS

\section{AVAILABIUTY OF DOSAGE FORM}

LIPITOR (atorvastatin calcium) is available in dosage strengths of $10 \mathrm{mg}, 20 \mathrm{mg}, 40 \mathrm{mg}$ and $80 \mathrm{mg}$ atorvastatin per tablet $10 \mathrm{mg}:$ White, elliptical, film-coated tablet, coded "10" on one side and "PD 155" on the other. Available in bottles of 90 tablets. $20 \mathrm{mg}$ : White, elliptical, film-coated tablet, coded " 20 " on one side and "PD 156" on the other. Available in bottles of 90 tablets 40 mg: White, elliptical, film-coated tablet, coded "40" on one side and "PD 157" on the other. Available in bottles of 90 tablets. $80 \mathrm{mg}$ : White, elliptical, film-coated tablet, coded " 80 " on one side and "PD 158" on the other. Available in blisters of 30 tablets (3 strips $\times 10)$.

For a copy of the Product Monograph or full Prescribing Information, please contact:

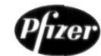

Life is our life's work

C2005

Pfizer Canada Inc

Kirkland, Q
H9J $2 \mathrm{MS}$

TM Pfizer treland Pharmacenticats

Pfizer Canada Inc., licensee 


\section{'Ebixa memantine}

Memantine Hydrochloride Tablets $10 \mathrm{mg}$ THERAPEUTIC CLASSIFICATION: $\mathrm{N}$-methyl-D-aspartate (NMDA)

receptor antagonist

EBIXA ${ }^{\oplus}$, indicated for the symptomatic treatment of patients with moderate to severe dementia of the Alzheimer's type, has been issued marketing authorization with conditions, to reflect the promising nature of the clinical evidence and the need for a confirmatory study to verify the clinical benefit. Patients should be advised of the nature of the authorization assessment

ACTION AND CLINICAL PHARMACOLOGY: Persistent activation of the central nervous system $\mathrm{N}$-methyl-D-aspartate (NMDA) receptors by the excitatory amino acid glutamate has been hypothesize to contribute to the symptomatology of Alzheimer's disease. Memantine is postulated to exert its therapeutic effect through its action as a low to moderate affinity uncompetitive (open channel) NMDA receptor antagonist, which binds preferentially to the NMDA receptor-operated cation channels. It blocks the effects of pathologically elevated sustained levels of glutamate that may lead to neuronal dysfunction. There is no clinical evidence that memantine prevents or slows neurodegeneration or alters the course of the underlying dementing process in patients with Alzheimer's disease. Memantine exhibits low to negligible affinity for other receptors (GABA, benzodiazepine, dopamine, adrenergic, noradrenergic, histamine and glycine) or voltage-dependent $\mathrm{Ca}^{2 *} \mathrm{Na}^{*}$ or $\mathrm{K}^{*}$ channels. In addition, it does not directly affect the acetylcholine receptor or cholinergic transmission, which have been implicated in the cholinomimetic side effects (e.g., increased gastric acid secretion, nausea and vomiting) seen with acetylcholinesterase inhibitors. Memantine showed antagonist effects at the $5 \mathrm{HT}_{3}$ receptor with a potency similar to that for the NMDA receptor. In vitro studies have shown that memantine does not affect the reversible inhibition of acetylcholinesterase by donepezil or galantamine.

PHARMACOKINETICS: ABSORPTION: Orally administered memantine is completely absorbed. Ora bioavailability is almost $100 \%$. Time to maximum plasma concentration $\left(t_{\max }\right)$ following single oral doses of 10 to $40 \mathrm{mg}$ memantine ranged between 3 to 8 hours. It has a terminal elimination half-life of about 60-80 hours, with the majority of the dose excreted unchanged in urine. There is no indication that food influences the absorption of memantine. Studies in volunteers have demonstrated linea pharmacokinetics in the dose range of 10 to $40 \mathrm{mg}$. Daily doses of $20 \mathrm{mg}$ lead to steady-state plasma concentrations of memantine ranging from 70 to $150 \mathrm{ng} / \mathrm{ml}(0.5-1 \mu \mathrm{M})$ with large inter-individua variations. DISTRIBUTION: The apparent volume of distribution of memantine is approximately $9-11 \mathrm{~L} / \mathrm{kg}$ and the plasma protein binding is approximately $45 \%$. Memantine rapidly crosses the blood-brain barrie with a CSF/serum ratio of about 0.5. METABOLISM AND ELIMINATION: In a study using orally administered $14 \mathrm{C}$-memantine, a mean of $84 \%$ of the dose was recovered within 20 days, more than $99 \%$ being excreted renally. Memantine undergoes little metabolism being in majority excreted unchanged in urine $(75-90 \%)$. The remaining dose is converted primarily to three polar metabolites: the $\mathrm{N}$-gludantan conjugate, 6-hydroxy memantine and 1-nitroso-deaminated memantine. These metabolites possess minimal NMDA receptor antagonist activity. The hepatic microsome CYP450 enzyme system does not play a significant role in the metabolism of memantine. In volunteers with normal kidney function, tota clearance $\left(\mathrm{Cl}_{\text {tot }}\right)$ amounts to $170 \mathrm{ml} / \mathrm{min} / 1.73 \mathrm{~m}^{2}$ and part of total renal clearance is achieved by tubular secretion. Renal handling also involves tubular reabsorption, probably mediated by cation transpor proteins. The renal elimination rate of memantine under alkaline urine conditions may be reduced by factor of 7 to 9 resulting in increased plasma levels of memantine (see WARNINGS, Genitourinary Conditions). Alkalisation of urine may result from drastic changes in diet, e.g. from a carnivore to a vegetarian diet, or from the massive ingestion of alkalising gastric buffers. SPECIAL POPULATIONS: ELDERLY PATIENTS: The pharmacokinetics of memantine in young and elderly subjects is similar. No adjustment of dosage on the basis of age is recommended. REDUCED HEPATIC FUNCTION: The pharmacokinetics of memantine in patients with hepatic impairment has not been investigated. As memantine is metabolized to a minor extent into metabolites with no NMDA-antagonistic activity. changes in the pharmacokinetics are not expected to result in clinically relevant effects in patients with mild to moderate liver impairment. REDUCED RENAL FUNCTION: In elderly volunteers with normal and reduced renal function (creatinine clearance of 50 to $\leq 80 \mathrm{ml} / \mathrm{min} / 1.73 \mathrm{~m}^{2}$ ), a significant correlation was observed between creatinine clearance and total renal clearance of memantine. Following a single $20 \mathrm{mg}$ oral dose of memantine. systemic exposure in geriatric subjects with mild and moderate rena impairment was $14 \%$ and $39 \%$ greater, respectively, compared to geriatric subjects with normal rena function (see PRECAUTIONS and DOSAGE AND ADMINISTRATION).

NOC/C - CLINICAL TRIALS: The potential efficacy of EBIXA ${ }^{\circ}$ (memantine hydrochloride) as treatment for the symptomatic management of moderate to severe Alzheimer's disease was demonstrated by the results of 2 randomized, double-blind, placebo-controlled 6-month clinical studies. Both studies were conducted in patients with Alzheimer's disease. The mean age of patients participating in the EBIXA trials was 76 with a range of 50 to 93 years. Approximately $66 \%$ of patients were women. Female patients participating in the clinical trials were required to be at least 50 years of age and at leas 2 years postmenopausal or surgically sterile. The racial distribution was approximately $91 \%$ Caucasian. Study Outcome Measures: In each study, the effectiveness of EBIXA* was determined from instruments evaluating activities of daily living through caregiver-related evaluation, a measure of cognition, and clinician's global assessment of change. The ability of EBIXA ${ }^{\circ}$ to improve day-to-day function was assessed in both studies (Study 1 and Study 2) using the modified Alzheimer's Disease Cooperative

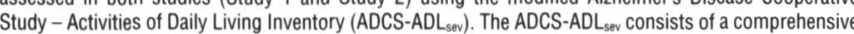
battery of $A D L$ questions used to measure the functional capabilities of patients. Each $A D L$ item is rated from the highest level of independent performance to complete loss. The inventory is performed by interviewing a caregiver familiar with the behaviour of the patient. The modified ADCS-ADLs consists of a subset of 19 items including ratings of the patients' ability to eat, dress, bathe, telephone, travel, shop, and perform other household chores, and has been validated for the assessment of patients

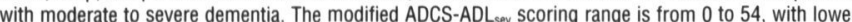
scores indicating greater functional impairment. The ability of EBIXA ${ }^{\oplus}$ to improve cognitive performance was assessed in both studies (Study 1 and Study 2) with the Severe Impairment Battery (SIB), a multiitem instrument that has been validated for the evaluation of cognitive function in patients with moderate to severe dementia. Unlike the Alzheimer's Disease Assessment Scale - cognitive subscale (ADAS-cog) the sensitivity of the SIB is not limited by floor effects in patients with advanced dementia. The SIB examines selected aspects of cognitive performance including elements of attention, orientation, language, memory, visuospatial ability, construction, praxis, and social interaction. The SIB scoring range is from 0 to 100, with lower scores indicating greater cognitive impairment. The SIB has been shown to be a valid and reliable instrument sensitive to longitudinal changes in patients with moderate to severe dementia. The ability of EBIXA to produce an overall clinical effect was assessed in both studies (Study and Study 2) using a Clinician's Interview Based Impression of Change that required the use of caregiver information, the CIBIC-Plus. The CIBIC-Plus used in both trials was a structured instrument based on a comprehensive evaluation at baseline and subsequent time-points of four domains: general (overall clinical status), functional (including activities of daily living), cognitive, and behavioural. It represents the assessment of a skilled clinician using validated scales based on his/her observation at an interview with the patient, in combination with information supplied by a caregiver familiar with the behaviour of the patient over the interval rated. The CIBIC-Plus is scored as a seven point categorical rating, ranging from a score of 1 , indicating "markedly improved" to a score of 4 , indicating "unchanged" to a score of 7 , indicating "markedly worse." The CIBIC-Plus has not been systematically compared directly to assessments not using information from caregivers (CIBIC) or other global methods. Study 1 (TwentyEight-Week Study): In a study of 28 weeks duration, 252 patients with moderate to severe Alzheimer's disease (diagnosed by DSM-IV and NINCDS-ADRDA criteria, with Mini-Mental State Examination scores $\geq 3$ and $\leq 14$ and Global Deterioration Scale Stages $5-6$ ) were randomized to EBIXA ${ }^{*}$ or placebo. For patients randomized to EBIXA ${ }^{\star}$, treatment was initiated at $5 \mathrm{mg} /$ day and increased weekly by $5 \mathrm{mg} /$ day a dose of $20 \mathrm{mg} /$ day ( $10 \mathrm{mg}$ twice a day). The percentages of randomized patients who completed the study were: placebo $67 \%$ and EBIXA $77 \%$. Results are presented for analyses based on all patients (ITT, Intent-to treat population) and carrying their last study observation forward (LOCF analysis). Primary efficacy endpoints were the ADCS-ADL sev $_{\text {and }}$ CIBIC-Plus. Effects on the ADCS-ADL sev: Figure 1 illustrates the time course for the change from baseline in the ADCS-ADL sev score for the two treatment groups over the 28 weeks of the study. At endpoint, the mean difference in the ADCS-ADL $L_{\text {sev }}$ change scores for the $E B I X A^{\ominus}$-treated patients compared to the patients on placebo was 2.1 units $(p=0.022)$. EBIXA ${ }^{\circ}$ treatment was statistically significantly superior to placebo.

Figure 1: Time course of the change from baseline in ADCS-ADL sev $_{\text {Score }}$ at week 28-LOCF (ITT population)

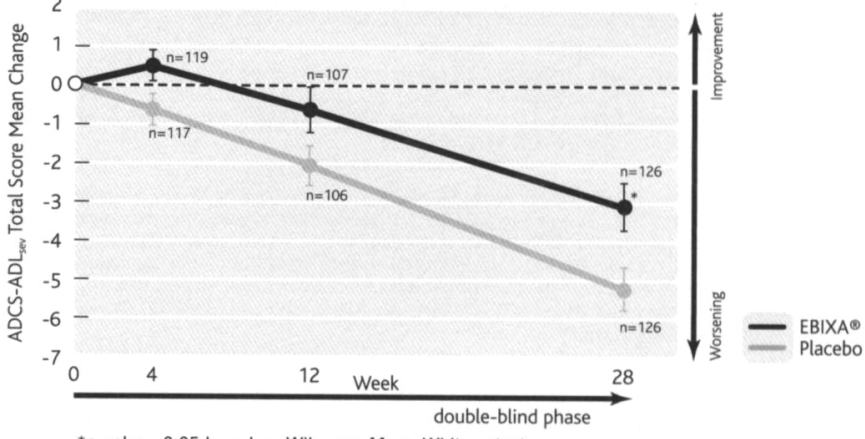

${ }^{*} \mathrm{p}$-value $<0.05$ based on Wilcoxon-Mann-Whitney test.

LOCF

Effects on the CIBIC-Plus: Figure 2 is a histogram of the percentage distribution of CIBIC-Plus scores attained by patients assigned to each of the treatment groups. The EBIXA ${ }^{\oplus}$-placebo difference for these groups of patients in the mean rating was 0.25 units $(p=0.06)$. EBIXA $A^{\infty}$ treatment was numerically superior but not statistically significantly superior to placebo.

Figure 2: Distribution of CIBIC-Plus ratings at week 28-LOCF (ITT population)

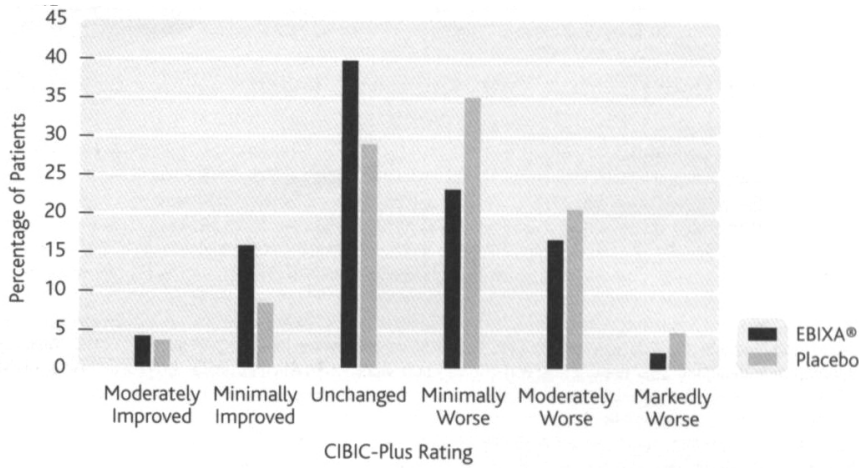

Effects on the SIB: The Severe Impairment Battery was used as a secondary efficacy measure. At study endpoint, the mean difference in the SIB change scores from baseline for the EBIXA-treated patients compared to the patients on placebo was 5.9 units $(\mathrm{p}<0.001)$. EBIXA* treatment was statistically significantly superior to placebo. Study 2 (Twenty-Four-Week Study): In a study of 24 weeks duration, 404 patients with moderate to severe Alzheimer's disease (diagnosed by NINCDS-ADRDA criteria, with Mini-Mental State Examination scores $\geq 5$ and $\leq 14$ ) who had been treated with donepezil for at least 6 months and who had been on a stable dose of donepezil for 3 months prior to randomization were then randomized to $\mathrm{EBIXA}^{\star}$ or placebo, while still receiving donepezil. For patients randomized to EBIXA treatment was initiated at $5 \mathrm{mg} /$ day and increased weekly by $5 \mathrm{mg} /$ day to a dose of $20 \mathrm{mg} /$ day $(10 \mathrm{mg}$ twice a day). The percentages of randomized patients who completed the study were: placebo/donepezil $75 \%$ and EBIXA $\%$ donepezil $85 \%$. The primary endpoints were the ADCS-ADL $L_{\text {sev }}$ and SIB. Effects on the ADCS-ADL sev: Figure 3 illustrates the time course for the change from baseline in the ADCS-ADLsev Scor for the two treatment groups over the 24 weeks of the study. The mean difference in the ADCS-ADLse change scores for the EBIXA*/donepezil treated patients compared to the patients on placebo/donepezil was 1.4 units $(p=0.028)$. EBIXA $\%$ donepezil treatment was statistically significantly superior to placebo/donepezil.

Figure 3: Time course of the change from baseline in ADCS-ADL $L_{\text {sev }}$ score at 24 weeks-LOCF (ITT Population)

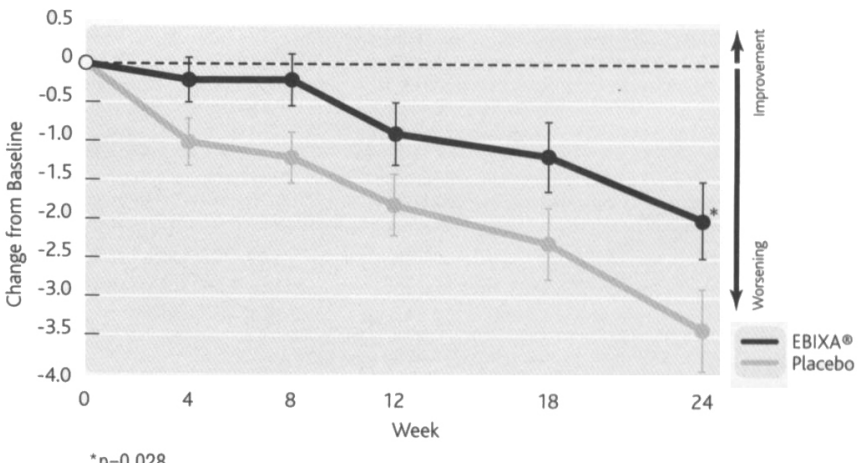

Effects on the SIB: Figure 4 illustrates the time course for the change from baseline in SIB score for the two treatment groups over the 24 weeks of the study. The mean difference in the SIB change scores for the EBIXA $/$ donepezil treated patients compared to the patients on placebo/donepezil was 3.4 units $(\mathrm{p}<0.001)$. $E B \mid X A^{\circledast} /$ donepezil treatment was statistically significantly superior to placebo/donepezil. 


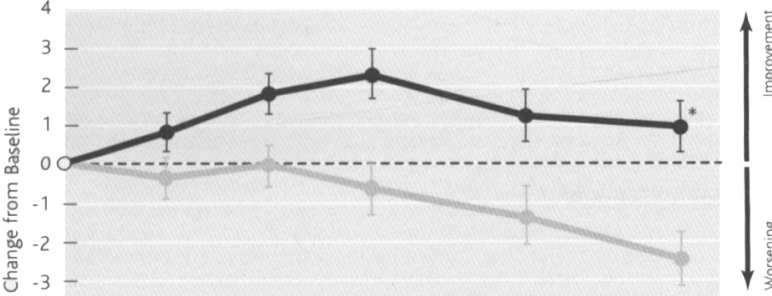

$\mathrm{p} p<0.001$

Effects on the CIBIC-Plus: The CIBIC-Plus was used as a secondary efficacy measure. The EBIXA placebo difference of $C|B| C$-Plus mean rating was 0.25 units $(p=0.027)$. EBIXA $/$ donepezil treatment was statistically significantly superior to placebo/donepezil.

NOC/C INDICATION AND CLINICAL USE: EBIXA (memantine hydrochloride) may be useful as monotherapy or as adjunctive therapy with cholinesterase inhibitors' for the symptomatic treatment of patients with moderate to severe dementia of the Alzheimer's type. EBIXA ${ }^{\star}$ tablets should only be prescribed by (or following consultation with) clinicians who are experienced in the diagnosis and management of Alzheimer's disease. In a 28 -week placebo controlled monotherapy trial, patients with moderate to severe Alzheimer's disease showed stabilization or less worsening of functional and cognitive symptoms and of global assessment when treated with EBIXA ${ }^{\oplus}$ compared to placebo. In a 24 week "add-on" placebo controlled trial in which patients were treated with either EBIXA or placebo as add-on to ongoing donepezil therapy, stabilization or less worsening of functional and cognitive symptoms and of global assessment was observed in patients with moderate to severe Alzheimer's disease when treated with EBIXA compared to placebo. EBIXA ${ }^{\star}$ has not been studied in controlled clinical trials for the symptomatic treatment of moderate to severe Alzheimer's disease for more than 6 months

Cholinesterase inhibitors refers to only those which are approved in Canada for the symptomatic treatment of Alzheimers disease.

CONTRAINDICATIONS: EBIXA (memantine hydrochloride) is contraindicated in patients with known hypersensitivity to memantine hydrochloride or to any excipients used in the formulation.

WARNINGS: NEUROLOGICAL CONDITIONS: Seizures: EBIXA ${ }^{\circ}$ (memantine hydrochloride) has not been systematically evaluated in patients with a seizure disorder. These patients were excluded from clinical studies during the premarketing testing of EBIXA ${ }^{*}$. In clinical trials, seizures occurred in $0.3 \%$ patients treated with EBIXA ${ }^{\circ}$ and $0.4 \%$ of patients treated with placebo. Seizure activity may be manifestation of Alzheimer's disease. The risk/benefit of memantine treatment for patients with a histor of seizure disorder must therefore be carefully evaluated. GENITOURINARY CONDITIONS: Condition that raise urine $\mathrm{pH}$ may reduce the urinary elimination of memantine by a factor of 7 to 9 , resulting in increased plasma levels of memantine (see ACTIONS AND CLINICAL PHARMACOLOGY). Thes conditions include drastic changes in diet, e.g. from a carnivore to a vegetarian diet, or a massive ingestion of alkalising gastric buffers (see Drugs Which Make Urine Alkaline, PRECAUTIONS). Also, urin $\mathrm{pH}$ may be elevated by states of renal tubulary acidosis (RTA) or severe infections of the urinary tract with Proteus bacteria. CARDIOVASCULAR CONDITIONS: In most clinical trials, patients with recent myocardial infarction, uncompensated congestive heart failure (NYHA III-IV), and uncontrolled hypertension were excluded. However, patients such as those with controlled hypertension (DBP $<105 \mathrm{~mm} / \mathrm{Hg}$ ), right bundle branch blockage and pacemaker were included. Although cardiovascular adverse events occurred at low frequencies in the two placebo-controlled clinical trials involving patients with moderate to severe Alzheimer's disease, there were increased frequencies of hypertension, ches pain, bradycardia and cardiac failure adverse events in patients who were treated with EBIXA ${ }^{\circ}$ compare to placebo in these trials. Consequently, caution should be observed when memantine is initiated in patients with cardiovascular conditions.

PRECAUTIONS: OPTHALMIC CONDITIONS: In an open label study where EBIXA ${ }^{\circ}$ was administered to 10 elderly patients at a dose of $20 \mathrm{mg} /$ day for approximately 48 months, memantine concentrations i lacrimal fluid were about 3 fold higher than in plasma and did not show ophthalmologic effects. another 6-month placebo-controlled trial, no major treatment differences were reported for ocular effects

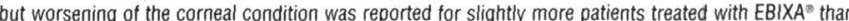
placebo ( $5.4 \%$ memantine vs. $3.3 \%$ placebo). Repeat-dose toxicology studies demonstrated corneal an lens histopathological changes in rodents treated with EBIXA ${ }^{*}$. Therefore, periodic monitoring of the patient's ophthalmic condition is recommended. CONCOMITANT USE WITH OTHER DRUGS: Use with compounds chemically related to $N$-methyl-D-aspartate (NMDA) antagonists: As these compounds act the same receptor system as memantine, adverse drug reactions (mainly CNS-related) may be more frequent or pronounced. Pharmacotoxic psychosis has been reported in the literature in two Parkinson's disease patients who were treated concomitantly with memantine, amantadine, L-dopa and terguride (see PRECAUTIONS, Drug Interactions, Other agents). The combined use of EBIXA* with other compound chemically related to NMDA antagonists such as amantadine, ketamine or dextromethorphan has not been systematically evaluated and is therefore not recommended. DRUGS THAT MAKE URINE ALKALINE: The clearance of memantine was reduced by about $80 \%$ under alkaline urine conditions at $\mathrm{pH} 8$. Therefore, alterations of urine $\mathrm{pH}$ towards the alkaline condition may lead to an accumulation of the drug with a possible increase in adverse effects. Urine pH is altered by diet, drugs (e.g. carbonic anhydrase inhibitors, sodium bicarbonate) and clinical state of the patient (e.g. renal tubular acidosis or sever infections of the urinary tract). Hence, memantine should be used with caution under these conditions (see ACTION AND CLINICAL PHARMACOLOGY and WARNINGS). SPECIAL POPULATIONS: HEPATIC IMPAIRMENT: The pharmacokinetics or pharmacodynamic effects of EBIXA' have not been studied in patients with hepatic impairment. As EBIXA ${ }^{\circ}$ undergoes minimal hepatic metabolism and is excrete primarily in its unchanged form by the kidneys, the pharmacokinetics of memantine would be expected to be only modestly affected. No adjustment in dosage is therefore recommended in hepatically impaired patients. RENAL IMPAIRMENT: There are limited data available from clinical trials for patients with mild to moderate renal impairment. In patients with normal to mildly impaired renal function (creatinine clearance $>60 \mathrm{ml} / \mathrm{min} / 1.73 \mathrm{~m}^{2}$ ) no dose reduction is needed. In patients with moderate renal impairment clearance $>60 \mathrm{ml} / \mathrm{min} / 1.73 \mathrm{~m}^{2}$ ) no dose reduction is needed. In patients with moderate renal impairment
(creatinine clearance $40-60 \mathrm{ml} / \mathrm{min} / 1.73 \mathrm{~m}^{2}$ ) daily dose should be reduced to $10 \mathrm{mg} /$ day. (see PHARMACOKINETICS). There are no data available in patients with severe renal impairment (creatinin clearance less than $9 \mathrm{ml} / \mathrm{min} / 1.73 \mathrm{~m}^{2}$ ), and the use of EBIXA⿱乛龰 in these patients is not recommended. (see ACTION AND CLINICAL PHARMACOLOGY and DOSAGE AND ADMINISTRATION). USE IN PATIENTS $\geq \mathbf{8 5}$ YEARS OLD: In placebo-controlled clinical studies, the number of patients aged 85 years or older who received memantine at the therapeutic dose of $20 \mathrm{mg} /$ day was 40 . There is limited safety information for EBIXA in this patient population. USE IN PATIENTS WITH SERIOUS CO-MORBID CONDITIONS: There is limited information on the safety of memantine treatment in patients with moderate to severe Alzheimer's disease with serious co-morbidities, as these patients were excluded from clinical trials. The use $\mathrm{EBIXA}^{\star}$ in Alzheimer's disease patients with chronic illnesses common among the geriatric population should be considered only after a proper risk/benefit assessment. Dose escalation in this patient population should proceed with caution. PREGNANCY: Oral treatment of female rats with memantine [ecommended Human Dose [MRHD] on a $\mathrm{mg} / \mathrm{m}^{2}$ basis); however memantine was no teratogenic at doses up to $18 \mathrm{mg} / \mathrm{kg} /$ day (9 times the MRHD on a mg/m $\mathrm{m}^{2}$ basis), the highest dose tested In a rat reproduction and fertility study, reduced growth and a developmental delay were observed a $18 \mathrm{mg} / \mathrm{kg} /$ day (9 times the MRHD on a mg/m $\mathrm{m}^{2}$ basis). Memantine doses of $0,3,10$ and $30 \mathrm{mg} / \mathrm{kg} / \mathrm{day}$ were orally administered to pregnant rabbits during the period of organogenesis. At $30 \mathrm{mg} / \mathrm{kg} / \mathrm{da}$ (30 times the MRHD on a $\mathrm{mg} / \mathrm{m}^{2}$ basis) maternal toxicity and a slight increase in post-implantation los were observed. No teratogenic effects were observed in rabbits administered memantine $30 \mathrm{mg} / \mathrm{kg} / \mathrm{day}$ (30 times the MRHD on a $\mathrm{mg} / \mathrm{m}^{2}$ basis). The maternal and fetal no observed effect level (NOEL) was $10 \mathrm{mg} / \mathrm{kg} /$ day (10 times the MRHD on a $\mathrm{mg} / \mathrm{m}^{2}$ basis). In a peri and postnatal study, memantine was orally administered in rats at up to $18 \mathrm{mg} / \mathrm{kg} /$ day (9 times the MRHD on a mg/m ${ }^{2}$ basis). At $18 \mathrm{mg} / \mathrm{kg} / \mathrm{da}$ pups showed reduced mean body weights but there was no effect on their development or behaviour. Animal studies showed no indication of an adverse effect of memantine on labor and delivery. There are no adequate and well-controlled studies of memantine in pregnant women to establish the safe use of EBIXA for this population. Therefore, EBIXA should not be used in women of childbearing potential unless, in the opinion of the physician, the expected benefits to the patient markedly outweigh the possible hazards to the foetus. NURSING MOTHERS: It is not known whether memantine is excreted in human breast milk. Therefore EBIXA ${ }^{*}$ should not be used in nursing mothers. PEDIATRIC USE: Th safety and effectiveness of EBIXA* in any illness occurring in pediatric patients has not been established Therefore, EBIXA ${ }^{B}$ is not recommended for use in children. DRUG INTERACTIONS: Effects of EBIXA substrates of microsomal enzymes: In vitro studies conducted with marker substrates of CYP450 enzymes (CYP1A2, -2A6, -2C9, -2D6, -2E1, -3A4) revealed minimal inhibition of these enzymes by memantine. No pharmacokinetic interactions with drugs metabolized by these enzymes are expected Effects of inhibitors and/or substrates of microsomal enzymes on EBIXA ${ }^{\star}$ : Memantine is predominantly renally eliminated, and drugs that are substrates and/or inhibitors of the CYP450 system are not expected to alter the metabolism of memantine. Acetylcholinesterase (AChE) inhibitors: In vitro studies have shown that memantine does not affect the reversible inhibition of acetylcholinesterase by donepezil or galantamine. In healthy adult volunteers, under steady-state conditions of the AChE inhibitor donepezil $\mathrm{HCl}$, coadministration of a single dose of EBIXA ${ }^{3}$ did not affect the pharmacokinetics of either compound and did not affect donepezil-mediated AChE inhibition. in a 24-week study of patients with moderate to severe Alzheimer's disease the adverse event profiles were similar for patients treated with a combination of memantine and donepezil or placebo and donepezil. The mechanism of action and pharmacokinetics of other AChE inhibitors (e.g. galantamine and rivastigmine) differ from donepezil and the safety of $\mathrm{CO}^{-}$ administration of these drugs with EBIXA ${ }^{*}$ has not been evaluated in clinical studies. Drugs eliminated via renal mechanisms: Co-administration of drugs that use the same renal cationic transport system as memantine, such as cimetidine, ranitidine, quinidine, hydrochlorothiazide ( $\mathrm{HCTZ}$ ), triamterene (TA), an nicotine could potentially alter the plasma levels of both agents. Coadministration of EBIXA ${ }^{\circ}$ and hydrochlorothiazide/triamterene (HCTZTA) did not affect the bioavailability of either memantine or triamterene, and the bioavailability of HCTZ decreased by $20 \%$. The pharmacokinetics of memantine is similar in smokers and non-smokers, suggesting that nicotine may not affect the disposition of memantine. Drugs highly bound to plasma proteins: Because the plasma protein binding of memantine is low $(45 \%)$, an interaction with drugs that are highly bound to plasma proteins, such as warfarin and digoxin, is unlikely. Other agents: Since the effects of L-dopa, dopaminergic agonists, and anticholinergics may be enhanced by concomitant treatment with EBIXA ${ }^{\circ}$, dosage adjustment of thes other agents may be necessary. CARCINOGENESIS, MUTAGENESIS AND IMPAIRMENT OF FERTILITY: There was no evidence of carcinogenicity in a 113-week oral study in mice for either sex at doses up to $40 \mathrm{mg} / \mathrm{kg} /$ day (10 times the maximum recommended human dose [MRHD] on a $\mathrm{mg} / \mathrm{m}^{2}$ basis). There was also no evidence of carcinogenicity in rats orally dosed at up to $40 \mathrm{mg} / \mathrm{kg} /$ day for 71 weeks followed by $20 \mathrm{mg} / \mathrm{kg} /$ day (19 and 10 times the MRHD on a $\mathrm{mg} / \mathrm{m}^{2}$ basis, respectively) through 128 weeks. Memantine did not show any genotoxic potential in assays for gene mutation (bacterial and mammalian cells in vitro) or in clastogenicity assays (human lymphocytes in vitro and mouse bone marrow in vivo). No impairment of fertility or reproductive performance was seen in rats administered up to $18 \mathrm{mg} / \mathrm{kg} / \mathrm{day}$ ( 9 times the MRHD on a $\mathrm{mg} / \mathrm{m}^{2}$ basis) orally from 14 days prior to mating through gestation and lactation in females, or for 60 days prior to mating in males. ADVERSE EVENTS: A total of 738 patients were treated with memantine in double-blind, placebo-controlled dementia studies. Of these patients, 592 $(80 \%)$ completed the studies. Patients were treated with memantine for a mean of 150.3 days. Approximately $60 \%$ of patients received memantine for at least 24 weeks. Adverse Events Leading to Discontinuation of Treatment: In placebo-controlled trials in which dementia patients received doses of EBIXA ${ }^{\circ}$ up to $20 \mathrm{mg} /$ day, $10.8 \%(80 / 738)$ of the EBIXA'-treated patients discontinued treatment due to an adverse event. The discontinuation rate in the placebo-treated patients was $11.2 \%(81 / 721)$. The most frequent adverse event leading to discontinuation was agitation with an observed frequency among patients who discontinued treatment of $1.2 \%$ in patients receiving memantine vs. $2.1 \%$ in patients administered placebo. None of the other adverse events leading to discontinuation met the criteria for most common adverse events, defined as those occurring at a frequency of at least $2 \%$ and at twice the incidence seen in placebo patients. Adverse Events Reported in Placebo-Controlled Dementia Trials: Table 1 lists treatment emergent signs and symptoms that were reported in at least $2 \%$ of patients in placebo-controlled dementia trials and for which the rate of occurrence was greater for patients treate with EBIXA ${ }^{*}$ than for those treated with placebo. The prescriber should be aware that these figures canno be used to predict the incidence of adverse events in the course of usual medical practice where patien characteristics and other factors differ from those that prevailed in the clinical trials. Similarly, the citer frequencies cannot be compared with figures obtained from other clinical investigations involving different treatments, uses, and investigators. The cited figures, however, do provide the prescribing physician with some basis for estimating the relative contribution of drug and non-drug factors to the adverse event incidence rate in the population studied.

Table 1: Adverse Events Reported in Controlled Clinical Trials in at Least $2 \%$ of Patients Receiving EBIXA and at a Higher Frequency than Placebo-treated Patients

\begin{tabular}{|c|c|c|}
\hline Body System & \multicolumn{2}{|c|}{$\%$} \\
\hline Adverse Event & Placebo $(\mathrm{N}=721)$ & EBIXA $^{*}(\mathrm{~N}=738)$ \\
\hline Body as a Whole & 0.7 & 2.3 \\
\hline Fatigue & 1.0 & 2.4 \\
\hline Pain & & 3.3 \\
\hline Cardiovascular System & 2.4 & 6.9 \\
\hline Hypertension & & 5.6 \\
\hline Central and Peripheral Nervous System & 4.6 & 6.1 \\
\hline Dizziness & 3.6 & 2.8 \\
\hline Headache & 3.5 & 3.0 \\
\hline Gastrointestinal System & 2.4 & 2.7 \\
\hline Constipation & 2.1 & \\
\hline Nausea & & 2.2 \\
\hline Vomiting & 2.5 & 2.6 \\
\hline Musculoskeletal System & & 5.7 \\
\hline Back pain & 1.2 & 2.6 \\
\hline Psychiatric Disorders & 0.8 & 2.8 \\
\hline Anorexia & 5.5 & 2.3 \\
\hline Anxiety & 1.2 & \\
\hline Confusion & 2.2 & \\
\hline Hallucinations & & \\
\hline Somnolence & 1.2 & \\
\hline Respiratory System & & \\
\hline Dyspnea & & \\
\hline
\end{tabular}


Other adverse events occurring with an incidence of at least $2 \%$ in EBIXA ${ }^{\star}$-treated patients but at an equal or lower rate than placebo were agitation, arthralgia, bronchitis, cataract, coughing, depression, diarrhea fall, gait abnormal, inflicted injury, influenza-like symptoms, insomnia, urinary incontinence and urinary tract infection. Vital Sign Changes: EBIXA ${ }^{\circ}$ and placebo groups were compared with respect to (1) mean change from baseline in vital signs (pulse, systolic blood pressure, and diastolic blood pressure) and (2) the incidence of patients meeting criteria for potentially clinically significant changes from baseline in these variables. These analyses did not reveal any clinically important changes in vital signs associated with EBIXA ${ }^{\circ}$ treatment

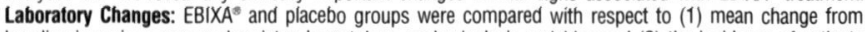
baseline in various serum chemistry, hematology, and urinalysis variables and (2) the incidence of patients meeting criteria for potentially clinically significant changes from baseline in these variables. These analyses revealed no clinically important changes in laboratory test parameters associated with EBIXA ${ }^{\star}$ treatment. ECG Changes: EBIXA and placebo groups were compared with respect to (1) mean change from baseline in various ECG parameters and (2) the incidence of patients meeting criteria for potentially clinically significant changes from baseline in these variables. These analyses revealed no clinically important changes in ECG parameters associated with EBIXA ${ }^{\circ}$ treatment. Adverse Events Observed in Placebo-Controlled Trial in Patients Previously Treated with Donepezil: In an additional double-blind, placebo-controlled study, 202 patients who had been treated with donepezil for at least 6 months and who had been on stable doses of donepezil for 3 months prior to randomization were treated with memantine for a period of 24 weeks while still receiving donepezil. Of these patients, $172(85 \%)$ completed the study. In this clinical trial, a total of $14.9 \%$ (30/202) of the memantine/donepezil patients discontinued the study compared to $25.4 \%$ (51/201) of the placebo/donepezil patients. The most frequent reason for discontinuation was adverse events and included $12 \%$ of placebo/donepezil patients and $7 \%$ of memantine/donepezil patients. Overall, the safety profile of the memantine/donepezil treated patients was similar to the one observed for the placebo-controlled dementia trials. The adverse events leading to discontinuation of the treatment, and for which the incidence was greater in the memantine/donepezil than in the placebo/donepezil group were: asthenia (memantine 1.0\%; placebo $0 \%$ ) dehydration (memantine 1.5\%; placebo $0 \%$ ) and confusion (memantine $2.0 \%$; placebo $1.5 \%$ ). Table 2 lists treatment emergent signs and symptoms that were reported in at least $2 \%$ of patients in placebocontrolled dementia trials and for which the rate of occurrence was greater for patients treated with EBIXA\%/donepezil than for those treated with placebo/donepezil.

Table 2: Adverse Events Reported in Controlled Clinical Trials in at Least 2\% of Patients Receiving EBIXA\%/donepezil and at a Higher Frequency than Placebo/donepezil-treated Patients

\begin{tabular}{|c|c|c|}
\hline Body System & ( & $\%$ \\
\hline Adverse Event & Placebo/donepezil ( $\mathrm{N}=201)$ & EBIXA $\%$ /donepezil ( $\mathrm{N}=202$ ) \\
\hline \multicolumn{3}{|l|}{ Body as a Whole } \\
\hline Chest pain & 0.0 & 2.5 \\
\hline Fall & 7.0 & 7.4 \\
\hline Fever & 0.5 & 2.0 \\
\hline Oedema peripheral & 4.0 & 5.0 \\
\hline Pain & 0.5 & 3.0 \\
\hline \multicolumn{3}{|l|}{ Cardiovascular System } \\
\hline Hypertension & 1.5 & 4.5 \\
\hline \multicolumn{3}{|c|}{ Central and Peripheral Nervous System } \\
\hline Gait abnormal & 1.0 & 3.0 \\
\hline Headache & 2.5 & 6.4 \\
\hline \multicolumn{3}{|l|}{ Gastrointestinal System } \\
\hline Constipation & 1.5 & 3.0 \\
\hline Vomiting & 3.0 & 3.5 \\
\hline \multicolumn{3}{|c|}{ Metabolic and Nutritional Disorders } \\
\hline Weight increase & 0.0 & 2.5 \\
\hline \multicolumn{3}{|l|}{ Musculoskeletal System } \\
\hline Arthralgia & 1.5 & 2.5 \\
\hline \multicolumn{3}{|l|}{ Psychiatric Disorders } \\
\hline Confusion & 2.0 & 7.9 \\
\hline Depression & 3.0 & 4.0 \\
\hline \multicolumn{3}{|l|}{ Red Blood Cell Disorder } \\
\hline Anemia & 0.5 & 2.0 \\
\hline \multicolumn{3}{|l|}{ Reproductive Disorders, Male } \\
\hline Prostatic disorder & 0.0 & 4.1 \\
\hline \multicolumn{3}{|l|}{ Respiratory System } \\
\hline Coughing & 1.0 & 3.0 \\
\hline Influenza-like symptoms & 6.5 & 7.4 \\
\hline \multicolumn{3}{|c|}{ Skin and Appendages Disorders } \\
\hline Rash & 1.5 & 2.5 \\
\hline \multicolumn{3}{|l|}{ Urinary System Disorders } \\
\hline Urinary tract infection & 5.0 & 5.9 \\
\hline Urinary incontinence & 3.0 & 5.4 \\
\hline Micturition frequency & 0.5 & 2.0 \\
\hline
\end{tabular}

in $2 \%$ of $E B I X A^{*} /$ donepezil treated patients (but less than $9 \%$ ) were abdominal pain, agitation, anorexy, anxiety, asthenia, back pain, bronchitis, dehydration, diarrhea, dizziness, fatigue, fecal incontinence, hallucinations, inflicted injury, insomnia, personality disorder, somnolence, syncope, tremor, upper respiratory tract infection. Other Adverse Events Observed During Clinical Trials: EBIXA has been administered to approximately 1150 patients with dementia, of whom more than 1000 received the maximum recommended dose of $20 \mathrm{mg} /$ day. Approximately 739 of whom more than 1000 received the maximum recommended dose of $20 \mathrm{mg}$ /day. Approximately 739 patients received EBIXA for at least 6 months of treatment and 387 patients were treated for approximately a
year or more. All adverse events occurring in at least two patients are included. except for those already listed year or more. All adverse events occurring in at least two patients are included, except for those already listed
in Tables 1 and 2, WHO terms too general to be informative, or events unlikely to be caused by the drug. Also included are the adverse events observed in the placebo-controlled trial in patients who had been previously treated with donepezil prior to EBIXA ${ }^{\star}$ treatment. Events are classified by body system and listed using the following definitions: frequent - those occurring on one or more occasions in at least 1/100 patients infrequent - those occurring in less than 1/100 patients but at least in 1/1000 patients. These adverse events are not necessarily related to EBIXA* treatment and in most cases were observed at a similar frequency in placebo-treated patients in the controlled studies. Autonomic Nervous System: Infrequent: sweating increased, mouth dry. Body as a Whole: Frequent: asthenia, oedema, leg pain, malaise, sepsis, syncope. Infrequent: abscess, allergic reaction, allergy, chest pain precordial, choking, condition aggravated, ESR Infrequent: abscess, allergic reaction, allergy, chest pain precordial, choking, condition aggravated, ESR increased, flushing, hernia NOS, hot flushes, hypothermia, infection, infection fungal, infection viral, moniliasis,
oedema peripheral, pallor. rigors, sudden death. Cardiovascular System: Frequent: angina pectoris, oedema peripheral, pallor, rigors, sudden death. Cardiovascular System: Frequent: angina pectoris,
bradycardia, cardiac failure, cardiac failure left, heart murmur, oedema dependent. Infrequent: aneurysm, arrhythmia, cardiac arrest, embolism pulmonary, fibrillation atrial, heart block, heart disorder, hypertension aggravated, hypotension, hypotension postural, myocardial infarction, palpitation, phlebitis, pulmonar oedema, tachychardia, thrombophlebitis, thrombophlebitis deep, vascular disorder. Central and Peripheral Nervous System: Frequent: aphasia, ataxia, cerebrovascular disorder, hypokinesia, transient ischemic attack, vertigo. Infrequent: absences, cerebral hemorrhage, coma, convulsions, coordination abnormal, extrapyramidal disorder, hemiparesis, hemiplegia, hyperkinesia, hypertonia, hypoesthesia, muscle contractions involuntary, neuralgia, neuropathy, paralysis, paresthesia, ptosis, speech disorder, stupor, tremor Gastrointestinal System: Frequent: abdominal pain, dyspepsia, fecal incontinence, hemorrhoids, tooth disorder. Infrequent: diverticulitis, dysphagia, esophageal ulceration, esophagitis, flatulence, gastroenteritis, disorder. Infrequent: diverticulitis, dysphagia, esophageal ulceration, esophagitis, flatulence, gastroenteritis, gastroesophageal reflux, gastrointestinal disorder NOS, Gl hemorrhage, gingivitis, hemorrhage rectum,
melena, mucositis NOS, oesophagitis, saliva altered, saliva increased, stomatitis ulcerative, tooth ache, tooth melena, mucositis NOS, oesophagitis, saliva altered, saliva increased, stomatitis ulcerative, tooth ache, tooth
caries. Hemic and Lymphatic Disorders: Frequent: purpura. Infrequent: epistaxis, hematoma, leukocytosis, leukopenia, polycythemia. Metabolic and Nutritional Disorders: Frequent: hyperglycemia, hypernatremia, hypokalemia, phosphatase alkaline increased, weight decrease. Infrequent: bilirubinemia, BUN increased dehydration, diabetes mellitus, diabetes mellitus aggravated, gamma-GT increased, gout, hepatic enzymes increased, hepatic function abnormal, hypercholesterolemia, hyperkalemia, hyperuricemia, hyponatremia, NPN increased, polydipsia, AST increased, ALT increased, thirst. Musculoskeletal System: Frequent: arthritis, arthrosis, muscle weakness, myalgia Infrequent arthritis aggravated, arthritis rheumatoid, bursitis, skeletal pain. Neoplasms: Intrequent: basal cell carcinoma, breast neoplasm benign (female) breast neoplasm malignant (female), carcinoma, neoplasm NOS, skin neoplasm malignant. Psychiatric Disorders: Frequent: aggressive reaction, apathy, cognitive disorder, delusion, nervousness. Infrequent: amnesia, appetite increased, concentration impaired, crying abnormal, delirium, depersonalization, emotional lability, libido increased, neurosis, paranoid reaction, paroniria, personality disorder, psychosis, sleep disorder, suicide attempt, thinking abnormal. Reproductive Disorders, Female: Infrequent: vaginal hemorrhage, moniliasis; Male: Frequent: moniliasis. Respiratory System: Frequent: pharyngitis, pneumonia, upper respiratory tract infection, rhinitis Infrequent apnea asthma bronchospasm, hemoptysis, respiratory disorder, sinusitis Skin cellulitis, dermatitis, eczema, pruritus, rash erythematous, seborrhea, skin dry, skin reaction localized, urticaria. Special Senses: Frequent: cataract, conjunctivitis, eye abnormality, macula lutea degeneration, vision abnormal. Infrequent: blepharitis, blurred vision, conjunctival hemorrhage, corneal opacity, decreased visual acuity, diplopia, ear ache, ear disorder NOS, eye infection, eye pain, glaucoma, hearing decreased, lacrimation abnormal, myopia, xerophthalmia, retinal detachment, retinal disorder, retinal hemorrhage, tinnitus. Urinary System: Frequent: cystitis, dysuria. Infrequent: hematuria, micturition disorder, polyuria, pyuria, renal function abnormal, urinary retention. Adverse Events From Other Sources: Memantine has been commercially available in Europe since 1982, and has been evaluated in clinical trials including patients with neuropathic pain. Parkinson's disease, organic brain syndrome, and spasticity. Although no causal relationship to memantine treatment has been found the following adverse events have been reported to be temporally associated with memantine treatment in more than one patient and are not described elsewhere in labeling: acne, bone fracture, carpal tunnel syndrome, claudication, hyperlipidemia, impotence, otitis media, thrombocytopenia.

SYMPTOMS AND TREATMENT OF OVERDOSAGE: SYMPTOMS: In a documented case of an overdosage with up to $400 \mathrm{mg}$ memantine, the patient experienced restlessness, psychosis, visual hallucinations, proconvulsiveness, somnolence, stupor and loss of consciousness. The patient recovered without permanent sequelae. TREATMENT OF OVERDOSAGE: Because strategies for the management of overdose are continually evolving, it is advisable to contact a poison control center to determine the latest recommendations for the management of an overdose of any drug. Establish and maintain an airway to ensure adequate ventilation and oxygenation. Gastric lavage and use of activated charcoal should be considered. Cardiac and vital sign monitoring are recommended, along with general symptomatic and supportive measures. There are no specific antidotes for EBIXA ${ }^{\circ}$. Elimination of memantine can be enhanced by acidification of urine.

DOSAGE AND ADMINISTRATION: EBIXA ${ }^{\circledR}$ (memantine hydrochloride) should only be prescribed by (or following consultation with) clinicians who are experienced in the diagnosis and management of Alzheimer's disease. Therapy should only be started if a caregiver is available who will regularly monitor drug intake by the patient. Diagnosis should be made according to current guidelines. Adults: The recommended maintenance by upward titration as follows: the usual starting dose is $5 \mathrm{mg} /$ day. The dose should then be increased in $5 \mathrm{mg}$ increments to $10 \mathrm{mg} /$ day ( $5 \mathrm{mg}$ twice a day). $15 \mathrm{mg} / \mathrm{day}$ ( $10 \mathrm{mg}$ and $5 \mathrm{mg}$ as separate doses), and $20 \mathrm{mg} /$ day (ncrements to $10 \mathrm{mg} / \mathrm{day}$ ( $5 \mathrm{mg}$ twice a day), $15 \mathrm{mg} / \mathrm{day}(10 \mathrm{mg}$ and $5 \mathrm{mg}$ as separate doses), and $20 \mathrm{mg} / \mathrm{day}$ between dose increases is one week. The recommended dose titration is summarized in the following table.

\begin{tabular}{|lcc|}
\hline \multicolumn{3}{|c|}{$\mathbf{1 0} \mathbf{~ m g}$ Tablets } \\
\hline Aeek 1 & AM & PM \\
\hline Week 2 & $1 / 2$ tablet & None \\
\hline Week 3 & $1 / 2$ tablet & $1 / 2$ tablet \\
\hline Week 4 and beyond & 1 tablet & $1 / 2$ tablet \\
\hline
\end{tabular}

\section{The tablets can be taken with or without food.}

DOSES IN SPECIAL POPULATIONS: Elderly On the basis of the clinical studies the recommended dose for patients over the age of 65 years is $20 \mathrm{mg} /$ day $(10 \mathrm{mg}$ twice a day) as described above (see PHARAMCOKINETICS) Renal impairment. In patients with normal to mildly impaired renal function (creatinine clearance $>60 \mathrm{ml} / \mathrm{min} / 1.73 \mathrm{~m}^{2}$ ) no dose reduction is needed. In patients with moderate renal impairment (creatinine clearance $40-60 \mathrm{ml} / \mathrm{min} / 1.73 \mathrm{~m}^{2}$ ) daily dose should be reduced to $10 \mathrm{mg} /$ day. In patients with severe renal impairment the use of EBIXA ${ }^{\odot}$ has not been systematically evaluated and is therefore not recommended in these patients (See PHARMACOKINETICS and PRECAUTIONS). Hepatic impairment. There are no data on the use of memantine in patients with hepatic impairment (see PHARMACOKINETICS and PRECAUTIONS). No adjustment in dosage is recommended in hepatically impaired patients.

\section{PHARMACEUTICAL INFORMATION:}

DRUG SUBSTANCE:

Common Name: Memantine hydrochlorid

Code Name: MEM3; D145; MRZ 2/145

Chemical Name: 1-amino-3,5-dimethyladamantane hydrochloride.

Structural Formula:<smiles>CC12CC3(C)CC(C)(C1)CC(N)(C2)C3</smiles>

Molecular Formula: $\mathrm{C}_{12} \mathrm{H}_{22} \mathrm{Cl} \mathrm{N}$

Molecular Weight: 215.77 (hydrochloride) 179.31 (base)

Description: White, crystalline, practically odourless powder

$\mathrm{pH}: 5.5-6.0$

pKa: 10.27

Solubility: water, hydrochloridic acid, methanol, n-hexane (soluble), methylene chloride, chloroform (freely soluble), ethylacetate (practically insoluble)

Partition Coefficient: Log P (n-octanol/water): 3.28

Composition: EBIXA* tablets contain $10 \mathrm{mg}$ of memantine hydrochloride and the following non-medicinal ingredients: lactose monohydrate, microcrystalline cellulose, colloidal anhydrous silica, talc, magnesium stearate, methacrylic acid-ethyl acrylate copolymer, sodium lauryl sulphate, polysorbate 80 , triacetin, simethicone emulsion.

Stability and Storage Recommendations: EBIXA tablets should be stored in a dry place at room temperature between $15^{\circ}$ and $30^{\circ} \mathrm{C}$

AVAILABILITY OF DOSAGE FORMS: EBIXA (memantine hydrochloride) is available as white to off-white tablets.

$10 \mathrm{mg}$ tablets: White to off-white, centrally tapered oblong, biconvex, film-coated tablet with a single break line on both sides. Blister packages of 30 tablets.

Product Monograph available to Healthcare professionals upon request.

Lundbeck Canada Inc.

413 St-Jacques Street West, Suite FB-230

Montreal (Quebec), Canada H2Y 1 N9

Registered trademark of Merz Pharm GmbH. Under license to Lundbeck Canada Inc. 


\section{AVONEX \\ (Interferon beta-1a)}

\section{PRESCRIBING INFORMATION THERAPEUTIC CLASSIFICATION}

\section{INDICATIONS AND CLINICAL USE}

\section{Relapsing Forms of Multiple Sclerosis:}

AVONEX (Interferon beta-1a) is indicated for the treatment of relapsing forms of multiple sclerosis (MS) to slow the progression of disability, decrease the frequency of clinical exacerbations, and reduce the number and volume of active brain lesions identified on Magnetic Resonance Imaging (MRI) scans.

\section{Single Demyelinating Event:}

AVONEX ${ }^{\mathbb{B}}$ is also indicated for the treatment of people who have experienced a single demyelinating event, accompanied by abnormal Magnetic Resonance Imaging (MRI) scans with lesions typical of MS, to delay the onset of clinically definite multiple sclerosis (as determined by a second demyelinating event) and to decrease the number and volume of active brain lesions and overal disease burden (as identified by MRI scans). Before initiating treatment with AVONEX, alternate diagnoses should first be excluded.

Safety and efficacy have not been evaluated in patients with chronic progressive multiple sclerosis.

\section{CONTRAINDICATIONS}

AVONEX ( hypersensitivity to natural or recombinant interferon beta, hurnan albumin, or any other component of the formulation

\section{WARNINGS}

AVONEX should be used under the supervision of a physician. The firs injection should be performed under the supervision of an appropriately qualified health care professional (see DOSAGE AND ADMINISTRATION)

\section{Depression and Suicide}

AVONEX (Interferon beta-1a) should be used with caution in patients with depression. Depression and suicide have been reported to occur in patients receiving other interferon compounds. Depression and suicidal ideation are known to occur at an increased frequency in the MS population. A relationship between the occurrence of depression and/or suicidal ideation and the use of AVONEX has not been established. An equal incidence of depression was seen in the placebo-treated and the AVONEX ${ }^{\circledast}$-treated patients in the placebo controlled study of relapsing MS patients. In the study of patients with a single demyelinating event AVONEX ${ }^{8}$-treated patients were more likely to experience depression than placebo-treated patients $(p=0.05)$. Suicidal tendency occurred in one subject treated with placebo, and there were no reports of suicide attempts. Patients treated with AVONEX should be advised to report immediately any symptoms of depression and/or suicidal ideation to their prescribing physicians. If a patient develops depression, antidepressant therapy or cessation of AVONEX therapy should be considered

\section{Anaphylaxis}

Anaphylaxis has been reported as a rare complication of AVONEX use. Othe allergic reactions have included dyspnea, orolingual edema, skin rash and urticaria (see ADVERSE EVENTS)

\section{Decreased Peripheral Blood Counts}

Decreased peripheral blood counts in all cell lines, including very rare pancytopenia and thrombocytopenia have been reported from post-marketing experience (see ADVERSE EVENTS). Some cases of thrombocytopenia have had nadirs below 10,000/uL. Some cases reoccur with re-challenge. Patients should be monitored for signs of these disorders (see PRECAUTIONS: Laboratory Tests).

\section{Pregnancy and Lactation}

AVONEX should not be administered in case of pregnancy and lactation. There are no adequate and well-controlled studies of AVONEX ${ }^{\circledR}$ in pregnant women. Patients should be advised of the abortifacient potential of AVONEX Fertile women receiving AVONEX should be advised to take adequate contraceptive measures. It is not known if interferons alter the efficacy of oral contraceptives (see PRECAUTIONS: Information to Patients).

If a woman becomes pregnant or plans to become pregnant while taking AVONEX ${ }^{B}$, she should be informed of the potential hazards to the fetus, and it should be recommended that the woman discontinue therapy. The reproductive toxicity of AVONEX has not been studied in animals or humans. In pregnant monkeys given interferon beta at 100 times the recommended weekly human dose (based upon a body surface area comparison), no teratogenic or other adverse effects on fetal development were observed. Abortifacient activity was evident following 3 to 5 doses at this level. No abortifacient effects were observed in monkeys treated at 2 times the recommended weekly human dose (based upon a body surface area comparison). Although no teratogenic effects were seen in these studies, it is not known if teratogenic effects would be observed in humans. There are no adequate and well-controlled studies with interferons in pregnant women.

\section{Nursing Mother}

It is not known whether AVONEX is excreted in human milk. Because of the potential of serious adverse reactions in nursing infants, a decision should be made to either discontinue nursing or to discontinue AVONEX

\section{PRECAUTIONS}

\section{General}

Patients should be informed of the most common adverse events associated with interferon beta administration, including symptoms of the flu-like syndrome (see ADVERSE EVENTS). These symptoms tend to be most prominent at the initiation of therapy and decrease in frequency and severity with continued treatment (see PRECAUTIONS: Information to Patients)

\section{Seizures}

Caution should be exercised when administering AVONEX (Interferon beta-1a) to patients with pre-existing seizure disorder. In the two placebo-controlled studies of MS, 4 patients receiving AVONEX experienced seizures, while no seizures occurred in the placebo group. Of these 4 patients, 3 had no prior history of seizure. It is not known whether these events were related to the effect of MS alone, to AVONEX ${ }^{\circledR}$, or to a combination of both. For patients with no prior history of seizure who developed seizures during therapy with AVONEX an etiologic basis should be established and appropriate anti-convulsan therapy instituted prior to considering resumption of AVONEX treatment. The effect of AVONEX ${ }^{\circledR}$ administration on the medical management of patients with seizure disorder is unknown.

\section{Cardiac Disease}

Patients with cardiac disease, such as angina, congestive heart failure, or arrhythmia, should be closely monitored for worsening of their clinica condition during initiation and continued treatment with AVONEX ${ }^{\circledR}$. While AVONEX ${ }^{\circledast}$ does not have any known direct-acting cardiac toxicity, during the post-marketing period infrequent cases of congestive heart failure, cardiomyopathy, and cardiomyopathy with congestive heart failure have been reported in patients without known predisposition to these events or othe known etiologies. In rare cases, these events have been temporally related the administration of $A V O N E X^{\circledR}$ and have recurred upon re-challenge in patients with known predisposition.

Autoimmune Disorders

As with other interferon treatment, autoimmune disorders of multiple target organs have been reported post marketing including idiopathic thrombocytopenia, hyper and hypothyroidism, and rare cases of autoimmune hepatitis have also been reported. Patients should be monitored for signs of these disorders (see PRECAUTIONS: Laboratory Tests) and appropriate treatment implemented when observed.

\section{Hepatic Injury}

AVONEX ${ }^{\circledast}$, like other interferon beta products, has the potential for causing severe liver injury (see ADVERSE EVENTS). Hepatic injury including elevated serum hepatic enzyme levels and hepatitis, some of which have been severe, has been reported post-marketing. In some patients a recurrence of elevated serum levels of hepatic enzymes have occurred upon AVONEX re-challenge. In some cases, these events have occurred in the presence of other drugs that have been associated with hepatic injury. The potential of additive effects from multiple drugs or other hepatotoxic agents (e.g., alcohol) has not been determined. Patients should be monitored for signs of hepatic injury (see PRECAUTIONS: Laboratory Tests) and caution exercised when AVONEX is used concomitantly with other drugs associated with hepatic injury.

\section{Laboratory Tests}

Laboratory abnormalities are associated with the use of interferons. During the placebo-controlled trials in multiple sclerosis, liver function tests were performed at least every 6 months. Liver function tests including serum AL are recommended during AVONEX therapy and should be performed a baseline, monthly at months 1 through 6 , and every 6 months thereafte AVONEX ${ }^{8}$ should be initiated with caution in patients with a history of significant liver disease, clinical evidence of active liver disease, alcoho abuse, increased serum ALT (>2.5 times ULN), and in patients receiving concomitant medications associated with hepatic injury. These patients may require more frequent monitoring of serum hepatic enzymes. Discontinuation or interruption of AVONEX ${ }^{\circledast}$ should be considered if ALT rises above 5 times the ULN. Treatment with AVONEX should be stopped if jaundice or othe clinical symptoms of liver dysfunction appear. In addition to those laboratory tests normally required for monitoring patients with MS, and in addition to liver enzyme monitoring (see PRECAUTIONS: Hepatic Injury) complete blood cell counts and white blood cell differential, platelet counts, and blood chemistries, including thyroid function tests, are recommended during AVONEX therapy (see WARNINGS: Decreased Peripheral Blood Counts and ADVERSE EVENTS). These tests should be performed at baseline months $1,3,6$, and every 6 months thereafter. Patients with myelosuppression may require more intensive monitoring of complete blood cell counts, with differential and platelet counts.

\section{Immunogenicity}

Serum neutralizing antibodies were reported to develop in only $2 \%$ to $6 \%$ of AVONEX -treated patients. Although the exact clinical significance of antibodies has not been fully established, there are multiple literature reports indicating that the occurrence of neutralizing antibodies with beta interferon treatment impacts clinical efficacy, MRI measures and the induction of biological markers.

\section{Drug Interactions}

No formal drug interaction studies have been conducted with AVONEX ${ }^{\circledR}$. In the placebo-controlled study, corticosteroids or ACTH were administered for treatment of exacerbations in some patients concurrently receiving AVONEX In addition, some patients receiving AVONEX ${ }^{\circledR}$ were also treated with anti-depressant therapy and/or oral contraceptive therapy. No unexpected adverse events were associated with these concomitant therapies.

Other interferons have been noted to reduce cytochrome $\mathrm{P}-450$ oxidase-mediated drug metabolism. Formal hepatic drug metabolism studies with AVONEX in humans have not been conducted. Hepatic microsomes isolated from AVONEX-treated rhesus monkeys showed no influence of AVONEX ${ }^{\circledR}$ on hepatic P-450 enzyme metabolism activity.

As with all interferon products, proper monitoring of patients is required if AVONEX $X^{*}$ is given in combination with myelosuppressive agents.

\section{Carcinogenesis and Mutagenesis}

Carcinogenesis: No carcinogenicity data for Interferon beta-1a are available in animals or humans.

Mutagenesis: Interferon beta-1a was not mutagenic when tested in the Ames bacterial test and in an in vitro cytogenetic assay in human lymphocytes in the presence and absence of metabolic activation. These assays are designed to detect agents that interact directly with and cause damage to cellular DNA. Interferon beta-1a is a glycosylated protein that does not directly bind to DNA.

\section{Impairment of Fertility}

No studies were conducted to evaluate the effects of interferon beta on fertility in normal women or women with MS. It is not known whether AVONEX can affect human reproductive capacity. Menstrual irregularities were observed in monkeys administered interferon beta at a dose 100 times the recommended weekly human dose (based upon a body surface area comparison). Anovulation

and decreased serum progesterone levels were also noted transiently in some animals. These effects were reversible after discontinuation of drug. Treatment of monkeys with interferon beta at 2 times the recommended weekly human dose (based upon a body surface area comparison) had no effects on cycle duration or ovulation.

The accuracy of extrapolating animal doses to human doses is not known. In the placebo-controlled study, $6 \%$ of patients receiving placebo and 5\% of patients receiving AVONEX experienced menstrual disorder. If menstrua rregularities occur in humans, it is not known how long they will persist ollowing treatment.

\section{Pediatric Use}

Safety and effectiveness have not been established in pediatric patients below the age of 18 years.

\section{Information to Patients}

Patients should be informed of the most common adverse events associate with AVONEX administration, including symptoms associated with flu syndrome (see ADVERSE EVENTS

Symptoms of flu syndrome are most prominent at the initiation of therapy and decrease in frequency with continued treatment. In the placebo-controlled study, patients were instructed to take $650 \mathrm{mg}$ acetaminophen immediately prior to injection and for an additional 24 hours after each injection to modulate acute symptoms associated with AVONEX administration.

Patients should be advised not to stop or modify their treatment unless instructed by their physician.

Patients should be cautioned to report depression or suicidal ideation (see WARNINGS)

Patients should be informed about the risk of decreased blood counts including white blood cells and platelet counts and of the requirement for periodic laboratory testing (see WARNINGS). Patients should be advised to report immediately any clinical symptoms associated with blood count abnormalities and laboratory testing should be performed according to standard medical practice (see WARNINGS). Patients with myelosuppression may require more intensive monitoring of complete blood cell counts, with differential and platelet counts.

Patients should be informed of the potential risk of liver injury with AVONEX therapy, and of the requirement for frequent laboratory testing (see

PRECAUTIONS). Patients should be informed of the symptoms suggesting liver dysfunction, such as loss of appetite accompanied by other symptoms such as nausea, vomiting, and jaundice, and advised to consult with their physician immediately should such symptoms arise.

Patients should be instructed to report any symptoms of thyroid dysfunction (hypo or hyperthyroidism) and thyroid function tests should be performed according to standard medical practice (see PRECAUTIONS)

Female patients should be advised about the abortifacient potential of AVONEX and instructed to take adequate contraceptive measures (see PRECAUTIONS) When a physician determines that AVONEX ${ }^{\circledR}$ can be used outside of the physician's office, persons who will be administering AVONEX should receive instruction in reconstitution and injection, including the review of the injection procedures. If a patient is to self-administer, the physical ability of that patient to self-iniect intramuscularly should be assessed. It home use is chosen, the first injection should be performed under the supervision of a qualified health care professional. Patients should be advised of the importance of rotating sites of injection with each dose, to minimize the likelihood of injection site reactions. A puncture-resistant container for disposal of needles and syringes should be used. Patients should be instructed in the technique and importance of proper syringe and needle disposal and be cautioned against reuse of these items

\section{ADVERSE EVENTS}

\section{Relapsing Multiple Sclerosis}

The safety data describing the use of AVONEX (Interteron beta-1a) in MS patients are based on the placebo-controlled trial in which 158 patients with relapsing multiple sclerosis randomized to AVONEX ${ }^{\star}$ were treated for up to 2 years.

The 5 most common adverse events associated (at $p<0.075$ ) with AVONEX treatment were flu-like symptoms (otherwise unspecified), muscle ache, tever, chills, and asthenia. The incidence of all 5 adverse events diminished with continued treatment.

One patient in the placebo group attempted suicide; no AVONEX -treated patients attempted suicide. The incidence of depression was equal in the 2 treatment groups. However, since depression and suicide have been reported with other interferon products, AVONEX should be used with caution in patients with depression (see WARNINGS

In the placebo-controlled study, 4 patients receiving AVONEX experience seizures, while no seizures occurred in the placebo group. Of these 4 patients, 3 had no prior history of seizure. It is not known whether these events were related to the effects of MS alone, to AVONEX ${ }^{*}$, or to a combination of both (see PRECAUTIONS)

Table 1 enumerates adverse events and selected laboratory abnormalities that occurred at an incidence of $2 \%$ or more among the 158 patients with relapsing MS treated with $30 \mathrm{mcg}$ of AVONEX once weekly by IM injection. Reported adverse events have been classified using standard COSTART terms. Terms so general as to be uninformative or more common in the placebo-treated patients have been excluded 
BREFPESCRENG NFORMATON

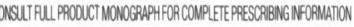

Reminyl

(a)

$4 \mathrm{mg} .8 \mathrm{mg} .12$ mggalantamine base

ReminylER

galantamine hydobromide extended release
$8 \mathrm{mg}, 16 \mathrm{mg}, 24 \mathrm{mg}$ galantamine base Choinesterase innibitor

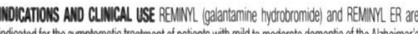

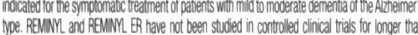
6 months. RER

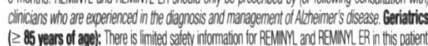

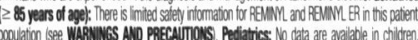

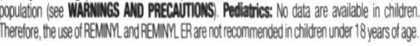

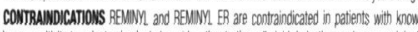

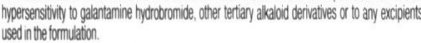
WARUWWGS ANO PRECCAUTOONS Carcinogenesesis and Mutagenesis See Product Monograph Part II: TOXXCOLOGY- Carcinogennicity, Mutagenicity for discussion on animal data

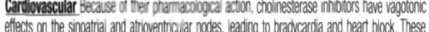

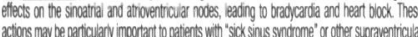

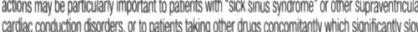

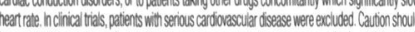

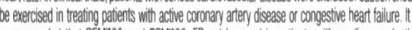

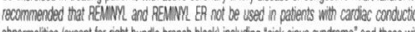

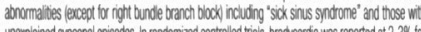

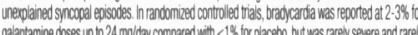

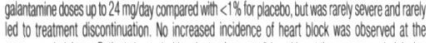

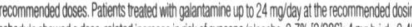

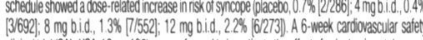

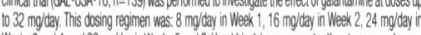

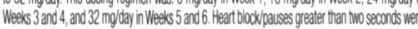

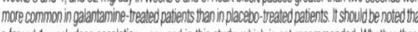
torod 1 - wex dose escalation was used in tis stury, which is not recormented Whether thes:

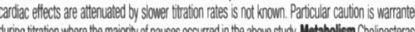

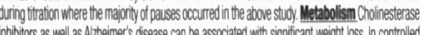

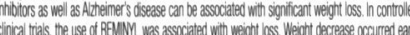

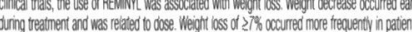

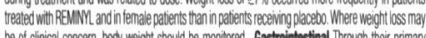

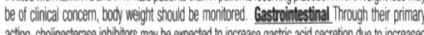

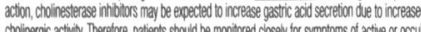

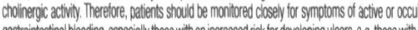

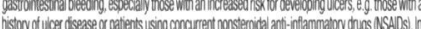

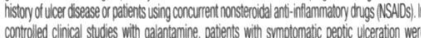

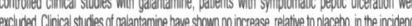

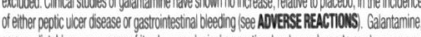

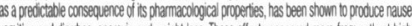

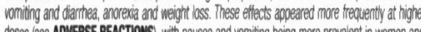

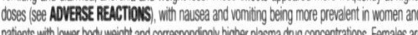

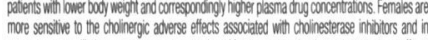

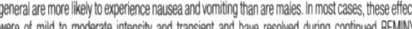

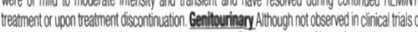

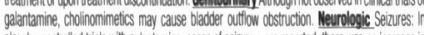

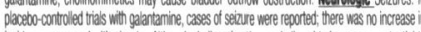

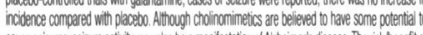

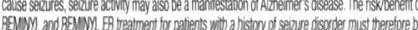

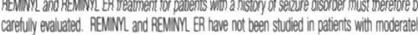

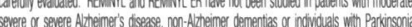

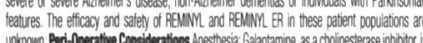

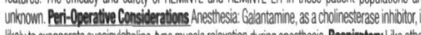

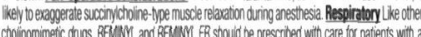

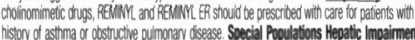

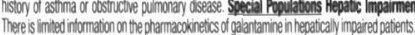

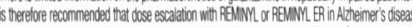

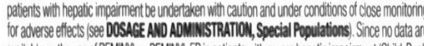

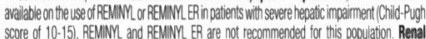

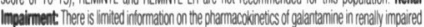

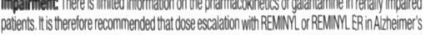

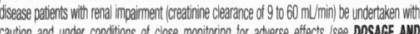

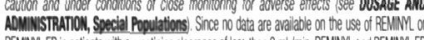

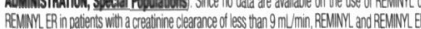

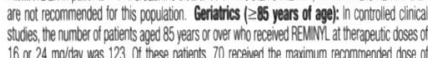

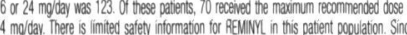

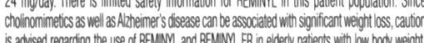
especialy in those $\geq 85$ vears ad. Lse in Eldery Patients with Serious Concotid Disease There linted intormation on the satery of galantamine treatment in patients with mild to moderate

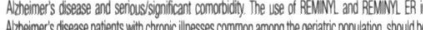

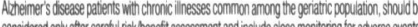
Dosse escalabon in this patert

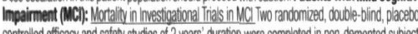

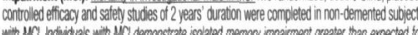

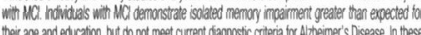

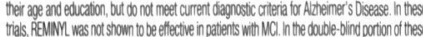

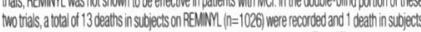

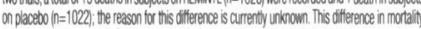

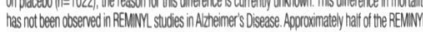

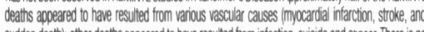

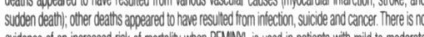

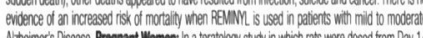

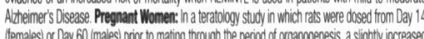

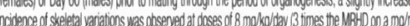

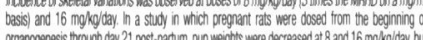

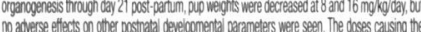

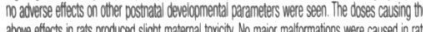

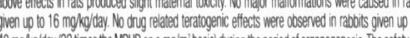

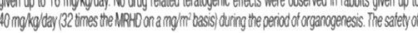

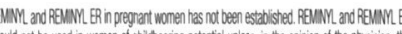

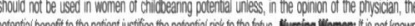

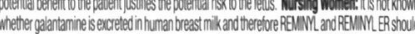

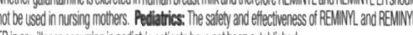
ADVEASE REACTONOS Clinical Trial Aoverse Onug Reactions Becouse cinica trias a

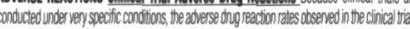
may not reflect the rates observed in pracico and stroud not be compared to the rates in the clinic

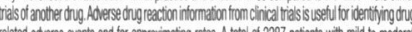

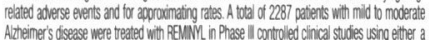

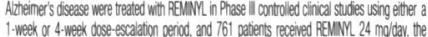

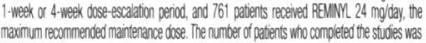

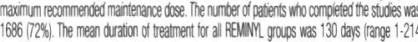

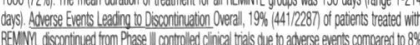

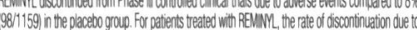

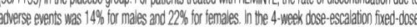

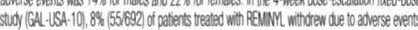

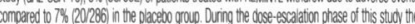

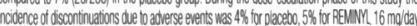

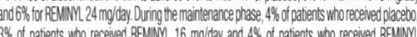

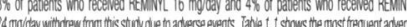

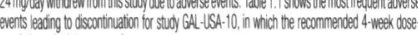
en schedje vas used.

Iable 1.: Most trequent adverse events leading to discontinuation in a placebo-

\begin{tabular}{|c|c|c|c|}
\hline \multirow[b]{2}{*}{ Aoverse Events } & \multicolumn{3}{|c|}{ Recommended 4 - week dose escalation } \\
\hline & Practo $n=286 \%$ & 16 modtay $n=279 \%$ & $24 m$ molay $n=273$ \% \\
\hline Neussea & $<1$ & 2 & 4 \\
\hline Vontrong & 0 & 1 & 3 \\
\hline Anorevia & $<$ & 1 & $<$ \\
\hline Diziness & $\langle 1$ & 2 & 1 \\
\hline Syrope & T & 0 & 1 \\
\hline
\end{tabular}

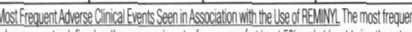

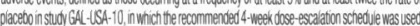

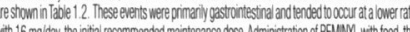

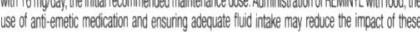
Table 1.2. Wost trequent atverse events in a randomized placebo-controlled cinical trial (GA- USA-10)

\begin{tabular}{|c|c|c|c|c|c|c|}
\hline & \multicolumn{3}{|c|}{ Week $1-12$} & \multicolumn{3}{|c|}{ Week $13-21$} \\
\hline Adverse & Practo & 16 mydday & 24 mydiay & Pacebo & \begin{tabular}{|l}
$16 \mathrm{my} y$ day \\
\end{tabular} & 24 mydda \\
\hline Events & $n=2868$ & $n=279 \%$ & $n=273 \%$ & $n=259 \%$ & $n=243 x$ & $n=241 \%$ \\
\hline Nausea & 5 & 11 & 13 & $<1$ & 4 & 6 \\
\hline Vomitiog & $<1$ & 5 & 6 & $<1$ & 2 & 6 \\
\hline Diarntea & 5 & 9 & 4 & 2 & 5 & 2 \\
\hline Anorexia & 2 & 5 & 5 & 1 & 2 & 5 \\
\hline
\end{tabular}

The majority of these adverse events sccurred during the cosse- escalation period. Nausea and

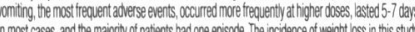

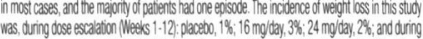

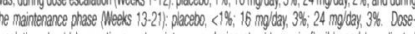

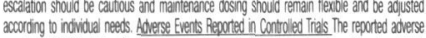

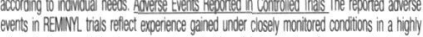

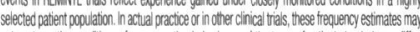

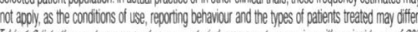

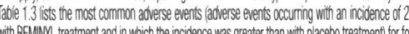

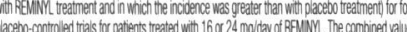

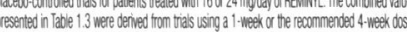
ssalaton period

Iable 1.3: Averese events reported in at least $2 \%$ of patients with Alzheimer's disease administered REMIIML and at a trequency greater than with placebo (combined 1- and week dose-escelation data

\begin{tabular}{|c|c|c|}
\hline Boty System/ Adverse Events & $\begin{array}{l}\text { Paraceno } \\
(n=801) \%\end{array}$ & $\begin{array}{l}\text { PEMMM } \\
(n=1040) \%\end{array}$ \\
\hline $\begin{array}{l}\text { Body as a whole - general disorders } \\
\text { Fatigue } \\
\text { Syncope }\end{array}$ & $\begin{array}{l}3 \\
1 \\
\end{array}$ & $\begin{array}{l}5 \\
2 \\
\end{array}$ \\
\hline $\begin{array}{l}\text { Central \& peripheral nervous systen disorders } \\
\text { Diziness } \\
\text { Headache }\end{array}$ & $\begin{array}{l}6 \\
5\end{array}$ & $\begin{array}{l}9 \\
8\end{array}$ \\
\hline
\end{tabular}

\begin{tabular}{|c|c|c|}
\hline Tremor & 2 & 3 \\
\hline 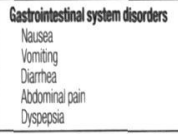 & $\begin{array}{l}9 \\
4 \\
7 \\
4 \\
2 \\
\end{array}$ & $\begin{array}{l}24 \\
13 \\
9 \\
5 \\
5 \\
\end{array}$ \\
\hline $\begin{array}{l}\text { Heartrate and hiththm disorders } \\
\text { Bradycarda }\end{array}$ & 1 & 2 \\
\hline $\begin{array}{l}\text { Metabolic and nutitional disorders } \\
\text { Weght decrease }\end{array}$ & 2 & 7 \\
\hline $\begin{array}{l}\text { Psychiatric disorders } \\
\text { Anorexia } \\
\text { Depression } \\
\text { Insomnia } \\
\text { Somndence }\end{array}$ & $\begin{array}{l}3 \\
5 \\
4 \\
3\end{array}$ & $\begin{array}{l}9 \\
7 \\
5 \\
4\end{array}$ \\
\hline
\end{tabular}

Red blood cell disorder

Respiratary ssstem disorders

\section{Urinary system disorders}

Uninary vract
Hematura

TAdverse events in patier

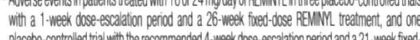
pacebo-Ontrolled tria with the reconn

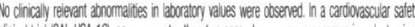

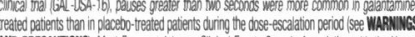

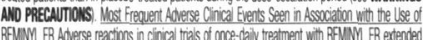

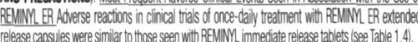
hed online by Cambridge University Press
Table 14: Adverse events reported in at least $2 \%$ of patients with Alzheimer's diseese

\begin{tabular}{|c|c|c|c|}
\hline $\begin{array}{l}\text { System Organ Class } \\
\text { Prefereed Term }\end{array}$ & $\begin{array}{l}\text { Placedo } \\
(n=320) \\
\%\end{array}$ & $\begin{array}{l}\text { REMNM } \\
(n=326) \\
\%\end{array}$ & $\begin{array}{c}\text { REUMMLER } \\
(n=319) \\
y\end{array}$ \\
\hline $\begin{array}{l}\text { Body as a whole - general disorders } \\
\text { inury } \\
\text { Edema peripherel } \\
\text { Fatove } \\
\text { Synoope } \\
\text { Fever } \\
\text { Legg pan }\end{array}$ & $\begin{array}{l}3 \\
1 \\
1 \\
1\end{array}$ & $\begin{array}{l}4 \\
2 \\
4 \\
1 \\
2 \\
2 \\
2\end{array}$ & $\begin{array}{l}8 \\
4 \\
4 \\
2 \\
1 \\
<1\end{array}$ \\
\hline $\begin{array}{l}\text { Central \& peripheral nervous } \\
\text { system disoriders } \\
\text { Diziness } \\
\text { Headache } \\
\text { Tremor }\end{array}$ & $\begin{array}{l}4 \\
6 \\
0 \\
\end{array}$ & $\begin{array}{l}7 \\
6 \\
1 \\
\end{array}$ & $\begin{array}{l}10 \\
8 \\
2 \\
\end{array}$ \\
\hline 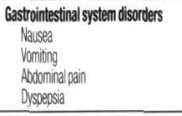 & $\begin{array}{l}5 \\
2 \\
2 \\
2 \\
\end{array}$ & $\begin{array}{c}14 \\
9 \\
3 \\
3 \\
\end{array}$ & $\begin{array}{l}17 \\
7 \\
2 \\
2 \\
\end{array}$ \\
\hline $\begin{array}{l}\text { Heart rate and hiththm disorders } \\
\text { Bracycardia }\end{array}$ & 2 & 2 & 3 \\
\hline $\begin{array}{l}\text { Metabolic and nutritional disorders } \\
\text { Weght deccease } \\
\text { Hppergyceriatia }\end{array}$ & 1 & $\begin{array}{l}5 \\
2 \\
\end{array}$ & $\begin{array}{l}4 \\
2 \\
\end{array}$ \\
\hline $\begin{array}{l}\text { Musculoskeletal system disorders } \\
\text { Atthriga } \\
\text { Skeitat pain } \\
\text { Aithritis } \\
\text { Magia }\end{array}$ & $\begin{array}{l}2 \\
1 \\
1\end{array}$ & $\begin{array}{l}2 \\
3 \\
1 \\
1 \\
\end{array}$ & $\begin{array}{l}3 \\
2 \\
2 \\
2 \\
\end{array}$ \\
\hline 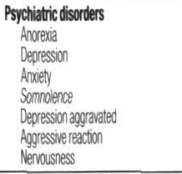 & $\begin{array}{l}3 \\
3 \\
3 \\
2 \\
1 \\
1 \\
1\end{array}$ & $\begin{array}{l}7 \\
5 \\
1 \\
2 \\
2 \\
2 \\
2 \\
2\end{array}$ & $\begin{array}{l}6 \\
6 \\
4 \\
3 \\
2 \\
2 \\
1\end{array}$ \\
\hline $\begin{array}{l}\text { Respiratory system disorders } \\
\text { Rhinits } \\
\text { Pneumoria }\end{array}$ & $\begin{array}{l}3 \\
1 \\
\end{array}$ & $\begin{array}{l}4 \\
2 \\
\end{array}$ & $\begin{array}{l}4 \\
2 \\
\end{array}$ \\
\hline $\begin{array}{l}\text { Secondary terms } \\
\text { Abrasion nos" }\end{array}$ & 1 & 1 & 2 \\
\hline $\begin{array}{l}\text { Skin and appendages disorders } \\
\text { Passt }\end{array}$ & 1 & $<1$ & 3 \\
\hline $\begin{array}{l}\text { Uninaryysytem disorders } \\
\text { Henaturia }\end{array}$ & 1 & 1 & 2 \\
\hline Micturitiontrequency & 1 & 2 & 1 \\
\hline $\begin{array}{l}\text { Vision disorters } \\
\text { Catract }\end{array}$ & 1 & 1 & 2 \\
\hline
\end{tabular}

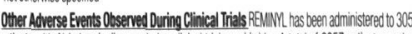

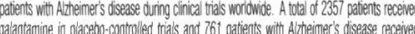

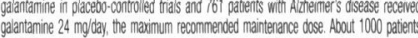

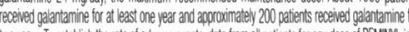

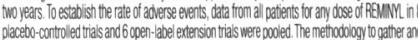

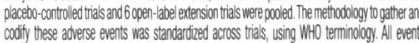

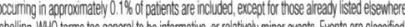

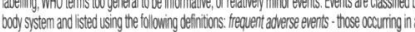

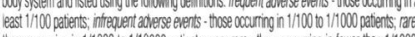

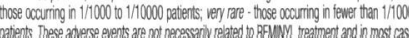

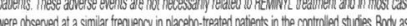

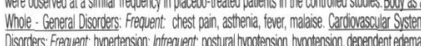

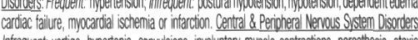

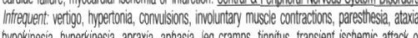

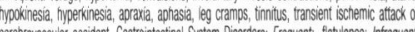

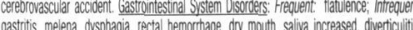

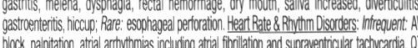

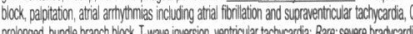

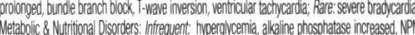

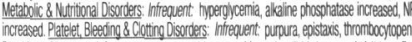

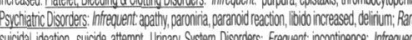

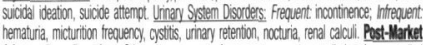

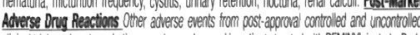

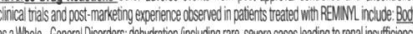

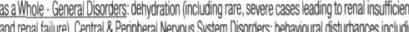

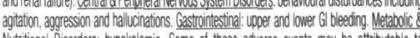

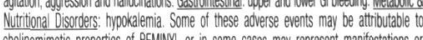
choinomimetic proderties of REMNYLL or in some cases may represent me

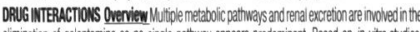

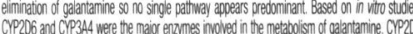

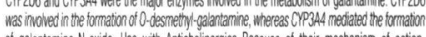

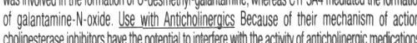

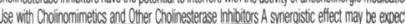

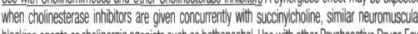

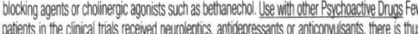

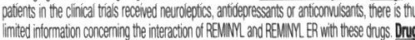

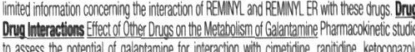

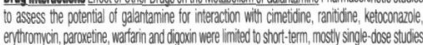

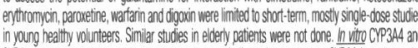

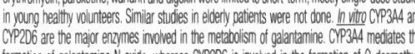

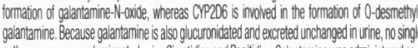

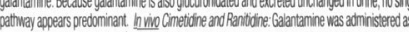

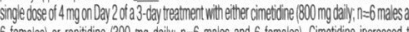

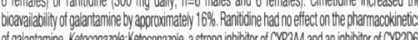

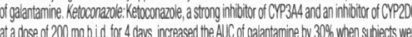

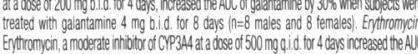

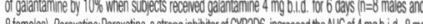

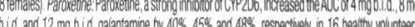

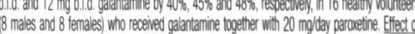

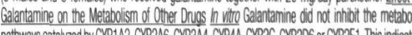

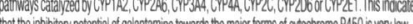

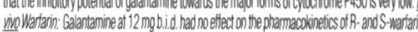

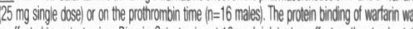

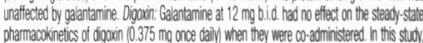

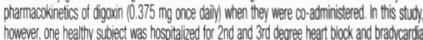

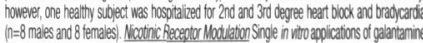

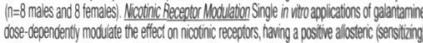

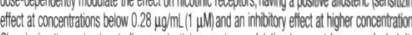

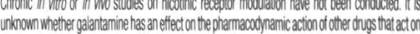

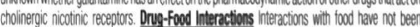

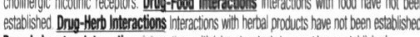

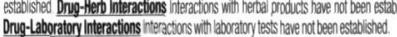

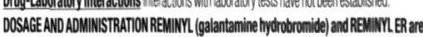

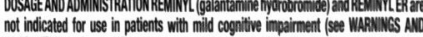
PRECAUTTONS, Special Populations, Patients with Wild Cognitive Impaiment (MCI)

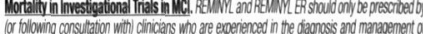

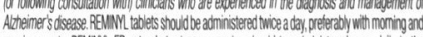

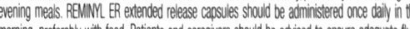

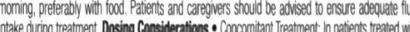

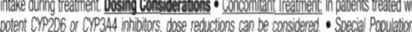

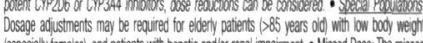

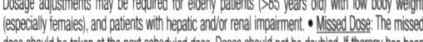

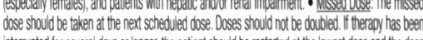

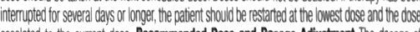

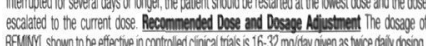

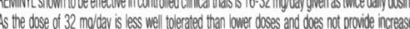

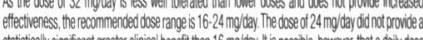

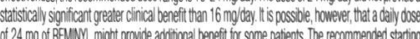

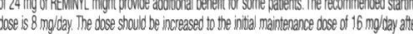

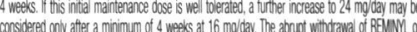

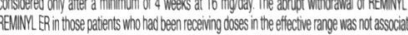

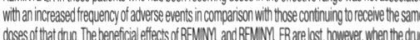

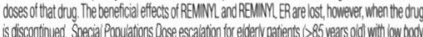

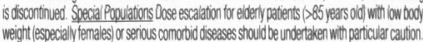

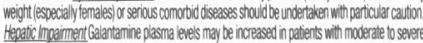

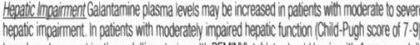

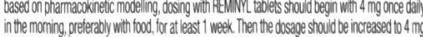

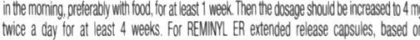

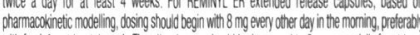

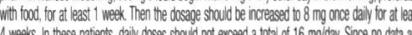

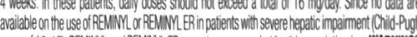

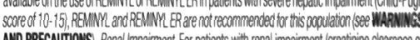

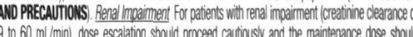

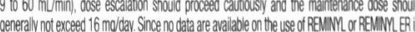

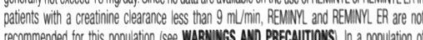

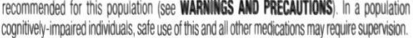

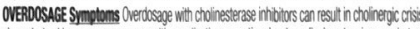

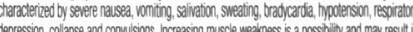

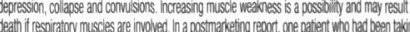

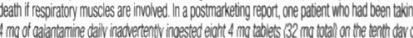

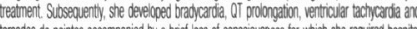

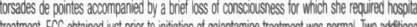

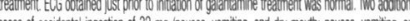

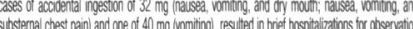

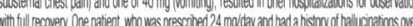

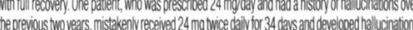

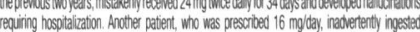

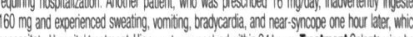

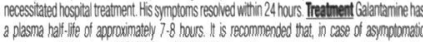

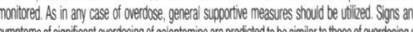
other cholinominetics. These effects generally involve the central nervous ssstem, the

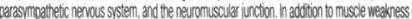

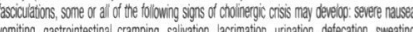

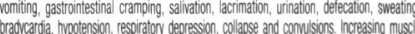

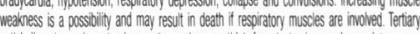

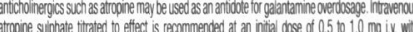

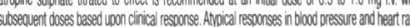
have been reported with other cholinomineics when co-doministered with quaternan

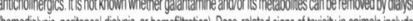

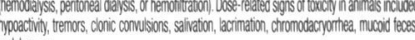
andossperea.

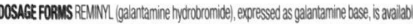

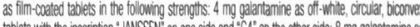

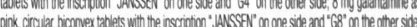

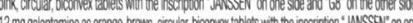

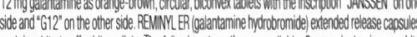
contain white to oft-white pellets. The tollowing strengths are avaichle: $8 \mathrm{mg}$ gaantanine as $\mathrm{m}$ -

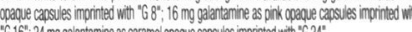




\section{"REQUIP}

Ropinirole (as ropinirole hydrochloride)

TABLETS: $0.25 \mathrm{mg}, 1.0 \mathrm{mg}, 2.0 \mathrm{mg}, 5.0 \mathrm{mg}$

THERAPEUTIC CLASSIFICATION: AntiParkinsonian Agent / Dopamine Agonist INDICATIONS AND CLINICAL USE: REQUIP" (ropinirole hydrochloride) is indicated in the treatment of the signs and symptoms of idiopathic Parkinson's disease. REQUIP ${ }^{\infty}$ can be used both as early therapy, without concomitant levodopa and as an adjunct to levodopa. Three year and five year activecomparator controlled clinical trials have been conducted.

CONTRAINDICATIONS: REQUIP® (ropinirole hydrochloride) is contraindicated in patients with a known hypersensitivity to ropinirole hydrochloride or the excipients of the drug product.

WARNINGS: Sudden Onset of Sleep - Patients receiving treatment with REQUIP ${ }^{s}$ (ropinirole hydrochloride), and other dopaminergic agents have reported suddenly falling asleep while engaged in activities of daily living, including operating a motor vehicle, which has sometimes resulted in accidents. Although some of the patients reported somnolence while on REQUIP" others perceived that they had no warning signs, such as excessive drowsiness, and believed that they were alert immediately prior to the event. Physicians should alert patients of the reported cases of sudden onset of sleep, bearing in mind that these events are NOT limited to initiation of therapy. Patients should also be advised that sudden onset of sleep has occurred without warning signs. If drowsiness or sudden onset of sleep should occur, patients should immediately contact their physician. Until further information is available on the management of this unpredictable and serious adverse event, patients should be warned not to drive or engage in other activities where impaired alertness could put themselves and others at risk of serious injury or death (e.g., operating machines). Episodes of falling asleep while engaged in activities of daily living have also been reported in patients taking other dopaminergic agents, therefore, symptoms may not be alleviated by substituting these products. Presently, the precise cause of this event is unknown. It is known that many Parkinson's disease patients experience alterations in sleep architecture, which results in excessive daytime sleepiness or spontaneous dozing, and that dopaminergic agents can also induce sleepiness. There is insufficient information to determine whether this event is associated with REQUIP , all dopaminergic agents or Parkinson's disease itself. Orthostatic Symptoms - Dopamine agonists appear to impair the systemic regulation of blood pressure with resulting orthostatic symptoms of dizziness or lightheadedness, with or without documented hypotension. These symptoms appear to occur especially during dose escalation. Therefore, patients treated with dopamine agonists should be carefully monitored for signs and symptoms of orthostatic hypotension, especially during dose escalation (see DOSAGE and ADMINISTRATION) and should be informed of this risk. Hallucinations - Early Therapy: In placebo- controlled trials, REQUIPo (ropinirole hydrochloride) caused hallucination in $5.1 \%$ of patients during early therapy (1.4\% in the placebo group). Hallucination was of sufficient severity that it led to discontinuation in $1.3 \%$ of patients. The incidence of hallucination was dose-dependent. In a 5-year study comparing REQUIP with levodopa in early Parkinson's patients, the overall incidence of hallucinations was $17.3 \%$ (31/179) for patients treated with REQUIP ${ }^{8}$ and $5.6 \%(5 / 89)$ for levodopa patients. Hallucinations led to discontinuation of the study treatment in $5.0 \%$ of REQUIP ${ }^{8}$ and $2.2 \%$ of levodopa patients. in a 3-year study comparing REQUIP with another dopamine agonist, the overall incidence of hallucinations was $9.5 \%$ (16/168) for patients treated with REQUIP® and $9.0 \%$ (15/167) for patients receiving active comparator. Hallucinations led to discontinuation of the study treatment in $2.4 \%$ of REQUIP ${ }^{*}$ patients and $3.0 \%$ of comparator patients. Concomitant Selegiline: In a 5-year study, REQUIPo patients receiving concomitant selegiline reported a higher incidence of hallucinations $(23.5 \%)$ than did those without (12.2\%); this subpopulation effect was not seen in the L-dopa arm (hallucinations with concomitant selegiline $=2.0 \%$ vs hallucinations without selegiline $=8.0 \%$ ). Adjunct Therapy: Hallucinations were experienced by $10.1 \%$ of patients receiving REQUIP ${ }^{\infty}$ and levodopa, compared to $4.2 \%$ receiving placebo and levodopa. Hallucinations were of sufficient severity that it led to discontinuation in $1.9 \%$ of patients. The incidence of hallucinations was dose dependent

PRECAUTIONS: Cardiovascular - Since REQUIP® (ropinirole hydrochloride) has not been studied in patients with a history or evidence of significant cardiovascular disease including myocardial infarction, unstable angina, cardiac decompensation, cardiac arrhythmias, vaso-occlusive disease (including cerebral) or cardiomyopathy, it should be used with caution in such patients. There is limited experience with REQUIP in patients treated with antihypertensive and antiarrhythmic agents. Consequently, in such patients, the dose of REQUIPø should be titrated with caution. Orthostatic Symptoms Orthostatic symptoms of dizziness or lightheadedness as well as somnolence may occur during REQUIP" therapy. Neuroleptic Malignant Syndrome - A symptom complex resembling the neuroleptic malignant syndrome (characterized by elevated temperature, muscular rigidity, altered consciousness, and autonomic instability), with no other obvious etiology, has been reported in association with rapid dose reduction, withdrawal of, or changes in anti-Parkinsonian therapy. A single spontaneous report of a symptom complex resembling the neuroleptic malignant syndrome has been observed in a 66 year old diabetic male patient with Parkinson's disease, who developed fever, muscle stiffness, and drowsiness 8 days after beginning REQUIP ${ }^{\circledast}$ treatment. The patient also experienced acute bronchitis, which did not respond to antibiotic treatment. REQUIP ${ }^{\$}$ was discontinued three days before the patient died. The reporting physician considered these events to be possibly related to REQUIPo treatment. (see DOSAGE AND ADMINISTRATION). A single spontaneous report of severe muscle pain has been reported in a 66 year old male patient around his thigh. The reporting physician considered the event to be probably related to REQUIP® treatment. Retinal Pathology in Rats - In a two year carcinogenicity study in albino Sprague-Dawley rats, retinal atrophy was observed at incidences of $0 \%, 1.4 \%, 1.4 \%$ and $10 \%$ of male rats and $0 \%, 4.4 \%, 2.9 \%$ and $12.9 \%$ of female rats dosed at $0,1.5,15$ and $50 \mathrm{mg} / \mathrm{kg} /$ day respectively. The incidence was significantly higher in both male and female animals dosed at $50 \mathrm{mg} / \mathrm{kg} / \mathrm{day}$. The $50 \mathrm{mg} / \mathrm{kg} /$ day dose represents a 2.8 fold greater exposure (AUC) and a 13.1 fold greater exposure $\left(C_{\max }\right)$ to ropinirole in rats than the exposure would be in humans at the maximum recommended dose of $24 \mathrm{mg} /$ day. The relevance of this finding to humans is not known. Pregnancy - The use of REQUIP during pregnancy is not recommended. REQUIP given to pregnant rats during organogenesis (gestation days 8 through 15) resulted in decreased fetal body weight at $60 \mathrm{mg} / \mathrm{kg} /$ day (approximately 3-4 times the AUC at the maximal human dose of $8 \mathrm{mg}$ t.i.d.), increased fetal death at $90 \mathrm{mg} / \mathrm{kg} / \mathrm{day}$ (approximately 5 times the AUC at the maximal human dose of $8 \mathrm{mg}$ t.i.d.) and digital malformations at $150 \mathrm{mg} / \mathrm{kg} /$ day (approximately 8-9 times the AUC at the maximal human dose of $8 \mathrm{mg}$ t.i.d.). These effects occurred at maternally toxic doses. There was no indication of an effect on development of the conceptus at a maternally toxic dose of $20 \mathrm{mg} / \mathrm{kg} /$ day in the rabbit. In a perinatal-postnatal study in rats, $10 \mathrm{mg} / \mathrm{kg} /$ day of REQUIP® (approximately $0.5-0.6$ times the AUC at the maximal human dose of $8 \mathrm{mg}$ t.i.d.) impaired growth and development of nursing offspring and altered neurological development of female offspring. Nursing Mothers - Since REQUIP suppresses lactation, it should not be administered to mothers who wish to breast-feed infants. Studies in rats have shown that REQUIP and/or its metabolites cross the placenta and are excreted in breast milk. Consequently, the human fetus and/or neonate may be exposed to dopamine agonist activity. Use in Women Receiving Estrogen Replacement Therapy- In female patients on long-term treatment with conjugated estrogens, oral clearance was reduced and elimination half-life prolonged compared to patients not receiving estrogens. In patients, already receiving estrogen replacement therapy, REQUIP ${ }^{\circledast}$ may be titrated in the recommended manner according to clinical response. However, if estrogen replacement therapy is stopped or introduced during treatment with REQUIP adjustment of the REQUIPe dosage may be required. Pediatric Use - Safety and effectiveness in the pediatric population have not been established. Renal and Hepatic Impairment - No dosage adjustment is needed in patients with mild to moderate renal impairment (creatinine clearance of 30 to $50 \mathrm{~mL} / \mathrm{min}$ ). Because the use of REQUIP in patients with severe renal impairment or hepatic impairment has not been studied, administration of REQUIP' to such patients is not recommended. Drug Interactions - Psychotropic Drugs: Neuroleptics and other centrally active dopamine antagonists may diminish the effectiveness of REQUIP ${ }^{\circledast}$. Therefore, concomitant use of these products is not recommended. Based on population pharmacokinetic assessment, no interaction was seen between REQUIP ${ }^{\star}$ and tricyclic antidepressants or benzodiazepines. Anti-Parkinson Drugs: Based on population pharmacokinetic assessment, there were no interactions between REQUIP ${ }^{*}$ and drugs commonly used to treat Parkinson's disease, i.e., selegiline, amantadine, and anticholinergics. Levodopa: The potential pharmacokinetic interaction of levodopa/ carbidopa (100 mg/10 mg b.i.d.) and REQUIPक ( $2 \mathrm{mg}$ t.i.d.) was assessed in levodopa naive (de novo) male and female patients with Parkinson's disease ( $n=30$, mean age 64 years). The rate and extent of availability of REQUIP\$ at steady state were essentially the same with or without levodopa. Similarly, the rate and extent of availability of levodopa, as well as its elimination half-life, were essentially the same in the presence and absence of REQUIP\$. Inhibitors of CYP1A2: Ciprofloxacin: The effect of ciprofloxacin (500 $\mathrm{mg}$ b.i.d.) on the pharmacokinetics of REQUIP® $(2 \mathrm{mg}$ t.i.d.) was studied in male and female patients with Parkinson's disease $(n=12$ mean age 55 years). The extent of systemic availability of REQUIP ${ }^{\circledast}$ was significantly increased when coadministered with ciprofloxacin (AUC increased by 1.84 fold). Thus, in patients already receiving CYP1A2 inhibitors such as ciprofloxacin, REQUIPs therapy may be instituted in the recommended manner and the dose titrated according to clinical response. However, if therapy with a drug known to be an inhibitor of CYP1A2 is stopped or introduced during treatment with REQUIPक adjustment of the REQUIP® dosage will be required Substrates of CYP1A2: Theophylline: The effect of oral theophylline $(300 \mathrm{mg}$ b.i.d.) on the pharmacokinetics of REQUIP ${ }^{\infty}(2 \mathrm{mg}$ t.i.d.) was studied in male and female patients with Parkinson's disease ( $n=12$, mean age 59 years) There was no marked change in the rate or extent of availability of REQUIP ${ }^{\infty}$ when coadministered with theophylline. Similarly, coadministration of REQUIP with intravenous theophylline $(5 \mathrm{mg} / \mathrm{kg})$ did not result in any marked change in the pharmacokinetics of theophylline. It is therefore unlikely that substrates of CYP1A2 would significantly alter the pharmacokinetics of REQUIP ${ }^{\infty}$, and vice-versa. Digoxin: The effect of REQUIP» (2 mg ti.i.) on the pharmacokinetics of digoxin $(0.125-0.25 \mathrm{mg}$ 0.d) was studied in male and female patients with Parkinson's disease ( $n=10$, mean age 72 years). Coadministration at steady state with REQUIP ${ }^{\circledast}$ resulted in a $10 \%$ decrease in digoxin AUC although mean trough digoxin plasma concentrations were unaltered. However, the effect of higher recommended doses of REQUIP® on the pharmacokinetics of digoxin is not known. Alcohol: No information is available on the potential for interaction between REQUIP" and alcohol. As with other centrally active medications, patients should be cautioned against taking REQUIP with alcohol. Psycho-Motor Performance - (see WARNINGSSudden Onset of Sleep).

ADVERSE REACTIONS: Adverse Reactions Associated with Discontinuation of Treatment - Of 1599 patients who received REQUIP (ropinirole hydrochloride) during the premarketing clinical trials, $17.1 \%$ in early-therapy studies and $17.3 \%$ in adjunct-therapy studies discontinued treatment due to adverse reactions. The events resulting in discontinuation of REQUIP in $1 \%$ or more of patients were as follows: Early therapy: nausea $(6.4 \%)$, dizziness (3.8\%), aggravated Parkinson's disease (1.3\%), hallucination $(1.3 \%)$, headache $(1.3 \%)$, somnolence $(1.3 \%)$ and vomiting $(1.3 \%)$. Adjunct therapy: dizziness $(2.9 \%)$, dyskinesia $(2.4 \%)$, confusion $(2.4 \%)$, vomiting $(2.4 \%)$, hallucination $(1.9 \%)$, nausea $(1.9 \%)$, anxiety $(1.9 \%)$, and increased sweating (1.4\%). Patients over 75 years of age $(n=130)$ showed slightly higher incidences of withdrawal due to hallucination, confusion and dizziness than patients less than 75 years of age. Most Frequent Adverse Events - Adverse events occurring with an incidence of greater than, or equal to, $10 \%$ were as follows: Early therapy: nausea, dizziness, somnolence, headache, peripheral edema, vomiting, syncope, fatigue and viral infection. Adjunct therapy: dyskinesia, nausea, dizziness, somnolence and headache. Dopamine agonists, with an ergoline chemical structure have been associated with adverse experiences such as retroperitoneal fibrosis, erythromelalgia and pulmonary reactions. REQUIPs has a novel, non-ergoline chemical structure and no reports of such events have been observed in clinical trials. Incidence of Adverse Events in Placebo Controlled Trials - The incidence of postural hypotension, an event commonly associated with initiation of dopamine agonist therapy, was not notably different from placebo in clinical trials. However, decreases in systolic blood pressure to $<90 \mathrm{mmHg}$ have been observed in $13 \%$ (< $<5$ years), $16 \%$ ( $65-75$ years) and $7.6 \%$ ( $>75$ years) of patients treated with REQUIPe. Table 2 lists adverse events that occurred at an incidence of $1 \%$ or more among REQUIP ${ }^{\circ}$-treated patients who participated in placebo-controlled trials for up to one year. Patients were dosed in a range of $0.75 \mathrm{mg}$ to $24 \mathrm{mg} /$ day. Reported adverse events were classified using a standard World Health Organization (WHO)-based dictionary terminology. The prescriber should be aware that these figures can not be used to predict the incidence of adverse events in the course of usual medical practice where patient characteristics and other factors differ from those which prevailed in the clinical trials. Similarly, the cited frequencies can not be compared with figures obtained from other clinical investigations involving different treatments, uses and investigators. The cited figures, however, do provide the prescribing physician with some basis for estimating the relative contribution of drug and non-drug factors to the adverse events incidence rate in the population studied.

\begin{tabular}{|c|c|c|c|c|}
\hline \multicolumn{5}{|c|}{$\begin{array}{c}\text { TABLE 2 } \\
\text { Adverse events with incidence } 21 \% \text { from all placebo-controlled } \\
\text { early and adjunct therapy studies }\end{array}$} \\
\hline & \multicolumn{2}{|c|}{ Early Therapy } & \multicolumn{2}{|c|}{ Adjunct Therapy } \\
\hline & $\begin{array}{l}\text { REQUPP } \\
N=157 \\
\text { roccurrence }\end{array}$ & $\begin{array}{c}\text { Placebo } \\
\mathrm{N}=147 \\
\% \text { occurrence }\end{array}$ & $\begin{array}{c}\text { REQUIP } \\
N=208 \\
\% \text { occurrence }\end{array}$ & $\begin{array}{c}\text { Placebo } \\
N=120 \\
\% \text { occurrence }\end{array}$ \\
\hline \multicolumn{5}{|c|}{ Autonomic Nervous System } \\
\hline Sweating Increased & 6.4 & 4.1 & 7.2 & 1.7 \\
\hline Mouth Dry & 5.1 & 3.4 & 5.3 & 0.8 \\
\hline Flushing & 3.2 & 0.7 & 1.4 & 0.8 \\
\hline \multicolumn{5}{|l|}{ Body as a Whole General } \\
\hline Peripheral Edema & 13.4 & 4.1 & 3.9 & 2,5 \\
\hline Fatigue & 10.8 & 4.1 & $=$ & - \\
\hline Injury & - & - & 10.6 & 9.2 \\
\hline Pain & 7.6 & 4.1 & 5.3 & 3.3 \\
\hline Asthenia & 6.4 & 1.4 & - & - \\
\hline Drug Level Increased & 4.5 & 2.7 & 6.7 & 3.3 \\
\hline $\begin{array}{l}\text { Chest Pain } \\
\text { L }\end{array}$ & 3.8 & 2.0 & - & - \\
\hline Malaise & 3.2 & 0.7 & 1.4 & 0.8 \\
\hline \multicolumn{5}{|l|}{ Therapeutic Response } \\
\hline Decreased & 1.9 & 0.7 & - & - \\
\hline Cellulitis & 1.3 & 0.0 & - & - \\
\hline Influenza-like Symptoms & - & - & 1.0 & 0.0 \\
\hline Fever & - & - & 1.4 & 0.0 \\
\hline \multicolumn{5}{|l|}{ Cardiovascular General } \\
\hline Syncope & 11.5 & 1.4 & 2.9 & 1.7 \\
\hline Hypotension Postural & 6.4 & 4.8 & - & - \\
\hline Hypertension & 4.5 & 3.4 & 3.4 & 3.3 \\
\hline Hypotension & 1.9 & 0.0 & 2.4 & 0.8 \\
\hline Cardiac Failure & - & - & 1.0 & 0.0 \\
\hline \multicolumn{5}{|c|}{ Central and Peripheral Nervous System } \\
\hline Dizziness & 40.1 & 21.8 & 26.0 & 15.8 \\
\hline Dyskinesia & - & - & 33.7 & 12.5 \\
\hline Headache & 17.2 & 17.0 & 16.8 & 11.7 \\
\hline Ataxia (Falls) & - & - & 9.6 & 6.7 \\
\hline Tremor & - & - & 6.3 & 2.5 \\
\hline Paresthesia & - & - & 5.3 & 2.5 \\
\hline Hyperesthesia & 3.8 & 2.0 & - & - \\
\hline Dystonia & - & - & 4.3 & 4.2 \\
\hline Hypokinesia & - & - & 5.3 & 4.2 \\
\hline Paresis & - & - & 2.9 & 0.0 \\
\hline Speech Disorder & - & - & 1.0 & 0.0 \\
\hline Vertigo & 1.9 & 0.0 & - & - \\
\hline Carpal Tunnel Syndrome & 1.3 & 0.7 & - & - \\
\hline \multicolumn{5}{|l|}{ Gastrointestinal System } \\
\hline Nausea & 59.9 & 21.8 & 29.8 & 18.3 \\
\hline Vomiting & 12.1 & 6.8 & 7.2 & 4.2 \\
\hline Dyspepsia & 9.6 & 4.8 & - & - \\
\hline Constipation & 8.3 & 7.5 & 5.8 & 3.3 \\
\hline Abdominal Pain & 6.4 & 2.7 & $\begin{array}{l}8.0 \\
8.7\end{array}$ & 7.5 \\
\hline Diarrhea & - & - & 4.8 & 2.5 \\
\hline Anorexia & 3.8 & 1.4 & - & - \\
\hline Flatulence & 2.5 & 1.4 & 1.9 & 0.8 \\
\hline Tooth Disorder & 1.9 & 0.7 & 1.0 & 0.8 \\
\hline Saliva Increased & - & - & 2.4 & 0.8 \\
\hline Colitis & 1.3 & 0.0 & - & - \\
\hline Dysphagia & 1.3 & 0.0 & 2.4 & 0.8 \\
\hline Periodontitis & 1.3 & 0.0 & 1.4 & 0.8 \\
\hline Eructation & - & - & 1.4 & 0.0 \\
\hline Fecal Incontinence & - & - & 1.0 & 0.0 \\
\hline Hemorthoids & - & - & 1.0 & 0.0 \\
\hline Gastroesophageal Reflux & - & - & 1.0 & 0.0 \\
\hline Gastrointestinal Disorder (NOS) & S) - & - & 1.0 & 0.0 \\
\hline $\begin{array}{l}\text { Tooth Ache } \\
\text {. }\end{array}$ & - & - & 1.0 & 0.0 \\
\hline \multicolumn{5}{|l|}{ Hearing and Vestibular } \\
\hline Tinnitus & 1.3 & 0.0 & - & - \\
\hline \multicolumn{5}{|l|}{ Heart Rate and Rhythm } \\
\hline Palpitation & 3.2 & 2.0 & 2.9 & 2.5 \\
\hline
\end{tabular}




\begin{tabular}{|c|c|c|c|c|}
\hline & \multicolumn{2}{|c|}{ Earty Thereapy } & \multicolumn{2}{|c|}{ Mallunet Therapy } \\
\hline & 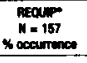 & 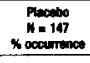 & 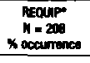 & 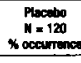 \\
\hline \multicolumn{5}{|l|}{ Heart Aate and Rhythm } \\
\hline Tachycardia & 1.9 & 0.0 & 1.0 & 0.0 \\
\hline Fibrillation Atrial & 1.9 & 0.0 & - & - \\
\hline Tachycardia Supraventricular & 1.3 & 0.0 & - & - \\
\hline Bradycardia & - & - & 1.0 & 0.0 \\
\hline \multicolumn{5}{|l|}{ Liver and Blltary System } \\
\hline Gamma - GT Increased & 1.3 & 0.7 & 1.0 & 0.0 \\
\hline Hepatic Enzymes Increased & 1.3 & 0.0 & - & - \\
\hline \multicolumn{5}{|l|}{ Metabolic and Nutrttlona: } \\
\hline Alkaline Phosphate Increased & 2.5 & 1.4 & 1.0 & 0.0 \\
\hline Weight Decrease & - & - & 2.4 & 0.8 \\
\hline Hypoglycemia & 1.3 & 0.0 & - & - \\
\hline \multicolumn{5}{|l|}{ Musculoskeletal Systom } \\
\hline Arthralgia & - & - & 6.7 & 5.0 \\
\hline Arthritis & - & - & 2.9 & 0.8 \\
\hline Arthritis Aggravated & 1.3 & 0.0 & 1.4 & 0.0 \\
\hline \multicolumn{5}{|c|}{ Myocardial, Endocardial, Pericardlal Valve } \\
\hline Myocardial ischemia & 1.3 & 0.7 & - & - \\
\hline \multicolumn{5}{|l|}{ Paychiatric } \\
\hline Somnolence & 40.1 & 6.1 & 20.2 & 8.3 \\
\hline Anxiety & - & - & 6.3 & 3.3 \\
\hline Confusion & 5.1 & 1.4 & 8.7 & 1.7 \\
\hline Hallucination & 5.1 & 1.4 & 10.1 & 4.2 \\
\hline Nervousness & - & - & 4.8 & 2.5 \\
\hline Yawning & 3.2 & 0.0 & - & - \\
\hline Amnesia & 2.5 & 1.4 & 4.8 & 0.8 \\
\hline Dreaming Abnormal & - & - & 2.9 & 1.7 \\
\hline Depersonalization & - & - & 1.4 & 0.0 \\
\hline Paranoid Reaction & - & - & 1.4 & 0.0 \\
\hline Agitation & 1.3 & 0.7 & 1.0 & 0.0 \\
\hline Concentration Impaired & 1.9 & 0.0 & 1.0 & 0.0 \\
\hline Husion & 1.3 & 0.0 & - & - \\
\hline Thinking Abnormal & - & - & 1.4 & 0.8 \\
\hline Apathy & - & - & 1.0 & 0.0 \\
\hline Increased Libido & - & - & 1.0 & 0.0 \\
\hline Personality Disorder & - & - & 1.0 & 0.0 \\
\hline \multicolumn{5}{|l|}{ Rod Blood Con } \\
\hline Reproductivo Malo & & & & \\
\hline Impotence & 2.5 & 1.4 & - & - \\
\hline Prostatic Disorder & - & - & 1.0 & 0.0 \\
\hline Penis Disorder & - & $=$ & 1.3 & 0.0 \\
\hline Fesistance Mechanism & & & & \\
\hline Upper flespiratory Tract infection & on - & - & 8.7 & 8.3 \\
\hline infection Viral & 10.8 & 3.4 & 7.2 & 6.7 \\
\hline Respirstory Systom & & & & \\
\hline Pharyngitis & 6.4 & 4.1 & - & - \\
\hline Phintits & 38 & 2.7 & - & - \\
\hline Sinusitivas & 3.8 & 2.7 & - & - \\
\hline Dyspnea & 3.2 & 0.0 & 2.9 & 1.7 \\
\hline Bronchitis & 2.5 & 1.4 & - & - \\
\hline Respiratory Oisorder & 1.9 & 1.4 & 1.9 & 0.0 \\
\hline Pneumonia & 1.3 & 0.7 & 1.0 & 0.8 \\
\hline Coughing & - & - & 1.4 & 0.8 \\
\hline Škin/Appendages & & & & \\
\hline Prurits & $=$ & - & 10 & 0.0 \\
\hline Urinsty System & & & & \\
\hline Urinary Tract Infection & 5.1 & 4.1 & 6.3 & 2.5 \\
\hline Cystitis & 1.3 & $\begin{array}{l}0.7 \\
-\end{array}$ & - & -0 \\
\hline Micturition Frequency & - & - & 1.4 & 0.0 \\
\hline Pyuria & - & - & 1.9 & 0.8 \\
\hline Urinary Incontinence & - & - & 1.9 & 0.8 \\
\hline Urinary Retention & 1.3 & 0.7 & - & - \\
\hline Dysuria & - & - & 1.0 & 0.0 \\
\hline $\begin{array}{l}\text { Vascular Extracardiac } \\
\text { Peripheral Ischemia }\end{array}$ & 2.5 & 0.0 & - & - \\
\hline Valon & & & & \\
\hline Vision Abnormal & 5.7 & 3.4 & - & - \\
\hline Eye Abnormality & 3.2 & 1.4 & - & - \\
\hline Diplopia & - & - & 1.9 & 0.8 \\
\hline Xerophthalmia & 1.9 & 0.0 & 1.4 & 0.8 \\
\hline Cataract & - & - & 1.4 & 0.8 \\
\hline Lacrimation Abnormal & - & - & 1.4 & 0.0 \\
\hline Whitio Cell and Reticuloendot & othellial Syste & & & \\
\hline Eosinophilia & - & - & 1.4 & 0.0 \\
\hline
\end{tabular}

a: Incidence of adverse event $<1 \%$

Post-Marketing Experience - Patients treated with REQUIP have rarely reported suddenly falling asleep while engaged in activities of daily living, including operation of motor vehicles which has sometimes resulted in accidents (see WARNINGS).

DOSAGE AND ADMINISTRATION: REQUIPo (ropinirole hydrochloride) should be taken three times daily. While administration of REQUIPo with meals may improve gastrointestinal tolerance, REQUIPo may be taken with or without food. The recommended starting dosage is $0.25 \mathrm{mg}$ three times daily. Based on individual patient response, dosage should then be titrated by weekly increments of $0.25 \mathrm{mg}$ per dose as described in the table below. After week 4 , daily dosage may be increased by 0.5 to $1.0 \mathrm{mg}$ per dose on a weekly basis until an optimal therapeutic response is established. Smaller dose increments are recommended for patients who may be at risk for orthostatic symptoms.

\begin{tabular}{|lcccc|}
\hline & \multicolumn{5}{c|}{ Week } \\
\hline & 1 & 2 & 3 & 4 \\
\hline Unit Dose (mg) & 0.25 & 0.5 & 0.75 & 1.0 \\
\hline Total Daily Dose (mg) & 0.75 & 1.5 & 2.25 & 3.0 \\
\hline
\end{tabular}

in clinical trials, initial benefits were observed with $3 \mathrm{mg} /$ day and higher doses. Doses greater than $24 \mathrm{mg} /$ day have not been included in clinical trials. In a 5 year, double-blind study of early therapy in Parkinson's disease patients, the average daily dose of REQUIPe (based on the observed data set) was $10.1 \mathrm{mg}$ at 6 months (median dose $=9.0 \mathrm{mg}$ ) $14.4 \mathrm{mg}$ at 3 years (median dose $=15.0$ $\mathrm{mg}$ ), and $16.6 \mathrm{mg}$ at 5 years (median dose $=18.0 \mathrm{mg}$ ), regardless of levodopa supplementation. When REQUIPo is administered as adjunct therapy to levodopa, the dose of levodopa may be decreased gradually as tolerated once a therapeutic effect with REQUIP has been observed. REOUIPos should be discontinued gradually over a 7-day period. The frequency of administration should be reduced from three times daily to twice daily for 4 days. For the remaining 3 days, the frequency should be reduced to once daily prior to complete withdrawal of REQUIP. Renal and Hepatic Impairment: In patients with mild to moderate renal impairment, REOUIPo may be titrated in the recommended manner according to clinical response. Patients with severe renal impairment or on hemodialysis have not been studied and administration of REQU.P to such patients is not recommended. Patients with hepatic impairment have not been studied and administration of REQUIPO to such patients is not recommended. Estrogen Replacement Therapy: In patients already receiving estrogen replacement therapy, REQUPP may be titrated in the recommended manner according to clinical response. However, if estrogen replacement therapy is stopped or started during treatment with REQUIP, adjustment of the REQUIPo dosage may be required. AVAILABIUTY of DOSAGE FORM: REQUIP is supplied as a pentagonal film-coated Tiltab tablet with beveled edges containing ropinirole (as ropinirole hydrochloride) as follows: $0.25 \mathrm{mg}$ - white imprinted with $\mathrm{SB}$ and $4890 ; 1.0 \mathrm{mg}$ - green imprinted with $\mathrm{SB}$ and 4892; $2.0 \mathrm{mg}$ - pale pink imprinted with $S B$ and $4893 ; 5.0 \mathrm{mg}$ - blue tablets imprinted with $\mathrm{SB}$ and 4894. REQUIPs is available in bottles in the pack size of 100 tablets. Full Product Monograph available to practitioners upon request.

GlaxoSmithKline Inc.

7333 Mississauga Road North

Mississauga, Ontario

L5N 6 L4

REQUPP is a registered trademark, used under license by GlaxoSmitt Kline inc.

Date of preparation: June 18,200

Date of revisions: March 31, 2004

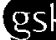

\section{KING MEDICAL}

\section{THE CANADIAN ELECTRODE PLACE}

- AMBU Blue Sensor - Neuroline

- CHALGREN Needles - Bar/Ring/Clip

- KENDALL Adhesive - NuTab

- KING MEDICAL Cables \& Adapters

- MAVIDON Lemon Skin Prep

- MEDTRONIC Mono/Conc. Needles

- PARKER LAB. Electrode Paste

- RADIANT Infrared Skin Thermometer

- 3M CANADA Micropore - Transpore

-D.O. WEAVER Ten20 - NuPrep

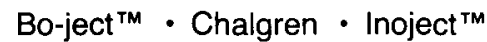

Large stock of Hypodermic Needles

Tel 905-833-3545

Fax 905-833-3543

E-mail: soren @kingmedical.com Web Site: www.kingmedical.com

King Medical Ltd.

145 Kingsworth Road

King City - Ontario L7B 1K1

\section{ADVERTISERS INDEX}

Acta Pharmacologica Sinica - A-16

Biogen Idec Inc.

Avonex - A-8, A-9, A-37, A-42

Event Planners Australia - 18th World

Congress of Neurology - A-17

GlaxoSmithkline

Imitrex - IBC, A-24, A-25

Requip - A-3, A-39, A-40

Janssen-Ortho

Reminyl - OBC, A-38

King Medical - A-40

Kyphon Inc. - A-14

Lundbeck

Ebixa - A-6, A-7, A-34, A-35, A-36

Keppra - A-12, A-13, A-26, A-27

Pfizer

Lipitor - A-11, A-32, A-33

Pregabalin (English) - A-15

Pregabalin (French) - A-19

Serono

Rebif - IFC, A-22, A-23

Teva Neuroscience

Copaxone (English) - A-5, A-28,

A-29

Copaxone (French) - A-20, A-30, A-31 A-41

Classified Ads - A-41, A-42, A-43, A-44 
seringue et un adaptateur de flacon stériles afin de prélever $1,1 \mathrm{~mL}$ du diluant fourni (eau stérile pour injection)

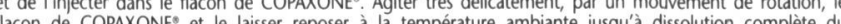

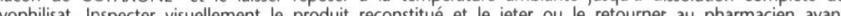
oplisation s'i recter visuele de lolution à l'aide d'une seringue stérile. Retirer l'adaptateur de flacon connecter une aiguille de calibre 27 et injecter la solution l'a être jetée (voir INFORMATION À L'INTENTION DU PATIENT, Produit reconstitué,

our obtenir les directives concernant la préparation et l'injection de COPAXONE" au moyen de la seringue RENSEIGNEMENTS PHARMACEUTIQUES

Substance médicamenteuse :

Substance médicamenteuse :

Nom propre:

Chimique:

Cescription :

L'acétate de glatiramère est le sel acétate de polypeptides synthétiques.

Lacelate de glatiramere est prepare par reaction chimique des derives actives de quatre acides aminés lacide proportion specilique. La fraction molaire de chave residu dacide aminé s'échelonne comme suit. L-Clu, de 0,129 à 0,153; L-Ala, de 0,392 a 0,462 ; L-Tyr, de 0,086 a

Formule Developpée : Poly $[$-Clids móculaire moyen du polypentide se situe entre 4700 et 11000 daltons, au moins 680

Poids moleculaire:
du matériel se situant entre 2500 et 22500 daltons.
Description Physique : Lyophilisat de couleur blanche à légèrement jaunâtre.

$\begin{array}{ll}\text { Soscription Physique : Lyophilisat de couleur blanche à légerement jaunatre. } \\ \text { Solubité: } & \text { Légerement soluble dans l'eau, insoluble dans l'acétone }\end{array}$

ph: Le pH d'une solution à $0,5 \% \mathrm{p} /$ d'acétate de glatiramère dans de l'eau se situe entre 5,5 et 8,0 Composition : COPAXONË (acétate de glatiramère pour injection) est un lyophilisat stérile destiné à l'injection sous-cutanée après reconstitution avec de l'eau stérile pour injection. Un flacon de lyophilisat renferme $20 \mathrm{mg}$ d'acétate de glatiramère et un surtitrage de $2 \mathrm{mg}$ pour tenir compte des pertes possibles pendant la reconstitution et le prélèvement ainsi que $40 \mathrm{mg}$ de mannitol. Un flacon d'eau stérile pour injection renferm $1,1 \mathrm{~mL}$ d'eau stérile pour injection et un surtitrage de $0,35 \mathrm{~mL}$ pour tenir compte des pertes possibles pendant la reconstitution et le prélèvement.

COPAXONE" (acétate de glatiramère injectable) est présenté en seringue préremplie à usage unique renfermant $20 \mathrm{mg} / 1,0 \mathrm{~mL}$ de solution stérile équivalant à la solution reconstituée de COPAXONE d'acétate de glatiramère et $40 \mathrm{mg}$ de mannitol dans de l'eau stérile pour injection).

Stabilité et conditions d'entreposage : Les flacons de lyophilisat de COPAXONE ${ }^{\circ}$ doivent être réfrigérés (entre 2 et $8^{\circ} \mathrm{C}$ ). $\mathrm{COPAXONE}^{\circ}$ peut également être conservé a la température ambiante (entre 15 et $30^{\circ} \mathrm{C}$ ) pendan un maximum de 14 jours. Les flacons de diluant (eau stérile pour injection) doivent être conservés à la température ambiante.

Les seringues preremplies de COPAXONE ${ }^{*}$ doivent être réfrigérées dès leur réception (entre 2 et $8^{\circ} \mathrm{C}$ ) NE PAS CONGELER

$S^{\prime} i l$ n'est pas possible de conserver les seringues préremplies de COPAXONE$^{-}$au réfrigérateur, elles peuvent être conservées à la température ambiante (entre 15 et $30^{\circ} \mathrm{C}$ ) pendant un maximum d'une semaine. Ne pas conserver les seringues préremplies de COPAXONE à la temperature ambiante pendant plus de sept jours. Remarque : ce médicament est sensible à la lumière, le protéger de la lumière lorsqu'on ne fait pas d'injection. Une seringue préremplie ne doit servir qu'une seule fois.

Reconstitution du lyophilisat : Pour reconstituer le lyophilisat de COPAXONE*, avant l'injection, utiliser un seringue et un adaptateur de flacon stériles afin de prélever le diluant fourni (eau stérile pour injection) et de linjecter dans le flacon de COPAXONE. Agiter tres delicatement, par un mouvement de rotation, le flacon de COPAXONE et le laisser reposer à la temperature ambiante jusqu a dissolution complète du lyophilisat. Inspecter visuellement le produit reconstitue et le jeter ou le retourner au pharmacien avant l'utilisation s'i renferme des particules. Une fois le produit complètement dissous, prélever $1,0 \mathrm{~mL}$ de la solution à l'aid d'une seringue stérile. Retirer l'adaptateur de flacon, connecter une aiguille de calibre 27 et injecter la solution par voie sous-cutanee. Un flacon ne convient qua a une seule utilisation; toute portion inutilisée dor etre jetee. La solution reconstituee ne doit pas etre conservee plus de huit heures a la temperature ambiante. Produits parentéraux : COPAXONE" ne doit être reconstitué qu'avec le diluant fourni (eau stérile pour injection).

\begin{tabular}{|c|c|c|c|}
\hline $\begin{array}{c}\text { Format du } \\
\text { flacon }\end{array}$ & $\begin{array}{c}\text { Volume de diluant à } \\
\text { ajouter }\end{array}$ & $\begin{array}{c}\text { Volume à } \\
\text { injecter }\end{array}$ & $\begin{array}{c}\text { Concentration } \\
\text { nominale par mL }\end{array}$ \\
\hline $2 \mathrm{~mL}$ & $1,1 \mathrm{~mL}$ & $1,0 \mathrm{~mL}$ & $20 \mathrm{mg}$ \\
\hline
\end{tabular}

\section{PRÉSENTATION}

COPAXONE $^{\circ}$ (acétate de glatiramère pour injection) est offert sous la forme d'une dose de $20 \mathrm{mg}$ de lyophilisat stérile d'acétate de glatiramere avec du mannitol, le produit étant conditionné dans des flacons unidoses de $2 \mathrm{~mL}$ de couleur ambre. Un deuxième flacon renfermant 1,1 mL de diluant (eau stérile pour injection) et un surtitrage de $0,35 \mathrm{~mL}$ accompagne chaque flacon de médicament et est inclus dans la trousse d'auto-administration. COPAXONE ${ }^{\star}$ (acétate de glatiramère pour injection) est offert en emballages de 32 flacons de couleur ambre renfermant le lyophilisat stérile destiné à l'injection sous-cutanée. Le diluant (eau stérile pour injection) accompagnant COPAXONE ${ }^{*}$ est offert en emballages de 32 flacons transparents qui son inclus dans la trousse d'auto-administration.

COPAXONE (acétate de glatiramère injectable) est présenté en seringues préremplies à usage unique renfermant $20 \mathrm{mg} / 1.0 \mathrm{~mL}$ de solution stérile équivalant à la solution reconstituée de COPAXONE" COPAXONE" (acétate de glatiramère injectable) est offert en emballages de 30 seringues en verre préremplies à usage unique $20 \mathrm{mg} / 1,0 \mathrm{~mL}$ ), accompagnées de 33 tampons d'alcool.

Monographie fournie sur demande.

Bibliographie :

1. Monographie de COPAXONE* (acétate de glatiramère), Teva Neuroscience.
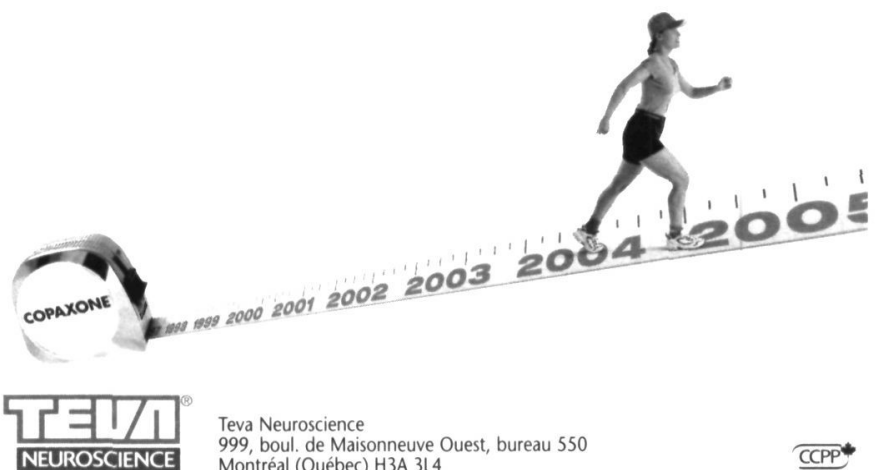

Teva Neuroscience

999, boul de Maisonneuve Ouest, bureau 550

Montréal (Québec) H3A 3L4

Continué sur page 31

Voir page A-20, A-30, A-31

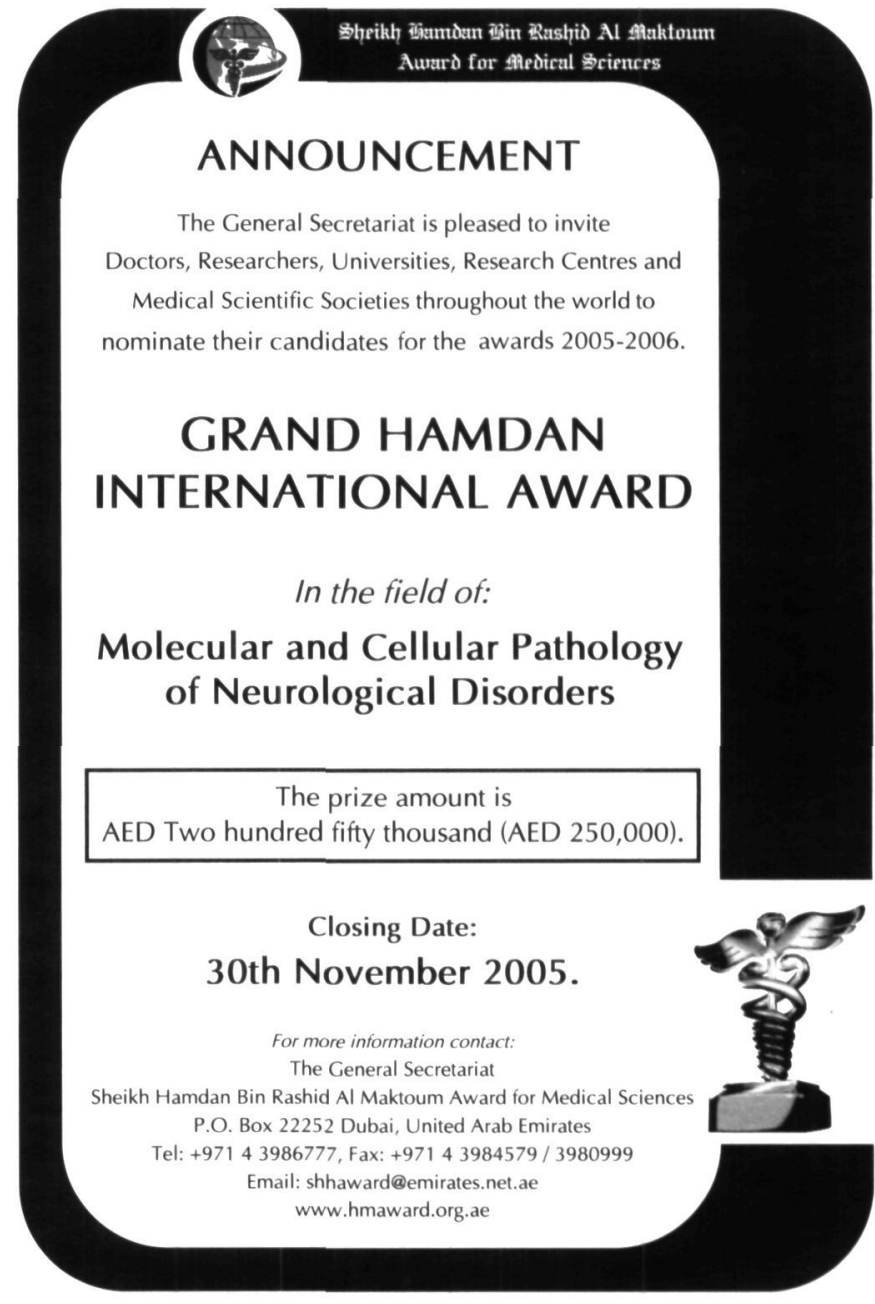

\section{BUILD YOUR PRACTICE...}

\section{where the future of medicine lives.}

\section{NEUROLOGISTS - Wisconsin}

Marshfield Clinic Neurosciences Division includes 25 neurologists, 6 neurosurgeons, 3 neuroradiologists and 3 neuropsychologists. Clinical subspecialties are represented in cerebrovascular disease, epilepsy, sleep, dementia, movement disorders, neuromuscular disease, pediatric neurology and neuroimmunology. Research opportunities abound but are not prerequisite. The work atmosphere supports sub-specialty practice development, collaborative effort and quality care. We have the following practice opportunities available at our Marshfield Center in Marshfield, Wisconsin:

\section{- Medical Director of the Movement Disorders Center \\ - BC/BE Neurologist w/fellowship training or expertise in Headache Neurology}

\section{- BC/BE Epilepsy Neurologist}

- BC/BE Pediatric Neurologist

We offer a generous salary and excellent compensation package including: Malpractice, health, dental, life and disability insurance; $\$ 5,500$ Education Allowance with 10 days of CME time; generous employer contributed retirement and $401 \mathrm{~K}$ plan; four weeks vacation 1 st year; up to $\$ 10,000$ relocation allowance

Marshfield Clinic is a physician directed organization with over 700 physicians practicing in over 80 medical specialties and subspecialties. There are over 40 regional centers serving north central and western Wisconsin. The main campus includes a tertiary clinical center, research center and 504-bed tertiary hospital. The work atmosphere is academic, collegial and informal. Send your curriculum vitae in

confidence, to: Sandy Heeg. Physician Recruiter, Marshfield Clinic, 1000 North Oak

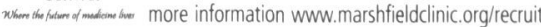

Marshfield Clinic is an Affirmative Action:Equal Opportunity employer that values diversity Minontes females

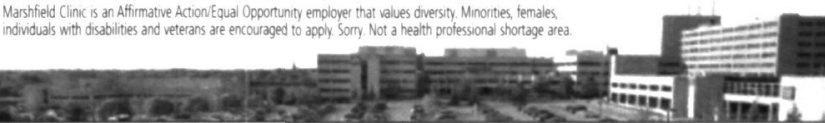


Table 1 (continued) Adverse Events and Selected Laboratory Abnormalities in the Placebo-Controlled Study of Relapsing MS

\begin{tabular}{lcc}
\hline Adverse Event & $\begin{array}{c}\text { Placebo } \\
\text { (N }=143)\end{array}$ & $\begin{array}{c}\text { AVONEX } \\
(\mathrm{N}=158)\end{array}$ \\
\hline
\end{tabular}

\section{Abdominal pain}

Chest pain

Injection site reaction

Malaise

Injection site inflammation

Hypersensitivity reaction

Ovarian cyst

Ecchymosis injection site

Cardiovascular System

Syncope

Vasodilation

Digestive System

Nausea

Diarrhea

Dyspepsia

Anorexia

Hemic and Lymphatic System

Anemia*

Eosinophils $\geq 10 \%$

$\mathrm{HCT}(\%) \leq 32$ (temales) or $\leq 37$ (males)

Metabolic and Nutritional Disorders

SGOT $\geq 3 \times$ ULN

Musculoskeletal System

Muscle ache*

Arthralgia

Nervous System

Sleep difficult

Dizziness

Muscle spasm

Suicidal tendency

Seizure

Speech disorder

Ataxia

Respiratory System

Jpper respiratory tract infection

Sinusitis

Sinusitis

Skin and Appendages

kin and

Urticaria

Nevus

\begin{tabular}{|c|c|}
\hline $6 \%$ & $9 \%$ \\
\hline $4 \%$ & $6 \%$ \\
\hline $1 \%$ & $4 \%$ \\
\hline $3 \%$ & $4 \%$ \\
\hline $0 \%$ & $3 \%$ \\
\hline $0 \%$ & $3 \%$ \\
\hline $0 \%$ & $3 \%$ \\
\hline $1 \%$ & $2 \%$ \\
\hline $2 \%$ & $4 \%$ \\
\hline $1 \%$ & $4 \%$ \\
\hline 23\% & $33 \%$ \\
\hline $10 \%$ & $16 \%$ \\
\hline $7 \%$ & $11 \%$ \\
\hline $6 \%$ & $7 \%$ \\
\hline $3 \%$ & $8 \%$ \\
\hline $4 \%$ & $5 \%$ \\
\hline $1 \%$ & $3 \%$ \\
\hline $1 \%$ & $3 \%$ \\
\hline $15 \%$ & $34 \%$ \\
\hline $5 \%$ & $9 \%$ \\
\hline $16 \%$ & $19 \%$ \\
\hline $3 \%$ & $15 \%$ \\
\hline $6 \%$ & $7 \%$ \\
\hline $1 \%$ & $4 \%$ \\
\hline $0 \%$ & $3 \%$ \\
\hline $0 \%$ & $3 \%$ \\
\hline $0 \%$ & $2 \%$ \\
\hline $28 \%$ & $31 \%$ \\
\hline $7 \%$ & $18 \%$ \\
\hline $3 \%$ & $6 \%$ \\
\hline $2 \%$ & $5 \%$ \\
\hline $1 \%$ & $4 \%$ \\
\hline $0 \%$ & $3 \%$ \\
\hline
\end{tabular}

Table I (continued)
$\begin{aligned} & \text { Adverse Events and Selected Laboratory Abnormalities } \\
& \text { in the Placebo-Controlled Study of Relapsing MS }\end{aligned}$
\begin{tabular}{lcc}
\hline Pdverse Event & Placebo & AVONEX \\
& $(\mathrm{N}=143)$ & $(\mathrm{N}=158)$ \\
\hline
\end{tabular}

\section{Herpes zoster}

Herpes simplex

Special Senses

Otitis media

Hearing decreased

Urogenital

Vaginitis

Significantly associated with AVONEX treatment $(p \leq 0.05)$

$2 \%$

$3 \%$

$2 \%$

$5 \%$

$0 \% \quad 3 \%$

$3 \%$

$4 \%$

\section{Post-Marketing Experience}

Anaphylaxis and other allergic reactions have been reported in patients using

AVONEX' (see WARNINGS: Anaphylaxis). Decreased peripheral blood

counts have been reported in patients using AVONEX (see WARNINGS

Decreased Peripheral Blood Counts). Seizures, cardiovascular adverse events,

and autoimmune disorders also have been reported in association with the

USe of AVONEX (see PRECAUTIONS)

Single Demyelinating Event

The adverse events observed in the placebo-controlled study of patients with a single demyelinating event were similar to those observed in the placebo-controlled study of relapsing MS patients. Patients in this trial $(\mathrm{N}=193)$ initiated AVONEX treatment while on oral prednisone, which was used to treat the initial demyelinating event. The most common advers events associated with AVONEX $(p \leq 0.05)$ during the first 6 months of events associated with AVONEX $(P \leq 0.05)$ during the first 6 months of
treatment were flu-like syndrome (AVONEX $: 39 \%$, placebo: $22 \%$ ), fever (AVONEX: $17 \%$, placebo: $6 \%$ ), and chills (AVONEX: $17 \%$, placebo: $3 \%$ ), A higher proportion of patients treated with AVONEX $(20 \%)$ experienced depression, as compared with placebo (13\%) $(p=0.05)$ (see WARNINGS).

\section{DOSAGE AND ADMINISTRATION}

The recommended dosage of AVONEX ${ }^{8}$ (Interferon beta-1a) is $30 \mathrm{mcg}$ injected intramuscularly once a week. AVONEX is intended for use under the guidance and supervision of a physician. Patients may self-inject only if their physician determines that it is appropriate and with medical follow-up, as necessary. after proper training in IM injection technique.

Before initiating a patient on AVONEX therapy, please note the following CONTRAINDICATIONS

- AVONEX is contraindicated in patients with a known hypersensitivity to natural or recombinant interferon beta, albumin (human), or any other component of the formulation. Anaphylaxis has been observed with the use of AVONEX
Please also review the WARNINGS and PRECAUTIONS sections and ensure appropriate monitoring of patients with depression, hepatic dysfunction, a history of seizures, cardiac disease, thyroid dysfunction, myelosuppression, and female patients of child-bearing potential.

Patients should be advised of the side-effects of AVONEX ${ }^{s}$ and instructed on the use of aseptic technique when administering AVONEX ${ }^{3}$. The AVONEX Patient Leaflet should be carefully reviewed with all patients, and patients

should be educated on self-care and advised to keep the Leaflet for continued reference during AVONEX ${ }^{\mathbb{B}}$ therapy

\section{AVAILABILITY OF DOSAGE FORMS}

AVONEX (Interferon beta-1a) is available as:

Package (Administration Pack) containing 4 Administration Dose Packs (each containing one vial of AVONEX ${ }^{*}$, one $10 \mathrm{~mL}(10 \mathrm{cc})$ diluent vial, two alcohol wipes, one 3cc syringe, one Micro Pin ${ }^{\infty}$, one needle, one adhesive bandage one gauze pad)

Product Monograph available upon request.

\section{REFERENCES}

1. Galetta SL, Markowitz C, Lee AG. Immunomodulatory agents for the treatment of relapsing multiple sclerosis. Arch Intern Med 2002; 162:2161-2169.

2. Bertolotto A, Malucchi S, Sala A, et al. Differential effects of three interferon betas on neutralizing antibodies in patients with multiple sclerosis: a follow-up study in an independent laboratory. J Neurol Neurosurg Psychiatry 2002:73:148-153

3. Giovannoni G, Munschauer FE, Deisenhammer F. Neutralizing antibodies to interferon beta during the treatment of multiple sclerosis. J Neurol Neurosurg Psychiatry 2002;73;465-469

4. Rudick RA, Simonian NA, Alam JA. Incidence and significance of neutralizing antibodies to interferon beta-1a in multiple sclerosis. Neurology 1998:50:1266-1272.

5 AVONEX Product Monograph, 2003

\section{biogen idec}

3 Robert Speck Parkway, Suite 300, Mississauga, Ontario L4Z 2 G5 (c) 2004 Biogen Idec Canada Inc. All rights reserved

Biogen Idec Canada Inc. is a trademark of Biogen Idec MA Inc AVONEX is a registered trademark of Biogen Idec MA Inc. Micro $\mathrm{Pin}^{\mathrm{B}}$ is a registered trademark of $\mathrm{B}$. Braun Medical Inc.

\section{Canadian Headache Society GlaxoSmithKline Headache Fellowship}

This fellowship has been created to support research and clinical training in the field of headache in Canada. The fellowship is valued at $\$ 50,000$ and will be awarded for a one year period. The award will be tenable as of July 1st, 2006.

Candidates must have an MD or $\mathrm{PhD}$ degree. Preference will be given to those who have completed a specialty program approved by the Royal College of Physicians and Surgeons of Canada, but others are welcome to apply and will be considered. Applications must contain a research proposal relevant to headache. The proposed research must be done in Canada.

Applications must be received by December 31, 2005.

Further details and instructions for applicants may be obtained from:

Canadian Headache Society

Dr. Werner Becker, President

12 Flr, Clinical Neurosciences, Foothills Hospital

1403 - 29th St. NW Calgary, AB T2N 2T9

Tel: (403) 944-4240; Fax: (403) 283-2270

Email: wbecker@ucalgary.ca

\section{Société canadienne des céphalées Bourse de rechereche dlinique en céphalée}

Cette bourse a été cré afin de soutenir la recherche clinique dans le domaine de la céphalée au Canada. D'une valeur de $50000 \$$, la bourse sera attribuée pour une période d'un an et prendra effet le ler juillet 2006.

Les candidats doivent être titulaire d'un diplôme de médecine ou d'un doctorat de 3ième cycle. Une préférence sera donnée à ceux qui sont inscrits à un programme de spécialité approuvé par le Collège royal des médecins et chirurgiens du Canada. Tous les autres canadidats seront les bienvenus et leurs demandes seront considérés. Les demandes doivent contenir un projet de recherche dans le domaine de la céphalée. La recherche proposé doit être entreprise au Canada.

La date limite de réception des demandes de bourse : le 31er decembre 2005.

Pour obtenir plus de précisions, écrire à l'adresse suivante:

Canadian Headache Society

Dr. Werner Becker, Président

12 Flr, Clinical Neurosciences, Foothills Hospital 1403 - 29th St. NW Calgary, AB T2N 2T9

Tel: (403) 944-4240; Fax: (403) 283-2270

Email: wbecker@ucalgary.ca 


\section{IIII Manulife Financial}

\section{ThinkFirst Foundation of Canada and Manulife Financial Present}

\section{CONCUSSION ROAD SHOW 2005 - 2006!}

This program is designed to enhance concussion education and

\section{awareness for}

physicians, nurses, therapists, athlefes, coaches, trainers, psychologists, teachers, parents, media and the public.

When: Saturday, September $24^{\text {th }}, 2005$

Time: 8:30 a.m. - 11:30 a.m.

Where: Imax Theatre, Science World

\section{Quebec St. \\ Vancouver, $\mathrm{BC}$}

\section{Speakers Include}

Dr. Karen Johnston, MD, PhD, FRCSC, FACS

Dr. Johnston is a neurosurgeon whose specialty is in the field of brain injury. Her clinical and research practices focus on sport head injury and concussions in athletes. She is an international neurosurgical consultant to professional and amateur sporting groups.

\section{Dr. Jamie Kissick, MD, Dip. Sport Med}

Dr. Kissick is a sport medicine physician who has experience as Head Team Physician for the NHL team, the Ottawa Senators from 1992-2002, and is currently the Team Physician for the CFL team, the Ottawa Renegades.

\section{Local Speakers}

\section{Mr. Carl Peterson, B.P.E., B.Sc. (PT)}

Mr. Petersen is an Internationally recognized physical therapist, and has spent over 18 years as the physiotherapist and fitness Coach for the Canadian Alpine Ski Team. He lends his expertise on concussion and head injury from a physiotherapist/trainer perspective.

\section{Program Chair}

\section{Dr. Brian Hunt, MD, Neurosurgery}

To Register for this FREE Concussion Education Program, please contact Mr. Larry Morrison by phone and/or email at:

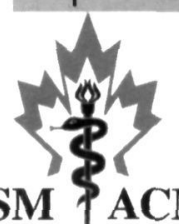

604-512-2991 or vcsregistration@soragroup.com 


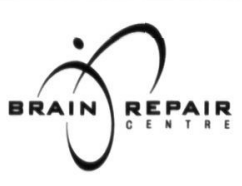

The Division of Neurosurgery at Dalhousie University is offering a one year Clinical Fellowship in Stereotactic \& Functional Neurosurgery. Functional neurosurgical procedures for Atlantic Canada (population 2,500,000) are performed at the QEII Health Sciences Center/Dalhousie University. The Division of Neurosurgery is affiliated with the multimillion dollar Brain Repair Centre, with facilities ranging from basic science laboratories to a human 4T MRI.

Fellows will participate in the evaluation and treatment of patients with a broad range of functional neurosurgical disorders including:

$$
\begin{array}{ll}
\text { - } & \text { Movement disorders } \\
\text { - } & \text { Epilepsy } \\
\text { - } & \text { Spasticity } \\
\text { - } & \text { Angina }
\end{array}
$$

Fellows will have training in different techniques including:

- Deep brain stimulation, with and without microelectrode recording

- Motor Cortex Stimulation

- Spinal cord stimulation

- Intrathecal therapy

- Ablative procedures

- Selective mesial temporal resections

- Extratemporal resections for epilepsy

- Neurotransplantation

- Vagus nerve stimulation

Fellows are expected to be involved in clinical research projects. Opportunities for those interested in basic science research are also available. Candidates must have completed their neurosurgical training and be eligible for licensure in Nova Scotia, This position is to commence July 01,2006 . Interested candidates should send three letters of reference along with their cover letter outlining why they wish to study stereotactic and functional neurosurgery, by date September $01,2006$. To

Rob Brownstone, MD. PhD, FRCSC

Division of Neurosurgery, QEII Health Sciences Center 3816-1796 Summer Street, Halifax, NS B3H3A7

Phone: (902)473-6850 Fax: (902) 473-6852

Email: rob.brownstone@dal.ca

Websites: www.neurosurgery.medicine.dal.ca www.brainrepair.ca www.neuraltransplantation.dal.ca www.motorcontrol.med.dal.ca

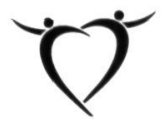

Capital Health

\section{Neurologist Saint John, New Brunswick}

The Department of Medicine at Atlantic Health Sciences Corporation (AHSC) invites applications for a Neurologist to join two established Neurologists in Saint John. AHSC is the largest multi-facility regional health authority in New Brunswick and serves a population of 200,000 in the southern part of the province. The flagship hospital, the Saint John Regional Hospital, has 23 areas of specialty medicine and surgery, including neurosurgery, and is supported by a vast array of research, education, health promotion activities and community partnership.

This is an excellent position for an individual with an interest in a varied clinical practice with opportunities for clinical trial research and self generated projects supported by an active research department. University affiliation and teaching responsibilities at both the undergraduate and graduate level exist.

Saint John is situated in the picturesque Bay of Fundy and is located on one of the finest inland waterways in North America. Saint John offers numerous social and cultural facilities as well as recreational opportunities including boating, yachting, winter sports, golf and fishing. Being the only official bilingual province, there is access to both English and French school systems. The Saint John campus of the University of New Brunswick is adjacent to the Saint John Regional Hospital and offers a wide variety of undergraduate and postgraduate programs.

Applicants must be eligible for licensure in the Province of New Brunswick and hold specialty certification in Neurology from the Royal College of Physicians and Surgeons of Canada or equivalent certification and experience. The successful candidate may be eligible for an academic appointment.

Please send CV's to:

Dr. Peter Bailey, Division of Neurology, Atlantic Health Sciences Corporation P.0. Box 2100, Saint John, NB E2L 4L2 (E-mail): pbailey@nbnet.nb.ca

We thank you for your interest, however. only those chosen for interview will be contacted.

Visit us at www.ahsc.health.nb.ca Atlantic Health Sciences Corporation adheres to a Healthy Air Policy.

Our properties are smoke-free and we encourage the use of scent-reduced products.

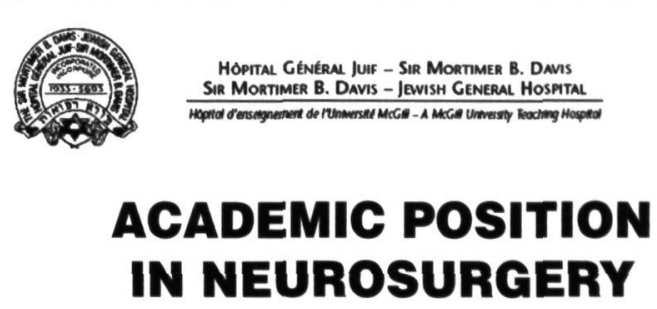

The Division of Neurosurgery, Department of Neurological Sciences, Sir Mortimer B. Davis - Jewish General Hospital is presently seeking a second full-time position due to relocation in another province. The full-time neurosurgeon should be licensed in Quebec and should obtain the certification of the Office de la langue franćaise. Subspecialty fellowship in spine instrumentation and/or neuro-oncology is mandatory.

The position implies a forfeitary remuneration (remuneration mixte) according to the agreement between the Quebec Federation of Specialists and the Regie de l'Assurance Maladie du Quebec.

The position will be available starting September 1, 2005 and includes one half time secretary and a free office space. Candidates should send their CV to:

\section{Dr. Gérard Mohr}

Chief, Division of Neurosurgery

SMBD- Jewish General Hospital

E-006

3755 Cote St. Catherine Rd.

Montreal, Qc H3T 1E2 


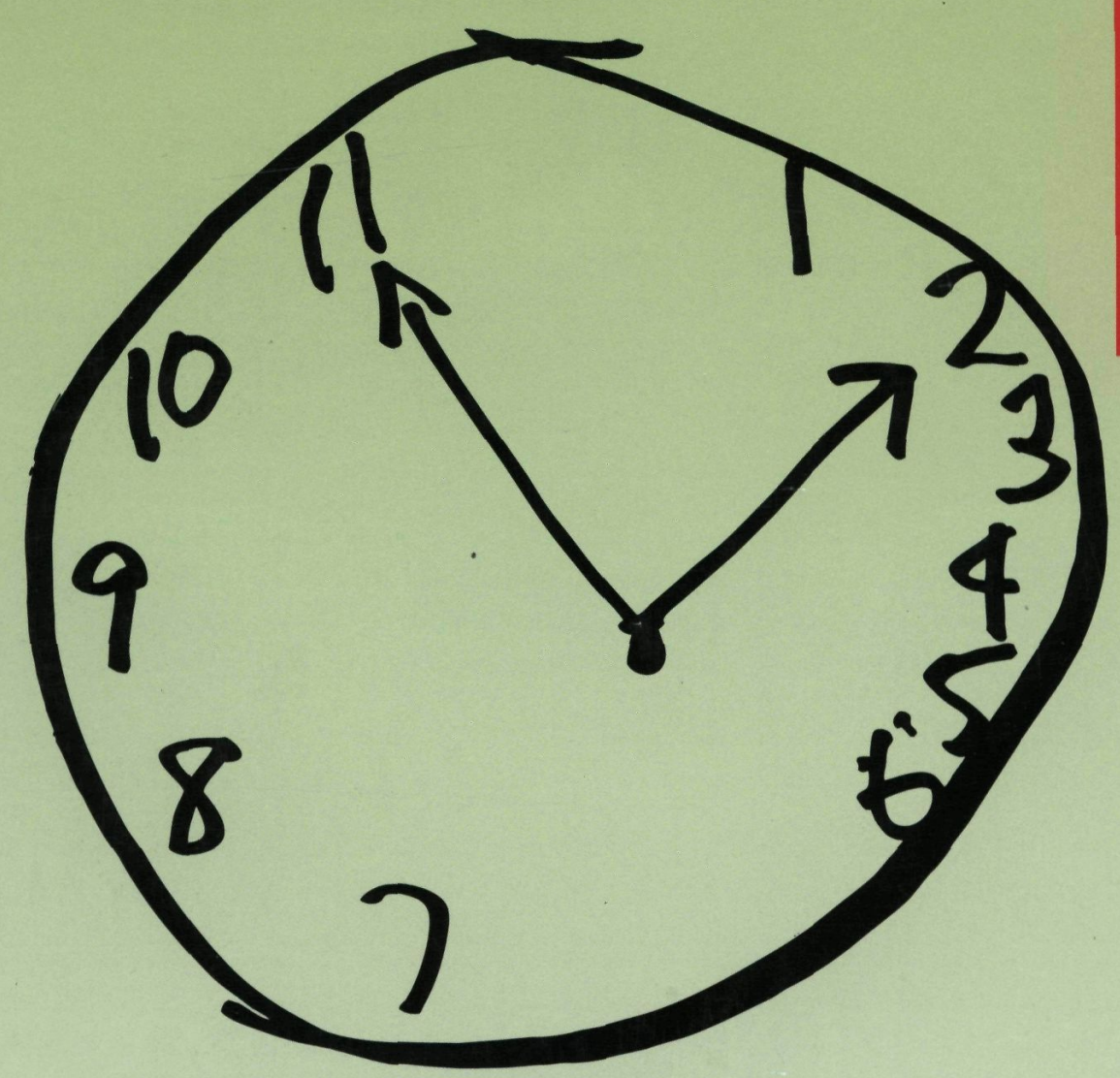

\section{NEW Once-a-Day REMINYL ER}

\section{It's Time To Take Another Look at REMINYL.}

REMINYL is now available in a once-a-day formulation: REMINYL ER. Consider new REMINYL ER as initial treatment in AD.

REMINYL ER (galantamine hydrobromide) is indicated for the symptomatic treatment of patients with mild to moderate dementia of the Alzheimer's type. REMINYL ER has not been studied in controlled clinical trials for longer than 6 months.

The most common side effects (vs. placebo) in a clinical trial were nausea ( $17 \%$ vs. $5 \%)$, dizziness
( $10 \%$ vs. $4 \%)$, injury ( $8 \%$ vs. $6 \%)$ and headache ( $8 \%$ vs. $6 \%$ ). For patients who experienced adverse events, the majority occurred during the dose-escalation phase.

There is no evidence that galantamine alters the course of the underlying dementing process.

REFERENCE: 1. REMINYL* (galantamine hydrobromide tablets), REMINYL* ER (galantamine hydrobromide extended-release capsules) Product Monograph, JANSSEN-ORTHO inc., April 8, 2005.

(C) 2005 JANSSEN-ORTHO Inc. * All trademark rights used under license

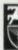
JANSSEN-ORTHO 19 Green Belt Drive, Toronto Ontario, Canada M3C 119 ROJA050820E
RED PAAB* galantamine $\mathrm{HBr}$

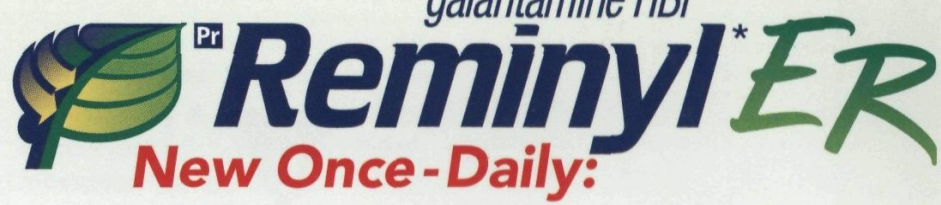

It may change your mind.

For brief prescribing information see page A-38 


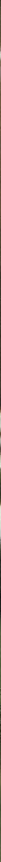

\section{INTRODUCING NEW IMITREX DF" ITS AIM IS STILL SPEED TO ZERO PAIN ${ }^{\mathrm{m}}$}

New IMITREX DF ${ }^{\mathrm{TM}}$ tablets are designed to promote tablet disintegration and dispersion."

In fact, in vitro dissolution showed that nearly $100 \%$ of the sumatriptan was dissolved within 2 minutes ${ }^{1+}$ ('Clinical significance not yet established).

With IMITREX DF ${ }^{\mathrm{TM}} 100 \mathrm{mg}$ tablets, close to $45 \%$ of attacks were reduced to ZERO PAIN ${ }^{\mathrm{TM} * *}$ at 1 hour; $66 \%$ reduced to ZERO PAIN ${ }^{\mathrm{TM}}$ at 2 hours when patients were instructed to initiate migraine treatment during the mild pain phase ${ }^{2 \Delta z}$

IMITREX DF ${ }^{\mathrm{TM}}$ tablets were shown to be bioequivalent to conventional IMITREX ${ }^{\circledR}$ tablets $^{1 B \otimes}$ ( $\diamond$ Comparative clinical significance is unknown).

IMITREX DF ${ }^{\mathrm{IM}}$ (sumatriptan succinate) is a selective $5-\mathrm{HT}_{1}$ receptor agonist indicated for the acute treatment of migraine attacks with or without aura. ${ }^{3}$ IMITREX DF ${ }^{\mathrm{TM}}$ is not indicated for prophylactic therapy of migraine, or for the management of hemiplegic, basilar, or ophthalmoplegic migraine. Safety and efficacy have not been established for cluster headache. ${ }^{3}$

IMITREX DF ${ }^{\mathrm{TM}}$ is contraindicated in patients with history, symptoms or signs of ischemic cardiac, cerebrovascular, or peripheral vascular syndromes, valvular heart disease or cardiac arrhythmias. In addition, patients with other significant underlying cardiovascular diæeases should not receive IMITREX DF ${ }^{\mathrm{TM}}$. IMITREX DF ${ }^{\mathrm{TM}}$ is also contraindicated in patients with uncontrolled or severe hypertension.

The most common adverse events with IMITREX DF ${ }^{\mathrm{TM}} 100 \mathrm{mg}$ tablets included: nausea (11.0\% vs 5.8\% placebo), malaise/fatigue (9.5\% vs $5.1 \%$ placebo), sensations (body regions unspecified) ( $9.0 \%$ vs $4.5 \%$ placebo). ${ }^{3}$

"Dissolution testing was performed using USP II apparatus in $0.01 \mathrm{M} \mathrm{HCL} \mathrm{(aq)} \mathrm{at} 30 \mathrm{rpm}$.'

$\Delta 2$-hour post-dose time point was the primary endpoint.

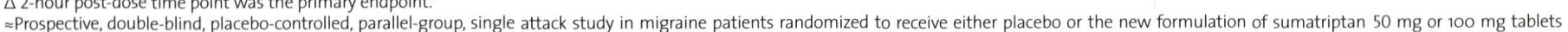

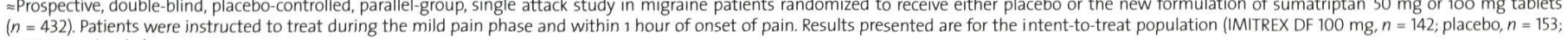
$p<0.001$ vs placebo):

"ZZERO PAIN ${ }^{m}$ refers to complete relief of pain or "o" (zero) on a 4-point scale where $0=$ no pain, $1=$ mild pain, $2=$ moderate pain and $3=$ severe pain.

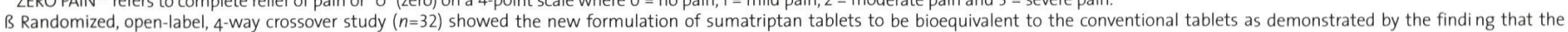
$90 \%$ confidence intervals for sumatriptan $A \cup C_{0 . \infty}, A C_{0 . t}$ and $C_{\max }$ fell within the predetermined bounds defining bioequivalence $(0.80$ to 1.25$)$ for both $50 \mathrm{mg}$ and $100 \mathrm{mg}$ doses. 